UNIVERSIDADE DE SÃO PAULO

ESCOLA DE ENFERMAGEM

JANAÍNA FERRO PEREIRA

SIGNIFICADO DE AMAMENTAR PARA MULHERES RESIDENTES EM UMA COMUNIDADE DE ALTA VULNERABILIDADE SOCIAL NO INTERIOR DE ALAGOAS

SÃO PAULO

2014 
SIGNIFICADO DE AMAMENTAR PARA MULHERES

RESIDENTES EM UMA COMUNIDADE DE ALTA

VULNERABILIDADE SOCIAL NO INTERIOR DE

ALAGOAS

Tese apresentada ao Programa Interunidades de Doutoramento em Enfermagem da Escola de Enfermagem da Universidade de São Paulo e Escola de Enfermagem de Ribeirão Preto da Universidade de São Paulo - Curso Doutorado Interinstitucional entre a Universidade de São Paulo e Universidade Federal de Sergipe, tendo como associada a Universidade Federal de Alagoas, para obtenção do título de Doutor em Ciências.

Versão Corrigida

Área de Concentração: Sociedade, Saúde e Enfermagem

Orientadora: Prof. ${ }^{a}$ Dr. ${ }^{a}$ Isilia Aparecida Silva

\section{SÃO PAULO}


AUTORIZO A REPRODUÇÃO E DIVULGAÇÃO TOTAL OU PARCIAL DESTE TRABALHO, POR QUALQUER MEIO CONVENCIONAL OU ELETRÔNICO, PARA FINS DE ESTUDO E PESQUISA, DESDE QUE CITADA A FONTE.

Assinatura:

Data:

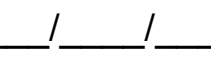

\author{
Catalogação na Publicação (CIP) \\ Biblioteca "Wanda de Aguiar Horta" \\ Escola de Enfermagem da Universidade de São Paulo
}

Pereira, Janaína Ferro

Significado de amamentar para mulheres residentes em uma comunidade de alta vulnerabilidade social no interior de Alagoas/ Janaína Ferro Pereira. -- São Paulo, 2014.

$189 \mathrm{p}$.

Tese (Doutorado) - Escola de Enfermagem da Universidade de São Paulo.

Orientadora: Profa. Dra. Isilia Aparecida Silva

Área de concentração: Enfermagem

1. Aleitamento materno 2. Pobreza 3. Saúde da mulher 4. Discurso do sujeito coletivo I. Título. 


\section{FOLHA DE APROVAÇÃO}

\section{Nome: Janaina Ferro Pereira}

Título: Significado de amamentar para mulheres residentes em uma comunidade de alta vulnerabilidade social no interior de alagoas.

Tese apresentada ao Programa Interunidades de Doutoramento em Enfermagem - EE-EERP/USP, para obtenção do titulo de Doutor em enfermagem.

Aprovada em:

Banca Examinadora.

Prof.Dr. Instituição:

Julgamento: Assinatura:

Prof.Dr. Instituição:

Julgamento: Assinatura:

Prof.Dr. Instituição:

Julgamento: Assinatura:

Prof.Dr. Instituição:

Julgamento: Assinatura:

Prof.Dr. Instituição: Assinatura: 


\section{DEDICATÓRIA}

A minha mãe Zezé, por todo seu amor, sempre ao meu lado, em todos os momentos. Você é o meu porto seguro. Com você por perto tudo se torna possível.

Ao meu pai José, que do seu jeito particular, torcia por meu sucesso. Aos meus irmãos Juliana e João Bruno, que estavam ao lado de meus filhos nas minhas ausências.

Ao meu companheiro Marcos, sempre de forma paciente tem me ensinado como viver de forma mais tranquila.

Aos meus filhos, Pedro e Guilherme, cada um, ao seu modo, me incentivou a prosseguir. 
À minha sábia orientadora, Prof. ${ }^{a}$ Dr. ${ }^{a}$ Isilia Aparecida Silva, que conduziu de forma brilhante todo o processo de minha orientação.

Ao Prof. Dr. Irinaldo Diniz Basílio Júnior, à Prof. ${ }^{a}$ Dr. ${ }^{a}$ Regina Santos, e à Prof. ${ }^{a}$ Dr. $^{\mathrm{a}}$ Renata Mann que batalharam para a implantação e conduziram este Doutorado InterinstitucionalDINTER.

Às minhas companheiras do DINTER, com quem dividi vários momentos de minha vida, durante essa jornada, em especial à Ana Paula Nogueira, minha amiga e companheira de todas as horas.

Aos amigos professores da UFAL/CAMPUS ARAPIRACA, que, mesmo estando sobrecarregados, entenderam a necessidade de meu afastamento. Em especial à Francisca Maria Nunes Silva, minha admirável e companheira amiga de tantos anos. E às alunas Natanna W. F. dos Santos, Fernanda Pinto e Edcherly Ferreira.

Às mulheres da Comunidade Mangabeiras, representada por sua líder comunitária D. Lourdes, que sempre me recebeu bem e contribuiu em todo processo de coleta de dados.

A todos os mestres e funcionários da Escola de Enfermagem da USP - EEUSP, pela oportunidade concedida para a realização deste curso.

À Coordenação de Aperfeiçoamento de Pessoal de Nível Superior CAPES, edital 005/2009 Ação Novas Fronteiras da CAPES/MEC 
"Que nunca te falte um sonho pelo qual lutar, um projeto para realizar, algo para aprender, um lugar para onde ir, e alguém a quem amar".

(Vanessa Pimentel) 


\section{RESUMO}

PEREIRA, JF. Significado de amamentar para mulheres residentes em uma comunidade de alta vulnerabilidade social no interior de Alagoas. 2014. 189f. TESE (Doutorado) - Escola de Enfermagem, Universidade Federal de São Paulo, São Paulo, 2014.

O contexto social de pobreza exige práticas efetivas para a garantia de qualidade e segurança alimentar de crianças, entre elas a amamentação. No entanto, os índices de aleitamento materno entre populações de baixa renda não se mostra promissor, indicando a necessidade de se conhecer como se dá o processo de prática do aleitamento materno em comunidades que vivenciam a pobreza. Este estudo teve os objetivos: Compreender o significado de amamentar e como se desenvolve a prática de amamentação da mulher moradora da Comunidade Mangabeira, próxima ao aterro sanitário da cidade de Arapiraca-Alagoas. Adotou-se o método qualitativo, tendo como referencial teórico o Interacionismo Simbólico, Modelo Pesando Riscos e Benefícios; a estratégia do DSC para organização dos dados. Foram coletados dados quantitativos para caracterização biológica e social da mulher e sobre a prática de amamentação, que ampliaram, de forma descritiva, o entendimento da experiência de amamentação das 35 mulheres participantes do estudo, residentes na comunidade, que sobrevivem da catação de material reciclado e que tinham tido a experiência de amamentar pelo menos um de seus filhos. Os resultados mostram que elas têm baixa escolaridade e renda não superior a dois salários mínimos, a média de idade é 36,2 anos, com taxa de fecundidade de 4,2 filhos por mulher. Apenas 58,3\% das mulheres referem ter amamentado exclusivamente seus filhos e a mediana de AM é 22,3 meses, sendo maior que a mediana para os estados do Nordeste. Com base nos dados qualitativos, emergiram três temas explicativos da experiência de amamentar: Determinada a amamentar: do saber à necessidade; Prática de amamentar: cuidado familiar e coletivo; Fragilidades na valorização da amamentação. A amamentação é utilizada como recurso contra a fome do recém-nascido, pois dificilmente as mulheres conseguem adquirir alimentos de outras fontes, mas ao mesmo tempo o aleitamento materno mostra uma prática frágil do pondo de vista das escolhas dessas mulheres, podendo ser substituído por outro alimento quando é possível obtê-lo. Essa prática está sujeita à condição e disponibilidade física e emocional da mulher para amamentar, apesar de reconhecida a sua importância para suprir a necessidade da criança. Não sendo valorizada pela sua importância em si, a amamentação é vista como uma experiência normal, previsível e habitual, a ser incorporada no seu cotidiano enquanto for possível ou necessária. O significado da amamentação para essas mulheres mostra-se como sendo uma experiência nem boa, nem ruim, mas apenas normal. Considerações finais: Além de medidas sociais de distribuição de benefícios 
para as famílias carentes, urge o acompanhamento de mães e lactentes dessas famílias, para garantir a valorização e oportunidade do AME e práticas que favoreçam a segurança alimentar de crianças e adultos que vivem em situações de extrema pobreza como as aqui retratadas.

Palavras-chave: Aleitamento materno. Pobreza. Saúde da Mulher. Interacionismo Simbólico. Discurso do Sujeito Coletivo. 


\begin{abstract}
PEREIRA, JF. The meaning of breastfeeding for the women living in a community in high social vulnerability in Alagoas state. 2014. 189f. THESIS (Doctorate) - School of Nursing, Federal University of São Paulo, São Paulo, 2014.
\end{abstract}

The social context of poverty demands effective practices to assure nutritional quality and safety for children, including breastfeeding. Nevertheless, breastfeeding rates in low-income populations are far from promising, pointing at a need to identify how breastfeeding is carried out in poor communities. The objectives of the present study were: to understand the meaning of breastfeeding and how it takes place among the women living in the Mangabeira Community, located near the municipal sanitary landfill of Arapiraca, Alagoas state, Brazil. The qualitative method was used, with Symbolic Interactionism and the Weighing Risks and Benefits Model as the theoretical frameworks; and the Corporate Sustainable Development strategy was used to organize the data. Quantitative data were collected for the biological and social characterization of the women and of the breastfeeding practice. Through a descriptive approach, this analysis improved the understanding of the breastfeeding experience of the 35 study subjects. The participants were women living in the referred community, who survive by collecting recyclable material, and who had breastfed at least one of their children. The results reveal that the women have a low education level, income of two minimum salaries or less, mean age of 36.2, and a fecundity rate of 4.2 children per woman. Only $58.3 \%$ of the women reported having exclusively breastfed their children, and the breastfeeding median was 22.3 months, i.e., higher than that of Brazilian Northeastern States. Based on the qualitative data, three explanatory themes emerged from the breastfeeding experience: Determined to breastfeed: from knowing to needing; The breastfeeding practice: family and collective care; Weaknesses in valuing breastfeeding. Breastfeeding is used as a resource against the newborn's hunger, as the women face difficulties to obtain food from any other sources. Breastfeeding is also noticed as a fragile practice from the standpoint of the women's choices, as it can be replaced when other alternatives are available, and is subject to the woman's physical and emotional conditions, regardless it being acknowledged as important in meeting the child's needs. Because the importance of breastfeeding is undervalued, it is seen as a common, predictable and habitual experience, which is incorporated in one's everyday life whenever possible or needed. The meaning of breastfeeding to these women is revealed as being a merely common experience, one that is neither good nor bad. Conclusions: In addition to the social measures to provide benefits for poor families, there is an urgent need to follow the mothers and breastfeeding women of these families, 
so as to assure the valorization and opportunity of exclusive breastfeeding and the practices that favor the nutritional safety of children and adults living in extreme poverty, as those described herein.

Keywords: Brest feeding. Poverty. Women's health. Symbolic interactionism. Collective Subject Discourse. 


\section{RESUMEN}

PEREIRA, JF. Significado del amamantar para mujeres residentes en una comunidad de alta vulnerabilidad social del interior de Alagoas. 2014. 189f. TESIS (Doctorado) - Escuela de Enfermería, Universidad Federal de São Paulo, São Paulo, 2014.

El contexto social de pobreza exige prácticas efectivas para garantizar la calidad y seguridad alimentaria de los niños; entre ellas, el amamantamiento. Sin embargo, los índices de lactancia materna entre poblaciones de bajos ingresos no se muestran promisorios, indicando la necesidad de conocerse el proceso de la práctica de la lactancia materna en comunidades que conviven con la pobreza. Este estudio tuvo como objetivos: Comprender el significado de amamantar y de cómo se desarrolla la práctica de amamantamiento en mujeres residentes en la Comunidad Mangabeira, cercana al relleno sanitario de la ciudad de Arapiraca-Alagoas. Se adoptó el método cualitativo, utilizándose como referencial teórico el Interaccionismo Simbólico, Modelo Pensando Riesgos y Beneficios; la estrategia del DSC para organización de datos. Se recolectaron datos cuantitativos para la caracterización biológica y social de la mujer y sobre la práctica del amamantamiento, ampliaron en forma descriptiva el entendimiento de la experiencia de amamantamiento de las 35 participantes del estudio, residentes en la comunidad, que sobreviven recolectando materiales reciclados y que habían tenido la experiencia de amamantar al menos a uno de sus hijos. Los resultados muestran que ellas poseen baja escolarización, ingresos inferiores a dos salarios mínimos, media etaria de 36,2 años, tasa de fecundidad de 4,2 hijos por mujer. Apenas el 58,3\% de las mujeres refirió haber alimentado exclusivamente por amamantamiento a sus hijos, y la mediana de LM es de 22,3 meses, mayor a la correspondiente a los Estados del Nordeste. En base a los datos cualitativos, emergieron 3 temas explicativos de la experiencia de amamantar: Determinada a amamantar: del saber a la necesidad; Práctica de amamantar: Cuidado familiar y colectivo; Debilidades en la valorización del amamantamiento. El amamantamiento es utilizado como recurso contra el hambre del recién nacido, dado que les resulta difícil adquirir alimentos de otras fuentes, aunque se muestra como una práctica débil desde el punto de vista de la elección de las mujeres, pudiendo substituírsela por otro alimento si resulta posible obtenerlo, sujeto a la condición y disponibilidad física y emocional de la mujer para amamantar, a pesar de reconocérselo como importante para satisfacer las necesidades del niño. No siendo valorizado por su importancia en sí, el amamantamiento es visto como una experiencia normal, previsible y habitual, a incorporarse en su rutina siempre que resulte posible o necesario. El significado del amamantamiento para estas mujeres se muestra como resultando una experiencia ni buena ni mala, apenas normal. Consideraciones finales: Más allá de medidas sociales de distribución de beneficios para las 
familias carecientes, urge el seguimiento de madres y lactantes de estas familias, para garantizar la valorización y oportunidad de la Lactancia Exclusiva y prácticas que favorezcan la seguridad alimentaria de niños y adultos en situación de pobreza extrema como las aquí retratadas.

Palabras llave: Lactancia Materna. Pobreza. Salud de la Mujer. Interaccionismo Simbólico. Discurso del Sujeto Colectivo. 
Tabela 1- Distribuição das mulheres moradoras da Comunidade

Mangabeira, segundo a idade, Arapiraca, 2014

Tabela 2- Distribuição das mulheres moradoras da Comunidade

Tabela 3- Distribuição das mulheres moradoras da Comunidade

Mangabeira, segundo renda familiar estimada, em saláriomínimo, Arapiraca, 2014

Tabela 4- Distribuição das mulheres moradoras da Comunidade

Mangabeira, segundo paridade, Arapiraca, 2014

Tabela 5- Distribuição das mulheres moradoras da Comunidade Mangabeira, segundo acesso ao pré-natal por gestação, Arapiraca, 2014

Tabela 6- Distribuição das mulheres moradoras da Comunidade Mangabeira, segundo quantidade de abortos, Arapiraca, 2014

Tabela 7- Distribuição das mulheres moradoras da Comunidade Mangabeira, segundo quantidade de filhos vivos em AME até seis meses e os que tiveram a $\mathrm{AMC}$ antes dos seis meses, Arapiraca, 2014 


\section{LISTA DE QUADROS}

Quadro 1 - Apresentação geral dos temas e as ideias centrais sínteses dos DSC.

Quadro 2 - Temas 1: Determinada a amamentar: do saber à necessidade.

Quadro 3 - Temas 2: Prática de amamentar: Cuidado familiar e coletivo.

Quadro 4 - Temas 3: Fragilidades na valorização da amamentação. 


\section{LISTA DE GRÁFICOS}

Gráfico 1 - Distribuição da média de partos, por faixa etária, das 100 mulheres moradoras da Comunidade Mangabeira, Arapiraca, 2014. 


\section{LISTA DE ABREVIATURAS}

$\begin{array}{ll}\text { UFAL } & \text { Universidade Federal de Alagoas } \\ \text { Et al } & \text { Colaboradores } \\ \text { OMS } & \text { Organização Mundial de Saúde } \\ \text { WHO } & \text { World Health Organization } \\ \text { AM } & \text { Aleitamento Materno } \\ \text { AME } & \text { Aleitamento Materno Exclusivo } \\ \text { AMP } & \text { Aleitamento Materno Predominante } \\ \text { AMC } & \text { Aleitamento Materno Complementado } \\ \text { DSC } & \text { Discurso do Sujeito Coletivo } \\ \text { TCLE } & \text { Termo de Consentimento Livre e Esclarecido } \\ \text { Unicef } & \text { Fundo das Nações Unidas para a Infância }\end{array}$




\section{SUMÁRIO}

1 INTRODUÇÃO

1.1 ALEITAMENTO MATERNO: UM BREVE RESGATE 21 HISTÓRICO, AO BRASIL DOS DIAS ATUAIS.

1.2 POBREZA E ALEITAMENTO MATERNO: QUE 28 RELAÇÃO É ESSA.

1.3 INTERFACE DE CATADORES DE LIXO COM 33 SAÚDE E ALEITAMENTO MATERNO

2. OBJETIVOS 42

3 PRINCÍPIOS TEÓRICO-METODOLÓGICOS DA 44 PESQUISA

3.1 INTERACIONISMO SIMBOLICO 46

3.2 MODELO TEÓRICO -"Pesando Riscos e Benefícios 54

3.3 PROCEDIMENTOS METODOLÓGICOS

3.3.1 Contexto da pesquisa $\quad 56$

3.3.2 Sujeitos da pesquisa $\quad 57$

3.3.3 Obtenção dos Dados para a Pesquisa

3.3.4 Análise de dados descritivos $\quad \mathbf{6 0}$

3.3.5 Análise de dados qualitativos $\quad 61$

3.3.6 Estratégia metodológica - Discurso do Sujeito Coletivo 62

3.3.7 Aspectos éticos da pesquisa $\quad 65$

4 ANÁLISE E DISCUSSÃO DOS DADOS

4.1 AS CARACTERÍSTICAS DAS MULHERES, DA 68 FAMILIA E DA COMUNIDADE

4.1.1 Descrição da renda familiar 73

4.1.2 Características das relações de trabalho 76

4.1.3 Percepção do local de moradia $\quad 84$

4.1.4 Enfrentando a fome $\quad 90$

4.2 EXPERIÊNCIAS MATERNA DA GESTAÇÃO, 98 PARTO E CUIDADOS COM FILHOS

4.2.1 Ciclo anticoncepção, concepção e aborto 98

4.2.2 Doença e morte de filhos pequenos 110

4.3 AMAMENTAÇÃO: UM RECURSO CONTRA A FOME, NEM BOM, NEM RUIM - NORMAL

4.3.1 Um retrato da prática de amamentação 115

4.3.2 TEMA 1 - Determinada a amamentar: do saber à necessidade 120

4.3.3 TEMA 2 - Prática de amamentar: Cuidado materno, familiar 133 e coletivo.

4.3.4 TEMA 3 - Fragilidades na valorização da amamentação 139

5 Á GUISA DAS CONSIDERAÇÕES FINAIS 156 REFERÊNCIAS $\quad 163$

APÊNDICES $\quad 184$

ANEXOS 188 


\section{INTRODUÇÃO}

\subsection{ALEITAMENTO MATERNO: UM BREVE RESGATE HISTÓRICO DO BRASIL DOS DIAS ATUAIS}

A conviç̧ão de que o aleitamento materno é o melhor alimento para a criança é defendida por várias organizações de saúde, em busca da redução da morbimortalidade infantil. Órgãos internacionais da saúde, como a Organização Mundial da Saúde (OMS) e o Fundo das Nações Unidas para a Infância (UNICEF) estabeleceram a nutrição infantil como uma de suas prioridades. Por isso, a proteção, a promoção e o apoio ao aleitamento materno têm sido estratégias mundialmente relevantes no setor de saúde e outros setores sociais para, entre outros esforços, melhorar as condições de saúde das crianças (OMS, 2003).

As práticas alimentares têm impacto significativo no estado nutricional, crescimento e desenvolvimento, saúde e sobrevivência das crianças cujos benefícios do aleitamento materno têm sido relacionados às menores taxas de diarreia, infecções do trato respiratório, otite média, entre outras infecções que resultam em menor mortalidade por essas doenças em crianças amamentadas quando comparadas com as não amamentadas (OMS, 2003).

A amamentação também tem sido associada a taxas mais baixas de doenças crônicas do adulto, incluindo obesidade e diabetes, alergias em geral, dermatite atópica e rinite alérgica. Além disso, há indicações de que crianças amamentadas ao peito apresentam melhores índices de acuidade visual, desenvolvimento neuromotor, desenvolvimento cognitivo e quociente intelectual (VICTORIA et al., 1987; POPKIN et al.,1990; OMS,1992; LEÓN-CAVA., 2002; SCHACK-NIELSEN; MICHAELSEN; 2006; IP et al., 2007).

A literatura especializada aponta como vantagens do aleitamento materno, para a saúde da mulher, a redução de estresse e mau humor, mediada pela ocitocina; a sensação de bem-estar, devido à liberação 
endógena de betaendorfina; a promoção da contração uterina pela ocitocina liberada com a sucção do bebê, com menor sangramento pós-parto e, conseqüentemente, menor incidência de anemias e retardo na volta da menstruação; em virtude do maior intervalo interpartal com consequências demográficas, maior rapidez na perda de peso pós-parto, além de indicar que, a longo prazo, a amamentação materna reduz o risco de diversos tipos de doenças, como câncer de mama, ovário e endometrio, artrite reumatoide e menos fraturas ósseas por osteoporose (OMS,1992; KRAMER; KAKUMA, 2004; ANTUNES et al., 2008; TOMA; REA, 2008; THAPA et al., 1988; LABBOK, 2008).

Os benefícios do aleitamento materno não é só para a mãe e para a criança, como descrito acima, mas também para a família, para as instituições e para a sociedade. Assim é possível observar algumas vantagens, como economia com alimentação do recém-nascido e medicamentos; redução dos gastos institucionais com aquisição de fórmulas, frascos, bicos artificiais e medicamentos; redução da poluição ambiental com menos lixo inorgânico, resultante do consumo de bicos artificiais e de mamadeiras (TOMA; REA, 2008).

Os últimos estudos indicam que a melhoria da nutrição nos primeiros anos de vida, com a amamentação, leva a melhorias na saúde das crianças e assim potenciliza o desempenho econômico dos individuos na idade adulta (BAKER, 1994; GLUCKMAN; HANSON; 2006; PALLONI, 2006; STUEBE, 2009). Estudos também descobriram que crianças amamentadas exclusivamente ou que foram amamentadas por mais tempo, têm melhor pontuação escolar na infância (DANIELS; ADAIR; 2005; QUINN et al., 2001; MICHAELSEN et al., 2003; SACKER et al., 2006 ; KRAMER et al., 2008) e na idade adulta (RICHARDS et al., 2002), em testes de desenvolvimento cognitivo e motor.

Nos países menos desenvolvidos, as crianças muitas vezes não conseguem atingir o desenvolvimento cognitivo ideal por causa da pobreza, desnutrição e problemas de saúde (GRANTHAM-MCGREGOR et al., 2007; BEHRMAN, 1996). Nesse cenário, alguns autores apontam que as mulheres de menor escolaridade e nível socioeconômico mais baixo podem 
não ter acesso a comprar e manter uma alimentação adequada, porém pode ter mais tempo disponível para amamentar em comparação com as mulheres de maior renda. Assim, a amamentação pode ser mais prontamente disponível como uma estratégia para melhorar a saúde de seus filhos, e também poderia ser mais comum entre as mães mais pobres, cujos filhos estão em maior risco (NEGI; KANDPAL; 2004; SKAFIDA, 2009).

Se, por um lado, o conhecimento sobre os benefícios da amamentação para a saúde das crianças, mães e para sociedade aparece de forma consistente, por outro lado, a duração dessa prática é curta em muitas partes do mundo, incluindo o Brasil, apesar de as mães relatarem frequentemente a sua vontade de amamentar como recomendado pelos serviços de saúde (BRASIL, 2009; CAMINHA et al., 2010).

Baseado no modelo evolutivo é possivel compreender que, no cenário das escolhas, a primeira é a garantia da sobrevivência (HAIG, 2008; VITZTHUM, 2008). Esse padrão cognitivo e comportamental é definido ao longo da história evolutiva dos homens. Portanto, vários antropólogos, ao analizarem a relação da alimentação infantil, identicaram que os planos de amamentação não são estáticos, por isso as mães têm a opção de amamentar ou podem usar alternativas disponíveis para a alimentação infantil. Até mesmo durante o processo de amamentação o equilibrio pode ser alterado por fatores exógenos ou endógenos (SCHEPR-HUGHES, 1992; MCDADE; WORRTMAN; 1998, SELLEN, 2007).

Os relatos históricos confirmam que, para as mulheres aristocratas e burguesas do século XVII e XVIII, o ato de amamentar era considerado repugnante e com isso tinham como prática a adoção de ama de leite. Esse comportamento era tomado como exemplo pelas mulheres de classes menos favorecidas e essa prática europeia foi trazida pelos colonos ao Brasil. $\mathrm{Na}$ Europa, no final do século XVIII e início do século passado, as crianças recebiam o leite de animais em chifres. Na metade do século XIX passou a ser adotado como tratamento em clínicas pediátricas já na primeira metade do século XX (CAVALCANTE, 1982; TUDISCO et al.,1984; BADINTER, 1985). 
A ampliação tecnológica e todas as mudanças relacionadas à Revolução Industrial, como o trabalho feminino e o desenvolvimento da fórmula láctea por meio da pasteurização do leite, favoreceram a diminuição da amamentação. Como consequência desse processo de desmame precoce, as taxas de mortalidade infantil tiveram um elevado crescimento, com maior impacto, nas populações pobres dos países não desenvolvidos (MONTEIRO et al., 1998). Com o intuito de reverter essa situação, vários estudos e estratégias foram adotados pelos governos e vêm sendo utilizados para reverter esse processo de predomínio da alimentação de lactentes por leite industrializado em detrimento do leite materno.

O Brasil vem seguindo, mesmo por vezes de forma tardia, os alertas e as recomendações adotadas pelas diversas organizações internacionais para a necessidade de estímulo às práticas de aleitamento materno. O Programa de Incentivo ao Aleitamento Materno foi instituído em 1981 e desde então vem propondo uma diversidade de ações, que incluem campanhas na mídia, treinamento de profissionais, entre outras.

Atualmente, a Política Nacional de Incentivo ao Aleitamento Materno está organizada em seis áreas estratégicas. Sendo elas: O monitoramento das práticas de aleitamento materno no País é realizado pelos inquéritos Nacionais e por meio da Pesquisa Nacional de Demografia e Saúde. As ações da atenção básica são realizadas desde 2008 por intermédio da rede Amamenta. A atenção hospitalar conta com duas iniciativas, o Hospital Amigo da Criança e o método canguru que vem sendo implantado desde 2000 nas maternidades. A Rede Brasileira de Bancos de Leite Humano é outra estratégia que vem sendo fomentada desde 1998 e conta com o apoio dos Correios com o Projeto Carteiro Amigo, com o Corpo de Bombeiros os quais buscam leite humano doado nas residências, em alguns estados brasileiros. $\mathrm{O}$ aparato legal conta com a Norma Brasileira de Comercialização de Alimentos para Lactentes de 1988, com a licença maternidade ampliada, em 2008, para seis meses, e a Portaria N. ${ }^{\circ} 193$, de 23 de fevereiro de 2010, que orienta a instalação de salas de apoio à amamentação em empresas públicas ou privadas e a fiscalização desses ambientes pelas vigilâncias sanitárias locais (BRASIL, 2009). 
Passados praticamente 30 anos, após o inicio de todo movimento pró-aleitamento no Brasil, pode-se perceber que, embora alguns trabalhos demonstrem uma melhora significativa da situação de aleitamento materno, distantes o ideal proposto pela OMS, de aleitamento materno exclusivo até o sexto mês de vida e manutenção da amamentação até o segundo ano de vida ou mais, ainda não foi atingida na sua totalidade (BRASIL, 2009).

Nos países em desenvolvimento, estudos indicavam que menos de $40 \%$ das crianças são aleitadas somente ao seio durante os primeiros seis meses de vida, o que ainda era considerado muito baixo (OMS, 2003). No Brasil, estudos da primeira década de avaliação do programa de incentivo ao aleitamento materno apontam um aumento da duração mediana da amamentação (VENÂNCIO; MONTEIRO; 1998; BENFAM, 1997). Apesar da tendência de melhoria da prática do aleitamento materno, a amamentação permanece exclusiva em apenas $41 \%$ das crianças menores de seis meses (BRASIL, 2009). Paralelamente, investigações mostram que a alimentação complementar vem sendo frequentemente introduzida de forma precoce, muitas vezes com alimentos impróprios ou inseguros para a saúde, o que contribui para desnutrição, obesidade e outras morbidades infantis (OMS, 2003; MONTE; GIULIANI, 2004; OMS, 2010). Água, chás, sucos e outros leites são os alimentos mais consumidos de acordo com os resultados de pesquisas nacionais (SIMON et al., 2003; BRUNKEN et al., 2006).

A Pesquisa Nacional de Demografia e Saúde (PNDS - 2006), por exemplo, apontou que $15,3 \%$ das crianças de quatro a seis meses de vida estavam em aleitamento materno exclusivo (AME), enquanto 62,4\%, além do leite de peito, recebiam outros alimentos - outros leites (41,7\%), mingau (31,6\%) e comida de sal (22\%) (BRASIL, 2008). Já em 2008, estudo mostrou que $20,7 \%$ e $24,4 \%$ das crianças de três a seis meses consumiam comida salgada e fruta, respectivamente (BRASIL, 2009). Mais especificamente no estado de São Paulo, Venâncio et al. (2010) observaram que $58 \%$ das crianças de quatro meses já haviam recebido água; $51 \%$, outro leite; $25 \%$, suco de frutas; $24 \%$, mingau e $20 \%$, fruta amassada.

A adesão ao processo de amamentação exclusiva pode ser influenciada tanto positiva como negativamente, por vários fatores 
relacionados à nutriz, à criança e ao ambiente, entre eles: características da personalidade materna diante à amamentação, condições de nascimento e período pós-parto, trabalho materno, condições habituais de vida, incluindo crenças e tabus e até mesmo o despreparo das equipes de saúde (FALEIROS et al., 2006).

Já na década de 1980, autores criticavam as campanhas de incentivo ao aleitamento materno que preconizavam a amamentação como forma natural da mãe alimentar seu filho. Eles se referiam à necessidade de revisão dessa estratégia, pois sua intervenção ocorre de forma superficial não sendo de fato efetiva para mudança da realidade, já que essa modificação envolve vários outros fatores bem mais profundos como os comportamentais (FADUL et al., 1983; SEPÚLVEDA, 1983).

É no início da década de1990 que se iniciaram os questionamentos sobre as outras peculiaridades do processo de amamentar, buscando compreender a vivência da mulher nesse processo. Assim, percebe-se a mulher como agente da amamentação em que as questões sociais e culturais passam a ser consideradas como elementos na construção do comportamento dos indivíduos e de saberes sobre o processo de amamentar (SILVA, 1990; SILVA, 1997; ARAÚJO, 1991).

Um dos aspectos importantes que passam a ser considerados, a partir de então, é o fato de a amamentação estar atrelada aos fatores sociais e culturais, tanto quanto a lactação é resultado de um equilíbrio biológico e hormonal da mulher. As referências sobre amamentação são construídas pela própria sociedade e são produtos da construção econômica e social com que esta sociedade se insere e se edifica (SILVA, 1994).

Assim, centrando a amamentação numa rede de promoção, proteção, apoio, é possível que se estabeleça um novo foco sobre a mulher, que não pode continuar a ser tratada como sinônimo de mãe-nutriz, responsável pelo êxito da amamentação e culpada pelo desmame (ALMEIDA; NOVAK, 2004). Entretanto, como sujeito que vê a amamentação biologicamente determinada e percebendo seu limite por meio do desenvolvimento de seu aprendizado na prática, pode “[...] se deparar com sentimentos ambíguos e 
contraditórios, oscilando entre interpretações sobre o exercício de amamentar como um desejo ou obrigação" (SILVA,1997).

Seguindo esse contorno, Almeida e Novak (2004, p.125) ressaltam que:

$\mathrm{Na}$ direção de um posicionamento que recusa a redução, tanto na dimensão biológica quanto na social, a categoriza da amamentação como um híbrido natureza-cultura procura perseguir a abordagem da amamentação como reflexo de determinantes biológicos e condicionantes sociais, econômicos, políticos e culturais. Num movimento, contrário à dicotomia costumeira estabelecida entre o biológico e o social, gerando novas oportunidades teórico-metodológicas na forma de operar com as questões que permeiam a amamentação, possibilitando uma revalorização da biologia e um aprofundamento nos processos interdisciplinares que permeiam a temática.

E assim, ao considerar o ambiente e o contexto social, os marcos do momento da vida da mulher e sua visão sobre o processo de amamentar, é possível compreender o seu entorno e buscar os elementos que constituem forças formadoras da experiência e da pratica de amamentação (ALMEIDA,1999). 


\subsection{POBREZA E ALEITAMENTO MATERNO: QUE RELAÇÃO É ESSA}

Pobreza é um conceito multidimensional, atualmente não se pode estabelecer uma linha de pobreza e aplicá-la a todos da mesma forma, sem tomar em conta as características e circunstâncias pessoais. Sabe-se que a análise da pobreza também deve concentrar-se na capacidade da pessoa para aproveitar oportunidades presentes em seu contexto de vida, assim como a busca nos cuidados com saúde, nutrição e em seu desenvolvimento educacional, tudo isso refletindo diretamente na sua capacidade básica como cidadão. Essas constatações são determinantes para se perceber, de fato, o real potencial de ação da promoção da saúde entre os pobres e as estratégias de empoderamento individual e coletivo (WORLD BANK, 2000; ECLAC, 2006; BUSS, 2007).

Apesar de a riqueza mundial estar estimada atualmente em 24 trilhões de dólares anuais e em contínuo aumento, cerca de 1,2 bilhões de pessoas em todo o mundo vivem com menos de um dólar por dia, em uma situação classificada como de "extrema pobreza", enquanto nada menos que metade dos habitantes do mundo vivem com menos de dois dólares por dia. $\mathrm{Na}$ África Subsaariana, quase a metade dos habitantes vivem com menos de um dólar por dia, enquanto na Ásia Meridional cerca de 37\% da população (448 milhões) têm as mesmas condições de pobreza. Na América Latina e Caribe, 222 milhões são pobres, dos quais, 96 milhões vivem na indigência, ou 18,6\% da população. (WORLD BANK, 2000; ECLAC, 2006; BUSS, 2007).

O Brasil, nas últimas décadas, passou por intensa melhora dos indicadores de saúde e nutrição (MINAYO et al., 2000), com evolução especial no grupo materno-infantil. No entanto, todo esse desenvolvimento não ocorreu de forma homogênea dentro e entre as grandes regiões geográficas do País. Junto a esse cenário da desigualdade entre as regiões do País, há o acesso diferenciado ao saneamento básico, aos serviços de saúde, ao teto salarial e à educação (IBGE, 2004). Esse quadro caracteriza a situação de desigualdade inter-regional com o Norte e o Nordeste do País 
concentrando os maiores índices de desigualdade social podendo pressupor que a sua reprodução ocorra também dentro das próprias regiões citadas, caracterizando disparidades no acesso a serviços e ao consumo alimentar que se pode expressar em desigualdades na saúde (ASSIS, 2007).

Partindo do pressuposto de que a desigualdade, a pobreza e a enfermidade constituem um típico movimento de retroalimentação (WAGSTAFF，2002; SIQUEIRA-BATISTA; SCHRAMM; 2005) e que esse conjunto de vulnerabilidades sociais e ambientais está na base da geração de iniquidades em saúde (SOBRAL; FREITAS; 2010), os programas de proteção social, e mais especificamente de transferência de renda, têm ganhado importância, pois manifestam o papel protetor que deve ser desempenhado pelo Estado nas sociedades democráticas de direito (PONTES; SCHRAMM; 2004; SCHRAMM, 2008).

Nesse domínio, o Programa Bolsa Família (PBF) merece especial destaque, por representar, atualmente, a principal política do Governo Federal brasileiro para redução da pobreza, que associa a transferência de renda às famílias consideradas pobres e extremamente pobres a contrapartidas na utilização dos serviços nas áreas de saúde e educação, além do oferecimento de ações e programas complementares (de geração de emprego e renda, a cargo de cada município). Objetiva, assim, além de enfrentar a pobreza, estimular o desenvolvimento de capital humano e emancipação sustentada da população alvo (BRASIL, 2004; MAGALHÃES et al., 2007).

Mesmo que algumas melhorias sejam percebidas na diminuição da pobreza extrema, os mais pobres continuam vivendo em piores condições sociais, ambientais e sanitárias; consequentemente a dificuldade no acesso aos serviços públicos em geral e de saúde em particular permanecem. Isso é apontado em inúmeros estudos, em diversas partes do mundo, os que têm pior renda são exatamente aqueles que, certamente mais necessitados, têm também pior acesso a políticas públicas, habitações adequadas, água potável, saneamento, alimentos, educação, transporte, lazer, emprego fixo e sem riscos, assim como aos serviços de saúde. São as chamadas iniquidades sociais e de saúde (WORLD BANK, 2000; ECLAC, 2006; BUSS, 2007). 
As repercussões de todo esse processo podem ser observadas em diversos eventos, como a mortalidade infantil, o prejuízo do desenvolvimento físico e mental das crianças, o baixo peso ao nascer, a mortalidade materna, o aumento da evasão escolar e a diminuição do desempenho acadêmico são eventos relacionados à carência de alimentação saudável e de qualidade, como consequência do acesso precário à renda, a bens e serviços (CAMPBELL, 1991).

O ambiente social e econômico, em que vive a criança e sua família, tem sido reconhecido como importante preditor das condições de saúde e nutrição na infância (ASSIS, 2007). O incentivo ao aleitamento materno está entre as ações promotoras de segurança alimentar, à medida que as recomendações nacionais e internacionais preconizam o estímulo a essa prática, sem complementação com nenhum outro alimento até o sexto mês de vida (PÉREZ-ESCAMILHA,1993; COULILALY et al., 2006).

As vantagens da amamentação para a saúde da criança têm sido reiteradas em diferentes realidades socioculturais, pois sua prática contribui para a redução da incidência e gravidade de uma série de morbidades (FUJIMORI et al., 2010). Tais vantagens vão além da proteção biológica fornecida pelo leite materno, e chegar a uma dimensão econômica, gerando impactos positivos sobre os serviços de saúde, familiares e sociedade (ALMEIDA; NOVAK; 2004; CAMINHA et al., 2010).

Apesar dos estudos serem unânimes em atestar que o leite materno é o melhor alimento para o lactente, a prevalência e duração do aleitamento materno variam de acordo com a época e os diferentes contextos socioculturais (PÉREZ-ESCAMILHA, 1993). Em países desenvolvidos, há estudos que continuam a evidenciar que mulheres pobres amamentam menos e por períodos mais curtos (COULIBALY et al., 2006). No entanto, outros estudos, como o realizado em nove países da America Latina, encontrou que mães com baixa escolaridade amamentam por mais tempo os seus filhos do que mães com educação mais avançada (PÉREZESCAMILHA, 1993). Realidade também encontrada em estudos no México e nas Filipinas, onde as mulheres mais pobres amamentam por mais tempo (LONG- DUNLAP et al., 1995 , CONAPO, 2000; GONZALEZ-COSSIO et 
al., 2007; CUPIL-UICAB et al., 2009), e evidenciando que a tendência é que as mulheres com maior escolaridade amamentem seus filhos por menos tempo ( NEGI; KANDPAL; 2004; SKAFIDA, 2009, CUPIL-UICAB et al., 2009), provavelmente por reflexos de limitações impostas sobres elas, mulheres trabalhadoras, durante o período de amamentação, pois com certeza são mais propensos a reconhecer os benefícios da amamentação, mas devido a sua presença no mercado de trabalho, isso pode limitar as oportunidades para a amamentação.

No Brasil, os dados disponíveis são bastante divergentes, sendo relevante considerar o uso de diversas metodologias assim como diferentes contextos socioculturais e históricos que limitam a capacidade de comparação dos resultados das pesquisas. Há evidências de que o baixo nível socioeconômico não se associa com a interrupção precoce do aleitamento materno (GIUGLIANI et al., 1996; FUJIMORI et al., 2010; DAMIÃO, 2008). Assim como estudo pernambucano de Vasconcelos, et al. (2006), que encontrou duração mediana do aleitamento materno maior em mães com renda mais elevada. Complementar a essa informação outro evidencia que mães jovens, com pouca escolaridade, e de baixa renda, foram identificadas como as de risco aumentado para o desmame precoce (WARKENTIN, et al., 2013)

No entanto, outros estudos indicam a existência de associação entre precárias condições de vida e maiores frequência e duração do Aleitamento Materno (PEDROSO et al., 2004; OLIVEIRA et al., 2005), como no estudo de coorte da cidade de Pelotas - RG, (HORTA et al., 2007) que em ambos os grupos acompanhados, houve interação entre a renda familiar e os percentuais de crianças amamentadas em diferentes idades. Nos primeiros meses, tais percentuais foram superiores nas famílias de maior renda, mas, a partir de nove meses, a amamentação foi mais frequente no grupo de baixa renda. A Pesquisa Nacional de Demografia e Saúde, realizada no Brasil em 2006, detectou medianas de duração do aleitamento materno mais altas que a mediana nacional no Norte e Nordeste do Brasil, entre os filhos de mulheres de baixa escolaridade. Nesse grupo, a introdução precoce de leite 
não materno foi alta, mesmo entre as crianças amamentadas, tendo como alimento complementar mais frequente o mingau (BRASIL, 2008).

Em suma, fica claro que dentre as inúmeras condições que podem intervir nos processos de amamentação, as condições sociais e dificuldades econômicas ganham destaque por favorecer várias situações de dificuldades concretas e objetivas de vida de mulheres e famílias que, muitas vezes, podem ser apontadas como provocadoras do desmame precoce. Entre elas, a necessidade de exercer atividade extralar para ajudar na subsistência da família, pressão emocional pelo desgaste físico e emocional de mulheres em situações de pobreza, são algumas delas (SILVA, 2005).

Ainda é importante citar que em 2004, o gasto médio mensal com a compra de leite para alimentar um bebê, nos primeiros seis meses de vida no Brasil, variou de $38 \%$ a $133 \%$ do salário-mínimo, dependendo da marca da fórmula infantil. A esse gasto devem-se acrescentar custos com mamadeiras, bicos e gás de cozinha, além de eventuais gastos decorrentes de doenças, que são mais comuns em crianças não amamentadas. Constituindo maiores dificuldades e sacrifícios para uma família de pouca renda (BRASIL, 2009).

Assim, os conflitos encontrados nos diferentes estudos quantitativos que abordam a amamentação e as condições socioeconômicas, podem ter seu horizonte ampliado com a utilização de outras abordagens metodológicas. Com o intuito de elucidar fatos que possam melhorar as ações desenvolvidas para orientação e incentivo às mães no processo de amamentação de seus filhos (VASCONCELOS et al., 2006).

Nesse sentido, a distribuição justa da riqueza socialmente produzida é um pressuposto básico da inclusão social e econômica e da equidade em saúde e nutrição. No entanto também que as políticas de saúde podem diminuir as desigualdades (ASSIS, 2007).

Da mesma forma, o conhecimento sobre as tendências locais do padrão de amamentação é fundamental, pois permite avaliar os serviços de saúde e embasar mudanças e ajustes necessários às práticas de promoção e incentivo ao aleitamento materno com intuito de melhoria das condições de saúde e alimentação de crianças pequenas (PEDROSO et al., 2004). 


\subsection{INTERFACE DE CATADORES DE LIXO COM SAÚDE E ALEITAMENTO MATERNO}

Várias são as consequências trazidas pela transformação dos processos produtivos nas regiões ligadas basicamente à produção primária agrícola, como é o caso de cidades em franco desenvolvimento econômico no interior de estados brasileiros. Se, por um lado, essas transformações proporcionam avanços, principalmente tecnológicos, por outro, ocasionam a exclusão social. Paralelo a tanta tecnologia, concentrada em apenas alguns grupos, percebe-se que muitas pessoas não têm acesso à educação nem aos avanços tecnológicos. Vivem sem o mínimo de condições econômicas, e, consequentemente, acabam excluídas, principalmente do mercado de trabalho.

Esse tipo de fenômeno pode ser visto, a exemplo, na cidade de Arapiraca, Alagoas, o que ocasionou, por sua vez, o chamado mercado informal, onde trabalham as pessoas que não se encaixam no padrão referencial das inúmeras habilidades exigidas na atualidade, como, por exemplo, os catadores de lixo reciclável (OZONOFF et al., 1987; WILHEM, 1989).

Além disso, atualmente, o homem costuma ser valorizado pela capacidade de consumo. O sujeito em busca da integração com o espaço social tem se deparado com um mundo onde, desamparado e desabrigado, procura acolhimento para o seu sentimento de despedaçamento. Na ausência ou na impossibilidade desse acolhimento, o homem costuma considerar intocáveis os ideais estabelecidos pela moral social. Diante da impotência gerada por uma ideologia não condizente com a sua realidade, o sujeito pode tornar-se alienado, e incapaz de questionar os valores vigentes e, menos ainda, de reagir, instituindo, dessa forma, uma sociabilidade marginal e muitas vezes perversa (VELLOSO, 2005).

É importante resgatar que no Brasil, como em grande maioria dos países, a forma de disposição de resíduos, mais difundida e que se preserva até os dias de hoje é sobre o solo, em "lixões". Assim, o crescimento da população urbana contribuiu significantemente para um aumento na geração 
de resíduos, o que não veio acompanhado da preocupação com a necessidade de se ter locais específicos para a sua disposição (GOUZIE et al., 1998). Algumas alternativas técnicas vêm sendo estudadas e aplicadas no mundo, dentre as quais merecem destaque a reciclagem, a compostagem e o aterramento sanitário. Apesar dessas alternativas, muitos municípios do Brasil continuam a dispor seus resíduos de forma inadequada, em locais inicialmente afastados dos núcleos populacionais, causando problemas ambientais, por gerar contaminação dos solos, do ar e das águas, superficiais e subterrâneas, alterando suas características físicas, químicas e biológicas, e colocando em risco a saúde humana (GOLDBERG et al., 1999; PEREIRA NETO, 2007). Com o crescimento na maioria das vezes desordenado das cidades, esses lixões antes afastados se integraram nas áreas urbanas.

As discussões sobre a problemática que envolve essa temática não são novas. O tema tem se mostrado prioritário desde a Conferência Rio 92, em escala global, tanto nos países ricos quanto nos mais pobres, por contribuir direta ou indiretamente com o aquecimento global e as mudanças do clima. Desde a Rio 92, incorporaram-se novas prioridades à gestão sustentável de resíduos sólidos que representaram uma mudança paradigmática, que tem direcionado a atuação dos governos, da sociedade e da indústria. Incluem-se nessas prioridades a redução de resíduos nas fontes geradoras e a redução da disposição final no solo, a maximização do reaproveitamento da coleta seletiva e da reciclagem com inclusão socioprodutiva de catadores e participação da sociedade, a compostagem e a recuperação de energia (McGRA- NAHAN; SATTERTHWAITE; 2002; IPCC, 2007).

Os municípios são responsáveis pela gestão dos resíduos, mas só recentemente teve sua política definida na Lei n. $^{\circ} 11.445$, de 2007 , na qual o plano de resíduos sólidos deve integrar os planos municipais de Saneamento e na Política Nacional de Resíduos Sólidos (PNRS), Lei n. ${ }^{\circ}$ 12.305, de 2010, regulamentada por meio do Decreto n. 7.404, de 2010, que após vinte anos de tramitação no Congresso Nacional estabeleceu um novo marco regulatório para o Brasil. Inova no País, ao propor a responsabilidade compartilhada pelo ciclo de vida dos produtos e a logística reversa de 
retorno de produtos, a prevenção, precaução, redução, reutilização e reciclagem, metas de redução de disposição final de resíduos em aterros sanitários e a disposição final ambientalmente adequada dos rejeitos em aterros sanitários. No aspecto de sustentabilidade socioambiental urbana cria mecanismos de inserção de organizações de catadores nos sistemas municipais de coleta seletiva e possibilita o fortalecimento das redes de organizações de catadores e a criação de centrais de estocagem e comercialização regional (ABRELPE, 2009).

Nos últimos anos tem-se verificado uma melhoria em alguns indicadores no cenário brasileiro dos resíduos sólidos no Brasil, entre eles o atendimento da população pelos serviços de coleta de resíduos domiciliares na zona urbana está próximo da universalização com uma expansão de 79\%, no ano 2000, para 97,8\%, em 2008 (IBGE, 2010). A coleta dos resíduos sólidos urbanos está cada vez mais privatizada, e o número de empresas filiadas à Associação Brasileira de Empresas de Limpeza Pública e Resíduos Especiais (Abrelpe) passou de 45, em 2000, para 92, em 2009, tais empresas coletaram cerca de 183 mil toneladas de lixo diariamente em 2009. A média de geração de resíduos sólidos urbanos no País, segundo projeções da Abrelpe (2009), varia de um a 1,15 kg por hab./dia, padrão próximo aos dos países da União Europeia, cuja média é de $1,2 \mathrm{~kg}$ por dia por habitante. O Brasil é hoje uma referência mundial em termos de reciclagem. Atualmente, o País é recordista na transformação de latas de alumínio e apresenta índices elevados de reciclagem de vários tipos de embalagem, principalmente considerando o fato desse processo não ser obrigatório por lei, como acontece em outros grandes países recicladores (IBGE, 2010).

Para a Abrelpe (2009), enquanto o crescimento populacional foi de apenas 1\% entre os anos de 2008 a 2009, a geração per capita apresentou um aumento real de $6,6 \%$ na quantidade de resíduos domiciliares gerados, o que demonstra a ausência de ações com o objetivo de minimizar a geração de resíduos. O país gerou mais de 57 milhões de toneladas de resíduos sólidos em 2009, crescimento de 7,7\% em relação ao volume do ano 
anterior. As capitais e as cidades com mais de 500 mil habitantes foram responsáveis por quase 23 milhões de toneladas de resíduos sólidos/dia.

No entanto, cerca de metade dos 5.564 municípios brasileiros ainda dispõem em lixões, e o percentual de cidades que dispõem em aterros controlados permaneceu praticamente estagnado nos oito anos, 22,3\% (2000) e 22,5\% (2008). A crescente redução da disposição em lixões, verificada entre os anos 2000 e 2008, deve-se ao fato de as 13 maiores cidades, com população acima de um milhão de habitantes, coletarem mais de $35 \%$ de todo o lixo urbano do País e terem seus locais de disposição final adequados. Por sua vez, os aterros das grandes cidades caminham para a saturação, e os resíduos são transportados a longas distâncias (ABRELPE, 2009).

Nesse sentido, alguns estudos têm demonstrado que a disposição de resíduos de forma inadequada, como os lixões, além das questões ambientais tem afetado a saúde humana, aumentando assim a morbidade em crianças por diarreias, parasitoses entre outros problemas. Os resíduos sólidos urbanos devem ser compreendidos como um problema de saúde pública e as consequências de seu manejo e disposição final inadequados acabam se refletindo direta e indiretamente na saúde da população (HELLER; CATAPTRETA; 2003).

Infelizmente, as iniciativas brasileiras de coleta seletiva ainda são poucas, o mais comum é a criação de uma situação em que pessoas pobres convivem da pior maneira possível com resíduos que podem até fornecer um precário sustento, mas que certamente trarão doenças, agravarão as condições de vida da população e contribuirão para contaminar o ambiente. Como o lixo é considerado um achado valioso pela população carente, os catadores constituem-se em uma comunidade de risco, não apenas para sua própria integridade física e de saúde, como também são submetidos a uma condição de marginalidade social e econômica, que muitas vezes se confunde com o próprio conceito de lixo (DALL' AGNOL; FERNANDES; 2007; REGO et al., 2002).

Os estudos realizados apontam para um perfil de catadores, subdivididos em três categorias: catadores de rua, catadores cooperados e 
catadores de lixão. Denomina-se catador de rua a categoria que coleta em sacos de lixo colocados pela população na rua, pelo comércio local ou pelas indústrias, tendo sua própria carroça ou qualquer outro transporte adaptado para carga. Os catadores cooperativados e autogestionários são aqueles que prestam serviço de coleta seletiva de qualidade, de forma articulada e organizada, gerando trabalho e renda. Esses se organizam nacionalmente no Movimento Nacional dos Catadores, têm apoio de diversas organizações não governamentais e estão articulados em fóruns, buscando consolidar a sua participação nos programas municipais de coleta seletiva. Os catadores de lixão encaixam-se na relação direta de exclusão social, são aqueles que fazem a catação diretamente nos lixões dos municípios e que estão desvinculados de qualquer assistência e organização. Em face ao alto índice de desemprego, a estratégia de sobrevivência encontrada pela população de excluídos é "coletar lixo" como forma de obter a renda para o próprio sustento. Ao catar e separar os materiais recicláveis, seja em lixões, em ditos "aterros sanitários" ou ainda em usinas de reciclagem por todo País, o catador constitui atualmente um importante elo do sistema de reciclagem (PORTO et al., 2004; DALL' AGNOL; FERNANDES; 2007; REGO et al., 2002)

É em torno do ambiente inóspito do lixão que inúmeras famílias, por não terem uma alternativa melhor para manter a sua sobrevivência, acabam procurando no lixo a sua renda, por meio da catação e venda de produtos recicláveis. Desse modo esta atividade está diretamente ligada à sobrevivência imediata do seu grupo familiar, porém tal condição traz consigo a exclusão social que acaba implicando em outras situações, como estigmatização, 'falta' de cidadania, marginalidade (JUNCÁ et al., 2000).

Sendo assim, a condição de catador está muito associada, no imaginário popular, à condição da pobreza, que, por sua vez, para muita gente ainda é sinônimo de marginalidade, indolência, malandragem. Esses estigmas marcam profundamente a vida de uma pessoa, tornando-a desacreditada, principalmente, perante a sociedade (JUNCÁ et al., 2000).

Portanto, como tantas outras parcelas da população brasileira, eles têm sido estigmatizados por sua pobreza e tornam-se indiscriminadamente 
reconhecidos como classe perigosa, que acaba por gerar um processo de segregação espacial, com a constituição de verdadeiros guetos. E na vasta massa de trabalhadores que contribuem, de forma involuntária, para "o aumento dos índices de marginalidade, da criminalidade, da insegurança, da fome, da pobreza e da miséria nos bairros pobres" (JUNCÁ et al., 2000, p.96; OLINGER,1991).

Quando se trata das questões vinculadas à participação feminina no trabalho de catadores percebe-se uma maior vulnerabilidade social, principalmente, nos grupos familiares nos quais a mulher é a principal ou única provedora, não havendo um adulto do sexo masculino que compartilhe a responsabilidade pela subsistência da família. Essa vulnerabilidade estende-se principalmente para as crianças, interferindo diretamente em sua segurança alimentar (CASTRO, 2001).

De modo geral, os hábitos alimentares de crianças em regiões pobres, são pouco conhecidos, apesar da importância de compreender as reais carências e necessidades existentes nessas populações (SILVEIRA; LAMOUNIER; 2004).

Com a finalidade de identificar quantitativamente a prática de aleitamento materno e os fatores que influenciam na amamentação e sua associação com algumas variáveis indicativas de desigualdades sociais, foi realizado um estudo, em uma comunidade de extrema vulnerabilidade social, ambiental e física, que vive próxima ao lixão, localizada no interior de Alagoas - Comunidade da Mangabeira, Arapiraca, onde foram estudadas 140 crianças de seis meses a cinco anos, moradoras dessa localidade, sendo 66 meninos $(47,10 \%)$ e 74 meninas $(52,90 \%)$. Dessas verificou-se que $37,40 \%$ ainda mamavam e 58,30\% já tinham sido desmamadas, com a idade do desmame mostrando que $69,70 \%$ foram desmamadas depois dos seis meses. A introdução de água, de chá e de outros leite não maternos, 54,80\%, $60,15 \%, 40,75$, respectivamente, ocorreram antes dos seis meses, encontrando associação estatisticamente significante entre a introdução de água, chá e leite e a idade do desmame e medias de dias amamentados, ou seja, a introdução desses alimentos antes dos seis meses tem impacto 
negativo, favorecendo o desmame para esse grupo (ABADE; PEREIRA; 2009).

Alguns estudos no Brasil e no mundo demonstram altas prevalências de crianças que recebem leite materno, porém, o aleitamento materno exclusivo é quase sempre raro, incluindo a esses dados as altas prevalências de aleitamento materno encontrada na África 95\% e nas Américas de 65\%, (WHO, 1993), esse último dado, bem próximo aos encontrados no estudo de Abade e Pereira (2009).

Com base nos resultados encontrados no estudo na Mangabeira de Abade e Pereira (2009), comunidade moradora de um lixão, é possível levantar várias questões, que não foram apresentadas no estudo por sua limitação metodológica. Os estudos de prevalência de aleitamento materno em crianças valorizam pouco o contexto da nutriz, pois têm seu foco na análise quantitativa, associados tradicionalmente a variáveis socioeconômicas e de saúde e não nos aspectos subjetivos da experiência de amamentar da mulher assim como todos os elementos constituintes de seu cotidiano e de seu filho.

Nesse sentido, alguns estudos qualitativos afirmam que a amamentação está atrelada aos determinantes sociais e às manifestações da cultura, tendo a mulher como agente, em que suas referências são construídas e produzidas no seu meio socioeconômico, levando-se em conta a sua inserção social (SILVA, 1994). Nessa mesma perspectiva Salve e Silva (2009), na sua pesquisa sobre as representações sociais maternas sobre a introdução de alimentos complementares aos seus lactentes, conclui que as mães realizam um movimento de julgamento para tomada de decisão quanto à alimentação do seu filho e esse processo é a base de suas representações e experiências.

Na sociedade atual, há a valorização do leite materno como universal para a ciência, isso porque se superou a discussão sobre seus benefícios para o recém-nascido, mãe e família. Para tanto, é necessário ultrapassar os desafios e apreender o processo de aleitamento materno do ponto de vista das mulheres em diferentes situações de vida e os reais motivos que levam a 
não amamentar exclusivamente e assim a introdução de outros alimentos de forma precoce na dieta do recém-nascido.

Compartilha-se da ideia de Silva (1997), que mesmo a mulher conhecendo e valorizando o leite materno, o seu significado pode variar nos diferentes grupos sociais, tendo como referência o significado da amamentação na decisão materna de assumir riscos ou garantir benefícios, que está estreitamente relacionado ao que dispõem em termos econômicos e culturais. E ressalta que:

\footnotetext{
Assim, às práticas de amamentação atuais pressupõem a adesão de certos valores e comportamentos que podem ou não contribuir para o sucesso no processo de aleitamento materno, portanto a possibilidade de uma criança ser amamentada passa também por pré-requisitos que compõem o universo cultural de diferentes camadas sociais. (SILVA, 1997, p. 229).
}

Em anos de desenvolvimento de campanhas e propostas de incentivo ao aleitamento materno, desde idos de 1980, pode-se considerar que tanto os índices de amamentação melhoraram (ARAGAKI; SILVA; 2011), os índices socioeconômicos de brasileiros continuam em crescente melhoria (SHIMODA; SILVA; 2010), segundo dados governamentais, e também houve uma transformação de paradigma no que concerne a visão do processo de amamentação, envolvendo a subjetividade feminina, seu contexto e seu entorno social e de condições concretas de vida (MÜLER; SILVA; 2009).

No entanto, também como se apresenta neste texto, ainda há bolsões de miséria onde mulheres, crianças e famílias inteiras vivem em condições inaceitáveis, buscando a sobrevivência possível em meio ao que lhe resta de oportunidade de trabalho ou ocupação. Nesse contexto, que o estudo já referido, realizado por Abade e Pereira (2009), mostrou aspectos quantitativos que remetem a outros questionamentos, ou seja, enxergar uma realidade ainda não desvelada pelos números.

O perfil de amamentação das mulheres de Mangabeira, cujo estudo aqui apresentado pela pesquisadora suscita questionamentos que levam a pensar qual o significado que essas mulheres atribuem à amamentação, em meio a tanta carência e necessidade de superar, no dia a dia, sua busca pela 
subsistência. O que leva mulheres desse contexto, com alta vulnerabilidade social, a apresentar uma amamentação total em média, maior que a nacional, mesmo que deixem precocemente de amamentar exclusivamente seus filhos. Daí a pergunta desta pesquisa:

Qual é o significado e como vivenciam a amamentação e constroem esta prática em seu cotidiano de mulher e moradoras de uma comunidade com alta vulnerabilidade social no interior do estado de Alagoas? 


\section{OBJETIVOS}


Compreender o significado de amamentar para mulher moradora de uma comunidade com alta vulnerabilidade social no interior do estado de Alagoas.

Compreender como se desenvolve a prática de amamentação da mulher moradora de uma comunidade com alta vulnerabilidade social no interior do estado de Alagoas, em relação à amamentação. 
3 PRINCÍPIOS TEÓRICO-METODOLÓGICOS DA PESQUISA 


\section{PRINCÍPIOS TEÓRICO-METODOLÓGICOS DA PESQUISA}

Por conta da necessidade de compreender o significado do processo de amamentação de mulheres que vivenciam um cenário de extrema pobreza optou-se pela Metodologia qualitativa, por assim ser possível relacionar o significado e a intencionalidade própria dos atos dos sujeitos e suas relações em estruturas sociais em constantes transformações. Assim, esse tipo de abordagem metodológica preocupa-se em compreender a realidade social, tendo como base os sujeitos, as estruturas e significados acerca do objeto em estudo (MINAYO, 2010). Apesar de ser uma pesquisa essencialmente qualitativa, serão utilizados dados quantitativos com o intuito de descrever melhor o contexto do fenômeno, entendendo conforme Minayo (2010), que existe uma complementaridade entre essas estratégias metodológicas que, quando bem trabalhadas, podem aprofundar com maior fidedignidade o objetivo proposto para tal.

Alguns autores afirmam que, para uma pesquisa ser considerada qualitativa, deve apresentar a pergunta, ou o objeto da investigação; uma determinada postura teórica ou epistemológica; e uma correspondente estratégia para a obtenção das informações e sua análise (MARTINEZ; BOSI; 2004).

$\mathrm{Na}$ pesquisa qualitativa, o teor de qualquer enfoque é dado pelo referencial teórico no qual se apoia o pesquisador. A perspectiva teórica adotada guia o que o pesquisador qualitativo estuda, como ele a estuda e a interpreta (TRIVIÑOS, 1992).

Considerando os aspectos aqui já expostos e o objeto do estudo em questão, a opção pelos pressupostos do Interacionismo Simbólico sustentase na busca de significados para mulheres, em meio a uma realidade de vida que estar carregada de simbolismos, que permeiam as ações e definem o comportamento dessas mulheres e suas relações com objetos, pessoas e símbolos com os quais constroem seu mundo social (COULON, 1995; BLUMER, 1969). 


\subsection{INTERACIONISMO SIMBOLICO}

O Interacionismo Simbólico (IS) é entendido como uma teoria sobre o comportamento humano, que se focaliza no significado que os acontecimentos ou eventos têm para as pessoas no seu próprio ambiente. Assim é possível relacionar diretamente com o objeto deste estudo, partindo da necessidade de ampliar a compreensão do significado de amamentar para mães que convivem em um ambiente de pobreza, permitindo apreender, de forma mais profunda, a complexa interação das relações, que cercam o processo de amamentação, dentro dos padrões sociais estabelecidos por mulheres que sobrevivem, em sua maioria, da catação de produtos recicláveis no lixo.

O Interacionismo Simbólico é uma perspectiva teórica que se reporta em origem a clássicos da Sociologia do fim do século dezenove, em oposição às teorias sociológicas de caráter totalizante, como o Funcionalismo. Seus primeiros caminhos foram originalmente elaborados pelo filósofo e cientista social George Hebert Mead (1863-1931), mas é somente na década de 1930, no âmbito da sociologia norte-americana, por iniciativa do sociólogo Herbert Blumer (1900-1987), que foram desenvolvidas as primeiras formulações teóricas do Interacionismo Simbólico, sendo empregadas no estudo do comportamento coletivo. O foco do Interacionismo Simbólico concentra-se, justamente, nos processos de interação social - que ocorrem entre indivíduos ou grupos - mediados por relações simbólicas (CHARON, 2010; HAGUETTE, 2007).

A perspectiva do Interacionismo Simbólico vai para além das ações sociais, condicionadas pelo arcabouço normativo da sociedade, pois, para essa teoria, há uma enorme variedade de interações sociais que ocorrem de modo a formar coletividades separadas, que levam à constituição de determinados grupos sociais, cada um com suas regras e normas de conduta, validadas e aceitas pelos indivíduos que os compõem. Assim, as interações sociais são processos dialéticos, pois os indivíduos constroem os grupos e as coletividades sociais dos quais fazem parte, mas, ao mesmo tempo, esses 
grupos e coletividades interferem na conduta do indivíduo (BLUMER,1969).

Com base nessas considerações, pode-se aplicar as três premissas básicas, de maneira a ter o seguinte quadro: a ação dos atores é derivada da significação; essa significação deriva ou surge das interações sociais; por fim, as significações são empregadas pelos atores sociais nas interações sociais grupais, que, por sua vez, modificam as próprias significações. Além disso, diz Blumer (1969), as faculdades humanas, tais como o pensamento e a linguagem, interagem reciprocamente com as três premissas mencionadas.

Assim, desvelando essas ideias, pode-se dizer que a comunicação é feita por meio da linguagem verbal ou gestual, empregada pelos atores sociais, pode ser considerada um elemento constante e fundamental nos processos de interação social. O ato social é o comportamento externo real e observável, condicionado por processos complexos de interações sociais. Quando ocorre uma interação social, o indivíduo é estimulado a acionar sua autopercepção, que pode ser entendida como uma operação mental em que o indivíduo empenha-se num processo comunicativo consigo mesmo, na interpretação dos símbolos externos que estão a sua volta, no contexto em que ele se encontra (BLUMER,1969).

Na segunda etapa, pode ocorrer a ação prática ou comunicativa, que também é influenciada ou derivada da situação, ou do contexto em que o indivíduo se encontra. Por sua vez, a reação dos outros indivíduos envolvidos no mesmo processo de interação conduz a uma nova reinterpretação simbólica. Dessa perspectiva, os significados são construídos e reconstruídos (BLUMER, 1969).

Portanto, o Interacionismo Simbólico desenvolve um esquema analítico da sociedade e das condutas humanas, que envolve ideias básicas relacionadas a grupos humanos, ou sociedades, interação social, objetos, o ser humano como ator, a ação humana e as interconexões das linhas de ação, efetivando uma microanálise, por estudar as interações interindividuais, a negociação individual e a reação do outro, levando às atividades interpretativas, determinadas pela situação e interação das pessoas (HAGUETTE, 2007). 
Para uma melhor compreensão dessa perspectiva teórica, faz-se necessária a compreensão de alguns conceitos pertinentes, tais como coisas, símbolos, mente, self, linguagem, sociedade, autointeração, ação humana e atividade grupal, descritos da seguinte forma segundo Blumer (1969):

As coisas incluem o que o ser humano pode observar em seu mundo físico e, conforme o significado que essas coisas têm para o ser humano, suas ações são dirigidas a essas coisas. Portanto é tomado como base o seu significado.

Os símbolos são o que vemos e como os interpretamos, e o nosso mundo é de símbolos, a nossa realidade é simbólica; por meio da interação simbólica que se atribui os significados e se desenvolve a realidade onde se age (CHARON, 2010). Para Mead (1972), um gesto compartilhado é um símbolo significante, e é na sociedade que nascem os símbolos significantes do grupo. Já o significado surge da interação de duas pessoas, ou seja, o significado que uma coisa tem para uma pessoa cresce da forma como as outras pessoas agem em relação a ele, em relação a essa coisa (BLUMER, 1969).

A ênfase na concepção interacionista de significado é sobre a interpretação consciente; as coisas passam a ter significado para a pessoa quando esta as considera conscientemente, reflete e pensa sobre o objeto, ou o interpreta (HAGUETTE, 2007).

A pessoa que responde, organiza sua resposta, tomando por base o que os gestos significam. A pessoa que apresenta os gestos como indicações do que está planejando fazer, toma por base aquilo que quer que o respondente faça ou compreenda. Com efeito, o gesto tem significado tanto para a pessoa que faz como para a para quem é dirigido. A interação simbólica, que envolve o processo de interpretação da ação, procura compreender o significado da ação de cada outro (BLUMER,1969).

A natureza do próprio ser humano concebe o self, sendo social, por meio da interação com os significados do outro, na relação com o mundo, para permitir o seu controle, direção e manipulação da própria vida. É formado pelo $\mathrm{Eu}$ e Mim, sendo o Eu a resposta para as atitudes do outro, o lado impulsivo, espontâneo e que não age, porque interage simbolicamente 
com si próprio. O Mim é a organização das atitudes, é o outro generalizado, composto de padrões organizados, consistentes, compartilhados com outros (CHARON, 2010).

A mente é a ação simbólica para o self e surge da interação com outros, dependendo de ambos os selfes e símbolos (CHARON, 2010).

A linguagem é composta de instrumentos usados por indivíduos, para ordenar a experiência. É empregada para discriminar, generalizar, fazer sempre a distinção no ambiente. Assim, o mundo é literalmente dividido por significados que se usa por meio da linguagem (CHARON, 2010). A linguagem surge e modela o comportamento (BAZILLI, 1998).

Os interacionistas definem a sociedade como constituída de indivíduos que interagem uns com os outros, quando as atividades dos membros ocorrem como resposta de um ao outro, ou em relação ao outro (BAZILLI, 1998).

Pode-se, assim, dizer que o processo interpretativo, por meio da autointeração, leva a uma re-significação do vivido, em que os valores interferem no significado que as coisas têm para a pessoa (BLUMER, 1969).

A autointeração, portanto, emerge da interação social, em que outras pessoas estão definindo uma pessoa para si. Para Mead, isso acontece, quando a pessoa se vê pelo lado de fora, colocando-se na posição do outro e vendo-se ou agindo em relação a si nessa posição (BLUMER,1969).

A ação humana é vista como um resultado formado da autointeração; é construída por meio das indicações que a pessoa faz a si e interpretação do que indica para agir. A pessoa identifica que quer estabelecer uma meta, mapeia uma linha de comportamento, observa e interpreta as ações dos outros, dimensiona a sua situação, checa-se, elabora o que fazer com os outros pontos (BLUMER,1969).

Mead (1972) dividiu a ação do ser humano em quatro estágios: impulso, percepção, manipulação e consumação, e definiu que a essência da ação é causada pela decisão tomada pela pessoa, ativamente por meio desses estágios, como segmentos da ação. As regras e normas para as ações dos 
sujeitos manifestam-se pelas da negociação de significados, de sanções, de hierarquias e das próprias normas sociais.

A atividade grupal baseia-se no comportamento cooperativo que surge através de cada pessoa, em perceber a intenção dos outros e construir a sua resposta baseada naquela intenção, pois o comportamento não é uma resposta direta às intenções dos outros, que é transmitida pelos gestos tornados simbólicos, passíveis de interpretação (BLUMER, 1969).

O Interacionismo Simbólico, como princípio metodológico, defende a noção de que, para compreender o mundo, é necessário analisá-lo, com base nas ações e interações de seus participantes (HAGUETTE, 2007).

Assim, para Blumer (1969), o estudo exploratório é o meio para conseguir-se um conhecimento extenso e profundo da esfera da vida social e de desenvolver e acentuar as investigações.

Segundo Coulon (1995), essa perspectiva privilegia o ponto de vista dos sujeitos e trouxe pela primeira vez às ciências sociais um lugar teórico para o sujeito social como intérprete do mundo. Pondo em prática uma abordagem que elucida os significados que os próprios sujeitos põem em prática para construir seu mundo social.

Para alcance da compreensão plena do processo social, o investigador precisa apoderar-se dos significados que são experenciados pelos participantes, em um contexto particular, já que esse é um dos elementos mais importantes na compreensão do comportamento humano, das interações e dos processos (JEON, 2004). Esse processo é melhor traduzido nas palavras de Blumer (1969, p. 40).

Como pode alguém aproximar-se da área e escavá-la? Isto não é uma questão simples de aproximar-se de determinada área e olhar para ela. É um trabalho exaustivo, que requer uma ordem elevada (sondagem), tentativa cuidadosa e honesta, imaginação criativa e disciplinada, recursos e flexibilidade no estudo, uma ponderação dos resultados e uma constante disposição para testar e reorganizar as visões e imagens da área.

Assim, a pesquisa interacionista tem por objetivo entender o mundo pelas das experiências vividas por meio do ponto de vista daqueles que nele vivem. Esta perspectiva aborda a organização sob uma posição 
predominantemente subjetivista, procurando entender os significados existentes nas organizações. A abordagem subjetivista prevê a filtragem do conhecimento por meio do pesquisador e, portanto, fortemente impregnado pelas forças cognitivas e culturais.

A teoria interacionista vê a pesquisa como uma categoria simbólica baseada na interação. Portanto, a melhor maneira para captar a realidade é aquela em que se possibilita ao pesquisador pôr-se no papel do outro, olhando o mundo pela ótica dos participantes.

Blumer (1969) defende uma metodologia distinta para o estudo do homem; procura tornar a sociedade moderna inteligível; procura perceber a realidade social por meio de conceitos sensibilizantes, que buscam expressar o caráter processual da realidade; concebe a natureza do comportamento humano como imprevisível e indeterminado; concebe o self e a sociedade como processos dinâmicos; admite a existência da interação simbólica, característica dos humanos, e da interação não simbólica (ou conversação de gestos).

Quanto à forma de operacionalização desses conceitos, Blumer (1969) critica a metodologia convencional por utilizar meios de estabelecer a validade empírica de certos estudos por meio de esquemas que ele julga inadequados para captar o caráter específico do objeto de estudo, como pode ser melhor destacado seu texto a seguir:

\footnotetext{
Muitos procedimentos, como os que sublinham a necessidade do emprego de técnicas estatísticas e quantitativas, são inadequados, pois abordam um aspecto limitado do ato completo da investigação científica ignorando outros, como as premissas, os conceitos, etc. (BLUMER, 1969, p. 20).
}

Dessa forma, ele propõe uma posição metodológica para o interacionismo simbólico, na qual defende a noção de que, para compreender o mundo, é necessário analisá-lo em termos das ações e interações de seus participantes. "Para a ciência empírica, a 'realidade' só existe no mundo empírico, no qual se devem buscá-la e verificá-la [...]" (BLUMER, 1969, p. 16). 
Como esclarece Jeon (2004), a concepção de Blumer é de que o pesquisador deve ser capaz de interagir ativamente com as pessoas que estão sendo pesquisadas e de ver as coisas do seu ponto de vista e no seu contexto natural. Por conseguinte, quando adota a abordagem interacionista, o pesquisador precisa estar ativamente engajado no mundo em estudo e empreender uma análise de suas partes fundamentais, por meio das técnicas de exploração e inspeção, que são explicitadas respectivamente por Blumer, conforme se segue: $\mathrm{O}$ estudo exploratório é o meio para conseguir um conhecimento extenso e profundo da esfera da vida social e de desenvolver e acentuar a sua investigação. Por seu caráter reflexivo, não está sujeito a nenhum conjunto de técnicas em particular, pode recorrer à observação direta, entrevistar pessoas, obter informações sobre a vida real, utilizar cartas e diários, consultar documentos públicos e organizar discussões de grupo. A finalidade da investigação exploratória é traçar um quadro em estudo, tão completo e preciso quanto permitem as condições vigentes (BLUMER, 1969).

A inspeção consiste em examinar o elemento analítico dado, considerando-o de diferentes ângulos, estabelecendo diversas perguntas e examinando-as novamente; em outras palavras, um exame detido e profundo. A exploração e a inspeção representam a descrição e a análise e correspondem ao que se denomina investigação naturalista, um processo destinado a abordar o mundo empírico em seu caráter natural e contínuo, em lugar de se limitar a uma simulação desse mundo, uma abstração ou a sua substituição por uma imagem pré-estabelecida (BLUMER, 1969).

Portanto, para o desenvolvimento de um estudo que visa a compreender os significados de mulheres que vivem em condições de iniquidades sociais tão extremas, o uso dos pressupostos do Interacionismo Simbólico, como referencial teórico, pôde dar respostas para a elucidação dos significados e suporte para compreender as ações dessas mulheres durante o processo de amamentação. Assim:

- As ações dessas mulheres, que conformam o processo de amamentação ou a opção pelo desmame do filho, estão 
relacionadas ao significado que a experiência de amamentar tem para elas.

- O significado de amamentar é advindo da interação que essas mulheres estabelecem consigo e com outros elementos do seu contexto, na situação de serem mães numa vivência de iniquidades sociais.

- Esses significados são modificados por um processo interpretativo, usados por elas em sua interação com o seu ambiente.

Dessa forma, considera-se que os pressupostos do teóricos do Interacionismo Simbólico permitiram que se aprofundasse na busca de compreender tal significado, em meio à sua realidade de vida, percebendo que esta é carregada de simbolismos que permeiam as ações e definem comportamentos em relação ao modo de conduzir a vida de cada uma dessas pessoas, definindo o seus caminhos no processo de amamentar. 


\subsection{MODELO TEÓRICO - "Pesando Riscos e Benefícios"}

Não são muitos, ainda, os estudos que buscam entender o processo de aleitamento materno do ponto de vista das mulheres e famílias. O estudo qualitativo de Silva (1997) teve como desafios compreender os significados de amamentação para mulheres e como esses significados intervinham no processo de decisão de amamentar ou não, realizado com base nos pressupostos do Interacionismo Simbólico e da Teoria Fundamentada nos Dados. Este estudo chegou ao desenvolvimento do modelo teórico, "Pesando Riscos e Benefícios" que sistematiza o processo e os elementos que a mulher utiliza para tomar a decisão de amamentar.

O modelo permite compreender que o comportamento da mulher, em relação à amamentação, é determinado, em parte, por concepções formadas já na gravidez, por meio de crenças, conhecimentos, sentimentos e experiências vivenciadas antes mesmo da sua pratica de amamentação, tendo sua definição concreta elaborada durante a experiência de amamentar. Nesse processo foram identificados dois fenômenos que explicam a vivência da mulher na trajetória de torna-se mãe/nutriz, sendo elas: Estando Grávida e Vivenciando a Prática de Amamentar.

$\mathrm{O}$ primeiro fenômeno, diz respeito à vivência da gestação e mostra a mulher num movimento dos acontecimentos sejam eles sequenciais ou concomitantes, percebe-se como reformuladora de sua identidade diante da tensão dos novos papeis que passará a desempenhar. Assim, a percepção dessa experiência transcende a gravidez como processo fisiológico e social, passando a ser caracterizada pela percepção que a mulher tem de si e dos demais elementos que compõem seu ambiente e sua relação com o filho, a família e as mudanças advindas da presença dele.

O segundo fenômeno, "Vivenciando a Prática de Amamentar" demonstra que a pratica da amamentação não depende exclusivamente de uma decisão prévia ou de conhecimentos sobre o assunto, mas também de interações vivenciadas pela nutriz, dentro do seu contexto.

O fenômeno central do processo de amamentação foi identificado como "Pesando Riscos e Benefícios": “[...] Onde a experiência da 
amamentação é vivida pela mulher como um processo avaliativo e valorativo, onde ela avalia sua capacidade de amamentar, seus sentimentos e toma a decisão sobre os caminhos da amamentação" (SILVA, 1997, p. 109).

Assim, também, como pressupostos teóricos para análise dos dados usou-se, o modelo "Pesando Riscos e Benefícios", que auxiliou a compor a experiência das mulheres vivenciando o mesmo processo de amamentar, porém em contexto de extrema pobreza. 


\subsection{PROCEDIMENTOS METODOLÓGICOS}

\subsubsection{Contexto da pesquisa}

O estudo foi realizado no denominado Conjunto ou Comunidade da Mangabeira (favela do Lixão), localizada na região norte da cidade de Arapiraca, interior de Alagoas, nas imediações do Lixão da cidade, para onde é destinada a maior parte dos resíduos sólidos do município. A favela do Lixão surgiu juntamente com o crescimento do deficit habitacional do município. A ocupação da área data aproximadamente da década de 1920, com a instalação do "lixão", ampliando-se a partir de 1997, com a construção das primeiras células do aterro sanitário, quando, de fato, houve um maior adensamento populacional (PREFEITURA ARAPIRACA, 2007).

Por meio da geração de renda que a catação do lixo permite, famílias de baixa renda encontram, na área, uma forma de subsistência, ocupando "lotes" de forma aleatória, gerando um bairro desordenado e com graves problemas sociais, ambientais e físicos.

Com o notório aumento do número de barracos, justificado pelo crescimento da cidade de Arapiraca, esta vem sendo vista como um polo aglutinador de desenvolvimento para o interior do estado de Alagoas. A Prefeitura, com recursos do Programa Minha Casa Minha Vida, lançado pelo Governo Federal, no ano de 2009, entregou casas para as famílias que moravam em barracos do Conjunto Mangabeira. Então passaram a residir no Residencial Brisa do Lago, em 2011, distante da Mangabeira cerca de 30 $\mathrm{km}$. Os barracos das famílias que passaram a residir no Brisa do Lago, receberam novas famílias, provenientes de cidades vizinhas. Estas, em sua maioria, são famílias de catadores de outras regiões do estado. E as famílias de catadores, moradoras do novo conjunto habitacional, passaram a ir diariamente de suas casas novas para o trabalho no lixão, mas, devido à longa distância unida às dificuldades e aos gastos com transporte, algumas voltaram a ocupar novos ou antigos barracos durante o dia, retornado à sua casa à noite, e outras venderam suas casas novas e retornaram, em definitivo, para a Mangabeira. 
Em 2011, a comunidade compreendia aproximadamente 200 barracos de lona e papelão, tendo um total de moradores superior a 800 pessoas, e seis ruas com 350 casas onde moradores fixaram-se e são provenientes, em sua maioria, da zona rural de Arapiraca, de municípios circunvizinhos, ou de outros estados. Esses dados foram confirmados em janeiro de 2014, pela líder Comunitária e não apresentam mudanças significativas. Esses moradores encontram, na catação do lixo, a única fonte de geração de renda possível para a subsistência das famílias. As casas são localizadas a uma distância de 200 metros do despejo de lixo.

Essa comunidade foi escolhida para o desenvolvimento deste trabalho, por já ser campo de atuação do Curso de Enfermagem da Universidade Federal de Alagoas (UFAL) - Campus Arapiraca, desde 2007, com o desenvolvimento, por parte da pesquisadora, de atividades de ensino, com aulas práticas da disciplina Saúde Ambiental e pesquisas de iniciação científica, junto à comunidade.

\subsubsection{Sujeitos da pesquisa}

Foram convidadas a participar do estudo mulheres moradoras da comunidade Mangabeira que trabalhavam no lixão, ou tinham sua renda familiar composta pelo trabalho nesse local. Todas tiveram filhos e passaram pela experiência de ter amamentado por qualquer tempo, sem restrição de idade e paridade.

A dimensão da amostra somente foi determinada ao longo do processo de investigação, pois são os dados que desvendam o problema emergente, remetendo, assim, aos locais e aos sujeitos a serem pesquisados posteriormente (SILVA, 1994; ANGELO, 1989). Portanto, a inclusão de cada mulher foi sendo feita à medida que ocorria cada entrevista, que, somada à análise dos dados, determinava a necessidade da continuidade de coleta de dados.

Conforme Minayo (2010), alguns cuidados devem ser tomados com o processo de amostragem, com a finalidade de refletir a totalidade de suas múltiplas dimensões: privilegiar os sujeitos que detêm as informações e 
experiências que o pesquisador deseja conhecer; considerar um número suficiente para a reincidência das informações; escolher um conjunto de informantes que possibilite a apreensão de semelhanças e diferenças.

Dessa forma, conforme os dados foram sendo coletados e analisados, sinalizavam para focalização e maior detalhamento de alguns aspectos que deveriam ser esclarecidos e aprofundados, sempre na busca da compreensão do significado de amamentar para essas mulheres em seu contexto de vida.

No momento em que se percebeu a saturação e consolidação dos dados, foi considerado o encerramento da coleta, que ocorreu com a inclusão da $35 .^{\text {a }}$ mulher. Os dados foram coletados, pela própria autora deste trabalho, no período de julho de 2012 a julho de 2013.

\subsubsection{Obtenção dos Dados para a Pesquisa}

A seleção de técnica e instrumento para obtenção dos dados foi definida em função da pretensão de apreender, de forma ampla, a realidade dessas mulheres. Para a realização deste estudo, foi utilizada como estratégia para obtenção de dados qualitativos a entrevista aberta em profundidade, porém utilizou-se, no inicio da entrevista, de um formulário com dados de cunho quantitativos (Apêndice A).

Esse formulário de coleta de dados de identificação socioeconômica foi estruturado de forma a organizar dados quantitativos de identificação materna e familiar, com a finalidade de fazer o levantamento de características biológicas, sociais e econômicas da mãe, da criança e da família.

A entrevista em profundidade é uma técnica qualitativa que explora determinado assunto mediante a procura de informações, percepções e experiências dos informantes para analisá-las e apresentá-las de forma estruturada. Dessa forma, o entrevistador pode ajustar as suas perguntas livremente, além da flexibilidade que a fonte tem para definir os termos de resposta. A entrevista aberta é utilizada, quando o pesquisador deseja obter o maior número possível de informações sobre determinado tema, segundo a visão do entrevistado, e também para obter um maior detalhamento do 
assunto em questão. Ela é utilizada, geralmente, na descrição de casos individuais, na compreensão de especificidades culturais para determinados grupos e para comparabilidade de diversos casos (MINAYO, 2010).

Assim, inicialmente, foram realizadas pela pesquisadora visitas à comunidade, com a finalidade de identificar as mulheres que eram potencialmente sujeitas do estudo junto à líder comunitária da área. Nessa primeira visita, houve uma conversa com as pessoas da escola, da creche, do lixão e uma visita a algumas mulheres, para, uma melhor interação. Nesse primeiro encontro, foram agendadas as primeiras visitas para início das entrevistas.

Todas as entrevistas foram realizadas no domicilio das entrevistadas, local que permitiu segurança e liberdade, uma vez que as participantes mostraram-se dispostas a colaborar com o estudo. Na chegada às casas das mulheres, algumas estavam ocupadas em atividades domésticas. Mesmo assim, a pesquisadora sempre foi atendida com muita presteza e simpatia por todas, sem nenhum fator que pudesse atrapalhar o processo da entrevista.

A entrevista sempre era iniciada com a apresentação da pesquisadora, seguida de esclarecimentos sobre a pesquisa e aplicação do formulário com dados quantitativos. Sendo apresentada a leitura do Termo de Consentimento Livre e Esclarecido (TCLE), (Apêndice B), com todos os esclarecimentos feitos, seguidos da concordância e assinatura, com uma cópia entregue à mulher; e outra, permaneceu sob guarda da pesquisadora, não havendo nenhuma recusa à participação do estudo.

Nessa estratégia de coleta de dados, o investigador tem questões para serem respondidas, com relativa flexibilidade, tendo-se claro que não há receitas prontas. Com isso, a entrevista, era iniciada, por meio de uma pergunta ampla: "Fale-me sobre sua vida". A pergunta faz com que as mães contem sobre sua história de vida pessoal e familiar. Na sequência, era indagada sobre a questão central: "Fale-me sobre como foi, ou está sendo, a sua experiência de amamentar seu filho (a)". No desenvolver da entrevista, a pesquisadora sempre estava atenta, para garantir uma condução adequada, no sentido de mediar às contingências que pudessem afetar a entrevista. As 
primeiras entrevistas nortearam a elaboração de questões mais estruturadas, que passaram a orientar as entrevistas seguintes, com a análise concomitante.

Como as casas ou barracos das mulheres são pequenos, e as divisórias de cômodos, muitas vezes de tecido, quatro entrevistas foram concluídas em duas visitas, pois, quando se percebia que a presença de algum membro da família podia dificultar o processo, agendava-se com a mulher outro dia para nova visita e conclusão da entrevista.

\subsubsection{Análise de dados descritivos}

Os dados de cunho quantitativo foram organizados em planilhas eletrônicas e analisados, utilizando o programa Microsoft Office Excel. Os resultados foram apresentados de forma descritiva, ou em tabelas, utilizando frequências absolutas, percentuais e médias. A caracterização quantitativa do grupo não obedeceu a objetivos estatísticos, mas para enriquecer a compreensão dos processos e significados da temática para o grupo estudado. Por esse caminho, buscou-se conhecer e compreender profundamente a realidade estudada. Para caracterizar a situação de amamentação/alimentação da criança, foram utilizadas as seguintes categorias propostas pela OMS, (2010), em que foi acrescentada a categoria Desmame (D):

- Aleitamento materno exclusivo (AME): a criança recebe somente leite materno, direto do seio ou ordenhado, ou leite humano de outra fonte, sem outros líquidos ou sólidos, com exceção de gotas ou xaropes contendo vitaminas, sais de reidratação oral, suplementos minerais ou medicamentos.

- Aleitamento materno predominante (AMP): a criança recebe, além do leite humano, água ou bebidas à base de água (água adocicada, chás, infusões), sucos de frutas, e fluidos rituais.

- Aleitamento materno (AM): a criança recebe leite humano (direto da mama ou ordenhado), independentemente da quantidade e de estar recendo ou não outros alimentos. 
- Aleitamento materno complementado (AMC): para entrar nessa categoria a criança deve estar recebendo leite humano e, necessariamente, alimentos sólidos ou semissólidos. Ela pode estar recebendo, além desses alimentos, outros alimentos, incluindo leites de outras espécies. Com a finalidade de complementá-lo e não de substituí-lo.

\subsubsection{Análise de dados qualitativos}

Como o processo de análise de dados deu-se de forma concomitante, as entrevistas foram transcritas tão logo fosse possível, dando-se preferência em ser realizadas no mesmo dia em que foram feitas.

A entrevista deve ter formas eficientes de registro, pois seu sucesso depende de um registro completo, acurado e detalhado das anotações de campo. Bourdieu (2003) refere que uma transcrição de entrevista não é somente um ato mecânico de passar para o papel o discurso gravado do informante, pois, de alguma forma, o pesquisador tem que apresentar os silêncios, os gestos, os risos, a entonação de voz do informante durante a entrevista.

Desde a primeira entrevista, percebeu-se, pela fala das mulheres, uma linguagem própria, com uso de termos característicos ao grupo, e muitas frases pareciam ter seu sentido textual modificado, em função de uma dificuldade de expressar seus pensamentos, isto é de expor e refletir sobre seu eu e seu contexto de vida.

Para entender melhor as entrevistas foi preciso compreender que a oralidade como prática social desenvolve-se naturalmente em contextos informais do dia a dia. Assim, percebemos que as pessoas desenvolvem domínios discursivos conforme seu contexto, e para a análise de dados qualitativos, a fala é, quase sempre, o principal objeto a ser analisado. Nessa linha de pensamento, pode-se perceber que, mesmo em um grupo com baixa escolaridade, com falas permeadas de termos, com um grande conjunto de elipses, repetições, ritmo de fala predominantemente coeso, a fala está em ordem. Portanto, as produções discursivas são eventos complexos 
constituídos de várias ordens simbólicas que podem ir além do recurso estritamente linguístico. Assim, toda atividade discursiva situa-se a, grosso modo, no contexto da fala ou da escrita (MARCUSCHI, 2007).

Esse mesmo autor aponta que a língua é um dos bens sociais mais preciosos e mais valorizados por todos os seres humanos em qualquer época, povo e cultura. Mais do que um simples instrumento, a língua é uma prática social que produz e organiza as formas de vida, as formas de ação e as formas de conhecimento. É por meio dela que é possível cooperar intencionalmente, e não apenas por instinto. Mais do que um comportamento individual, ela é atividade conjunta e trabalho coletivo, contribuindo de maneira decisiva para a formação de identidades sociais e individuais. Portanto, ao analisar o conteúdo das falas das mulheres em estudo foi possível perceber suas particularidades e assim poder compreender seus significados (MARCUSCHI, 2007). Essas premissas conferem às pesquisas qualitativas uma segurança que permite ao pesquisador garantir confiabilidade em seu processo de análise.

Assim, cabe ao pesquisador utilizar um método de análise de dados que permita desvendar o fenômeno a ser estudado e assim foi feito, ao organizar os dados, segundo a proposta do Discurso do Sujeito Coletivo (DSC) de Lefèvre e Lefèvre (2005).

\subsubsection{Estratégia metodológica - Discurso do Sujeito Coletivo}

A investigação qualitativa é caracterizada como uma abordagem de alto grau de complexidade, à medida que se aprofunda nas interpretações e decifra seus significados, possuindo procedimentos de cunho racional e intuitivo para a melhor compreensão da complexidade dos fenômenos individuais e coletivos (PAULILO, 2008).

A subjetividade e o simbolismo permeiam o contexto social, tornando-se essencial à análise cuidadosa deles para a realização da Pesquisa Qualitativa. A começar dessas premissas, opçtou-se pelo uso do Discurso do Sujeito Coletivo, que é uma estratégia metodológica que vem sendo amplamente difundida em pesquisas científicas, trazendo uma 
mudança significativa na qualidade e na eficiência, ao utilizar a abordagem discursiva, com o objetivo de tornar mais clara, organizar e apresentar dados qualitativos de natureza verbal.

O DSC é um discurso-síntese, elaborado com fragmentos de discursos de sentidos semelhantes reunidos em um só discurso. Assim, a organização de depoimentos resgata o sentido das opiniões coletivas, levando a um conjunto de discursos-síntese, construídos em primeira pessoa, a começar pelos trechos da fala de cada indivíduo, tantos quanto julgue ser necessários para expressar uma dada figura, ou seja, um dado pensar social de um determinado fenômeno (LÈFREVE;LÈFREVE; 2006).

O processo para a construção dos Discurso do Sujeito Coletivo envolve a identificação de figuras metodológicas do DSC, que são chamadas também de operadores. Quais sejam: Expressões-Chave; Ideias Centrais; Ancoragens. As Expressões-Chave são trechos do discurso que devem ser destacados pelo pesquisador em cada depoimento, e que revelam a essência do conteúdo do discurso. As Ideias Centrais descrevem, da maneira mais sintética e precisa, os sentidos presentes nas ExpressõesChave e também no conjunto de discursos de diferentes sujeitos, que possuem semelhança de sentido, possuindo uma função discriminadora e classificatória e permitindo identificar e distinguir os vários sentidos, ou posicionamentos, contidos nos depoimentos. Já as Ancoragens são expressões sintéticas que descrevem as ideologias, os valores e as crenças presentes nos depoimentos individuais, ou agrupados, configurados como afirmações genéricas enquadradas em circunstâncias particulares (LÈFREVE; LÈFREVE; 2005).

Os Discursos de Sujeitos Coletivos não anulam os conteúdos dos depoimentos, já que o objetivo não é somente desenvolver uma soma matemática, mas também um discurso coletivo que gere um posicionamento, e um sentido em que a opinião individual de cada depoimento esteja garantida e preservada. No Discurso do Sujeito Coletivo, dentro de uma única categoria, vários conteúdos e argumentos que compõem uma mesma opinião, ou um mesmo posicionamento, são compartilhados por um conjunto de pessoas. Esses distintos conteúdos e 
argumentos podem ser mantidos em conjunto num discurso, porque este remete praticamente a uma única ideia ou opinião (LÈFREVE;LÈFREVE; 2005).

Segundo Lèfreve e Lèfreve, (2005), é possível que uma mesma pessoa apresente mais de uma ideia central para cada depoimento ou resposta. As partes desse depoimento em que estão presentes ideias diferentes devem ser tratadas como um depoimento diferente. Dessa maneira, considera-se uma mesma pessoa como portadora de mais de uma resposta.

É considerável que, ao utilizar a técnica do DSC, crie melhores condições de verificar como os sujeitos veem e vivenciam o objeto do estudo em questão, pois, diante da elucidação dos discursos, foi possível compreender o significado de amamentar para mulheres, em um contexto de pobreza, tendo como base o Interacionismo Simbólico e o modelo "Pesando Riscos e Benefícios".

As entrevista foram codificadas como Mulher 1, Mulher 2 e, assim, sucessivamente até a Mulher 35, a fim de garantir o anonimato. Incialmente cada transcrição era organizada em um quadro, com duas colunas. As entrevistas foram dispostas na primeira coluna e, na segunda coluna, as expressões-chave (EC), contidas em cada relato transcrito. As expressõeschave correspondem à essência ou à "matéria-prima" da entrevista. São trechos selecionados do material verbal, que melhor descrevem o conteúdo essencial da fala da entrevistada. Portanto, são as frases mais significativas das falas, que expressam o pensamento dessas mulheres, vinculados ao objeto do estudo.

Em seguida, as expressões-chave foram identificadas em similaridade, dando origem às ideias centrais de cada entrevista que norteiam os discursos. A ideia central é uma figura sintética, ou seja, uma abstração da palavra concreta que descreve os sentidos, as razões, presentes no material verbal das expressões-chave.

Após atenta leitura, as ideias centrais foram organizadas por sentidos semelhantes ou complementares, dando origem a vários discursos do sujeito 
coletivo, que traduzem o significado daquela questão para o grupo de pessoas entrevistadas.

Depois de discursos estruturados, construiu-se um diagrama, para organizar os discursos, seguindo um fluxo de ideias contidas em cada DSC, dos quais originaram temas, de forma a responder aos objetivos da pesquisa, na busca da identificação do fenômeno.

\subsubsection{Aspectos éticos da pesquisa}

O projeto foi aprovado em 19/06/2012 pelo Comitê de Ética e Pesquisa da Escola de Enfermagem da USP, sob o processo de n. ${ }^{\text {o: }} 39252$ (Anexo1). Todas as mulheres foram abordadas quanto ao seu desejo e consentimento da utilização dos dados levantados na entrevista, para a realização da pesquisa. Em todas as entrevistas, houve o pedido de permissão para gravação. Após o esclarecimento dos objetivos do estudo e anuência das mulheres, foi apresentado o Termo de Consentimento Livre Esclarecido, para leitura e para ser assinado livremente, ou por seu responsável legal, nos dois casos de adolescentes menores de 18 anos que foram entrevistadas.

Foram asseguradas as garantias de anonimato, sigilo e de que os dados serão utilizados somente para fins científicos, cujos resultados serão públicos em periódicos científicos, ficando assegurado o desejo da não participação na pesquisa, conforme legislação em vigor, ditada pelo Conselho Nacional de Saúde/Ministério da Saúde (BRASIL, 2006). 
4 ANÁLISE E DISCUSSÃO DOS 


\section{ANÁLISE E DISCUSSÃO DOS DADOS}

A análise dos dados obtidos junto às mulheres deste estudo possibilitou a compreensão do contexto de suas experiências, inseridas e delineadas no dia a dia da pobreza e de suas relações familiares e de subsistência. Nessa trajetória de conhecer os significados e o cotidiano foram construídas categorias aqui denominadas Temas, que apresentam as mulheres quanto às suas características biológicas e sociais, da família e da comunidade. Também, apresentam-se as experiências dessas mulheres em seu ciclo de reprodução e no cuidado com os filhos.

Uma primeira abordagem da vivência da mulher mostra parte de sua trajetória de vida, anseios, demandas, esperanças e sua inserção no grupo social a que pertence, a interface com membros da sua comunidade, a prática da solidariedade e o enfrentamento da pobreza, por vezes solitário e doloroso. Nesse cenário, o grande risco percebido por sua vida é representado pela fome que assume significado de dor e de divisor de águas entre a pobreza e a miséria. Também, é demostrada com base na combinação de dados quantitativos e qualitativos, uma visão do exercício da amamentação, levando a melhor compreensão do perfil do aleitamento materno praticado pelas mulheres. Esse conteúdo descritivo, prepara a apresentação dos significados mais contundentes da experiência de amamentar dessas mulheres, expressos nos demais DSC.

No cenário de demandas crescentes de sobrevivência, a amamentação aparece como fonte de alimento essencial que vai se mostrando como prática e significa "o recurso para matar a fome da criança, nem bom, nem ruim, como experiência para a mulher, mas encarado como ato normal", e previsível no exercício da maternidade que pode ser substituído quando a mulher tem algum outro alimento a oferecer para o filho.

Estas relações e sua construção podem ser compreendidas pelos três temas construídos pelos DSC e reunidas sob denominação: Amamentação : um recurso contra a fome, nem bom, nem ruim - Normal. 


\subsection{AS CARACTERÍSTICAS DAS MULHERES, DA FAMILIA E DA COMUNIDADE}

Conforme se apresenta na Tabela 1, houve a participação de 35 mulheres, com idade entre 17 e 67 anos, com média de 36,2 anos, em sua maioria, adultas moradoras da comunidade Mangabeira. Estudo de Porto, et al. (2004), realizado com catadores de materiais recicláveis que atuavam em um aterro metropolitano do Rio de Janeiro, Brasil, também encontrou grande elasticidade na distribuição da idade (8-75 anos, média de 44 anos) em uma população de catadores. Essa variação etária, ou seja, mulher jovem, adulta e idosa, trouxe a este estudo, diferentes olhares que se interligam e interagem no contexto de vida das mulheres dessa comunidade, emergindo o significado do processo de amamentação de forma mais profunda, preservando os significados individuais em uma apresentação coletiva.

Tabela 1- Distribuição das mulheres moradoras da Comunidade Mangabeira, segundo a idade, Arapiraca, 2014

\begin{tabular}{l|l|l}
\hline Idade em anos & Mulheres & $\mathbf{\%}$ \\
\cline { 2 - 3 } & $\mathbf{N}$ & 5,7 \\
\hline $15-19$ & 2 & 34,3 \\
\hline $20-29$ & 12 & 20,1 \\
\hline $30-39$ & 07 & 31,4 \\
\hline $40-49$ & 11 & 8,5 \\
\hline 50 ou mais & 3 & $\mathbf{1 0 0 , 0}$ \\
\hline Total & $\mathbf{3 5}$ &
\end{tabular}

A média de anos estudados pelas mulheres deste estudo é de 3,17 anos, sendo que, $8(22,9 \%)$ das mulheres nunca frequentaram a escola. Também, encontrou-se $16(45,7 \%)$ que tiveram entre um a quatro anos de estudo, o que as caracteriza como analfabetas funcionais, segundo a classificação considerada pelo Ministério da Educação, que considera como analfabetismo funcional o indicador do nível de escolaridade para um a 
quatro anos de instrução. Ainda, conforme a Tabela 2, apenas $3(8,5 \%)$ delas concluíram o Ensino Fundamental; e um (2,8\%), o Ensino Médio completo.

Vários estudos no Brasil também encontraram, em grupos de catadores, o quadro de baixa escolaridade, com maioria de analfabetos, tendo no máximo concluído o ensino fundamental (SANTOS; SILVA; 2011; PORTO et al., 2004; SANTOS et al., 2013).

$\mathrm{O}$ quadro de baixa escolaridade, encontrado entre as mulheres da Comunidade Mangabeira, reflete a falta de acesso à educação presente em todo estado de Alagoas. Dados da PNAD (2008) sobre o perfil de escolaridade da população economicamente ativa, mostraram que $24 \%$ dessa população não possuíam instrução alguma e que $45 \%$, tinham o primeiro grau completo ou incompleto. Apenas 4\% dessa população tinham 14 ou mais anos de estudo, portanto passíveis de atender aos requisitos exigidos pelo competitivo mercado de trabalho (IBGE, 2010).

Tabela 2- Distribuição das mulheres moradoras da Comunidade Mangabeira, segundo a escolaridade, Arapiraca, 2014

\begin{tabular}{l|l|l}
\hline \multirow{2}{*}{ Escolaridade em anos } & Mulheres \\
\cline { 2 - 3 } & $\mathbf{N}$ & $\mathbf{\%}$ \\
\hline Nenhum estudo & 8 & 22,9 \\
\hline 1 a 2 anos & 9 & 25,7 \\
\hline 3 a 4 anos & 7 & 20 \\
\hline 5 a 6 anos & 8 & 22,9 \\
\hline 7 ou mais & 3 & 8,5 \\
\hline Total & $\mathbf{3 5}$ & $\mathbf{1 0 0}$ \\
\hline
\end{tabular}

Mesmo com baixa escolaridade, a oportunidade de estudar significa para essas mulheres uma possibilidade de melhoria de vida, mas difícil de ser alcançada, devido às dificuldades que as acompanham desde a infância e distanciam-nas da volta à escola na idade adulta. 
DSC. 1 Parei de estudar, mas quero voltar

Eu parei de estudar porque na época, onde os meus pais moravam não existia colégio, não tinha oportunidade e eu não entendia nada, eu achava que eu não aprendia. Depois eu casei e não dá para trabalhar, estudar e tomar conta de casa. Eu já voltei tantas vezes a estudar, mas quando engravido, eu tenho vergonha de ir para escola. Agora, eu queria voltar a estudar, penso direto, o problema é que muito cansativo para a pessoa chegar do serviço e estudar à noite. Disseram que vai ter um prójovem, só que para os mais velhos. Estou esperando e até agora não botaram.

Entre as dificuldades de conseguir estudar estão à falta de escolas próximas ao local de moradia, a sobrecarga de trabalho junto às responsabilidades de manutenção do lar e cuidados com filhos. Essas mulheres também se consideram incapazes de aprender, o que dificulta ainda mais a sua permanência na escola. O estudo de Mani et al. (2013), realizado nos EUA, sobre a função cognitiva de pessoas vivenciando a escassez de recursos financeiros, afirma que a pobreza reduz a capacidade cognitiva e esclarece que isso ocorre porque as preocupações relacionadas à pobreza, consomem todos os recurso mentais, deixando assim menos recurso para outras tarefas. Portanto, essa incapacidade de aprender relatada pelas mulheres do nosso estudo é comportamental, e dentro deste contexto, consideram-se menos capazes, de forma a perpetuar ainda mais a pobreza, segundo afirma essa mesma autora.

O sentimento de vergonha relacionado ao retorno à escola, após terem filhos, é outra condição referida pelo grupo como empecilho para a retomada dos estudos. Mesmo assim, elas mantêm a esperança da volta aos estudos em turmas escolares específicas de educação para adultos, na própria comunidade.

Essa mulher percebe e reflete sobre todas as dificuldades que encontra para estudar, ao mesmo tempo expressa um "querer" constante de voltar a estudar mesmo reconhecendo todos os empecilhos. Mas enquanto ela não se vê em condições de estudar, reconhece nos filhos essa possibilidade. 
DSC. 2 Queria dar o estudo que eu não tive aos meus filhos

Os meus filhos mais velhos eu botei para estudar tudinho, só que só se ligavam no trabalho, como eu vivia sozinha, carreguei eles para lixo logo cedo. Os outros que estão casados não quiseram estudar, sabem ler mais não é lá essas coisas toda, não aprenderam foi nada na vida. Eu queria dar o estudo, que eu não tive, aos meus filhos, é o recurso que eu posso dar a eles, por isso sempre digo a eles: estudem, não queiram ficar como sua mãe. Se eu tivesse tido a chance que eles tiveram e os mais novos têm hoje, talvez eu não vivesse na vida que eu tenho.

Assim, a escola representa o sentimento de esperança em poder oferecer aos seus filhos uma vida melhor. E elas "querem" que os filhos estudem, pois reconhecem na educação a única possibilidade de chance para mudança de vida. Porém os problemas e as dificuldades, em mantê-los na escola, assemelham-se aos de suas mães, inclusive com a repetição das mesmas condições de trabalho, determinadas pela início do trabalho no "lixão", ainda em idade escolar.

Esse processo de interação social demostra que essas mães associam a oportunidade de estudo dos seus filhos, como um esforço pessoal, feito por elas. Porém esse esforço, realizado pela mãe, para manter seus filhos na escola só poderá ter sentido mediante a ação de estudar, que é realizada por eles. Mas, os filhos enfrentam as mesmas dificuldades, pelas quais suas mães passaram, para conseguir estudar. Além disso, na dinâmica das interações sociais, as ações vão sendo definidas, nem sempre o estudo tem o mesmo significado para mães e filhos, cada um, em seu momento de vida. Diante de toda essa problemática, alguns autores ainda explicam que a pobreza na infância pode prejudicar o desenvolvimento do cérebro e assim ter impactos negativos sobre a capacidade cognitiva de adultos (EVANS; SCHANBERG; 2009; MANI et al., 2013), e as condições de tragédia de pais e filhos podem ser reproduzidas, nesse contexto de poucas oportunidades.

O DSC. 3 trata da condição marital, sendo importante ressaltar que $82,8 \%$ das mulheres entrevistadas afirmaram conviver com os companheiros, nos seus lares, e assim compartilharem as responsabilidades, 
com alguns maridos, chegando a contribuir com uma baixa remuneração, vinda do trabalho. Mesmo assim, essas mulheres continuam a ter a maior carga de atribuições, pois, além do trabalho, ainda assumem os cuidados com a casa e com os filhos.

DSC. 3 Passei muita vergonha, necessidade e violência com meus filhos até me separar do marido

Eu me casei bem novinha e nunca tive sossego, todo ano era um filho, eu tinha um no princípio do ano e tinha outro no final do ano. Mas o pai não dá nada para os filhos, sempre fui eu. Já passei muita vergonha, porque ele vivia me esculhambando e brigando. Passei muita necessidade, ele fazia a feira e botava na telha para eu não dar de comer aos meus filhos, só pedindo a Deus. Eu nem digo que tem pai, só arruma mixaria e vai tomar de cachaça e quando não arruma, para cachaça não falta quem não dê. Ele ainda gasta o dinheiro com as outras mulheres. Teve uma vez. que ele bebeu muito e chegou em casa bêbado, na hora da dormida ele se virou e meteu o joelho na minha barriga, eu grávida, abortei. Eu cansei de tomar faca, facão dele, a gente se pegava no tapa e os meninos vinham em cima para apartar, cheguei até a dar parte dele aqui na delegacia e o delegado disse se ele começasse, ele ia ser preso, mas mesmo assim ele continuava. E nesse tempo não tinha a lei da Maria da Penha como tem agora. Eu aguentei até as crianças crescerem, quando cresceram me separei, não ia trabalhar para mim, ele e os filhos. Estou mais sossegada depois que me separei dele. O pai dessa outra mataram e eu fiquei um tempo só, aí depois foi que eu arrumei outro, outro inferno. Esse de agora, eu fui morar com ele, e ele está me ajudando agora e não trabalho, fico só em casa. Eu estou com ele, só quem sabe se vai dar certo é Deus. Ele cuida, dá carinho a minhas filhas, brinca com elas, fica olhando elas para eu cuidar das coisas. E minhas filhas diz que o pai é o que cria.

Frente ao exposto, as relações conjugais enfrentam várias fragilidades, inerentes ao contexto da vida na comunidade, como o alcoolismo e a violência, uma vez que, quando se voltam para os lares, geram sofrimento que são estendidos às crianças que presenciam ou sofrem agressões, 
chegando à violência física. Estudo de Porto, et al. (2004), ao entrevistar um grupo de catadores, menciona que $79,8 \%$ apontam que seus colegas catadores fazem uso frequente de bebida alcoólica, e apenas 31,6\% assumiram que são eles que consomem esse tipo de bebida de forma constante.

Apreende-se que na pobreza, as questões que envolvem a liberdade de decisão da mulher, acerca de suas relações conjugais, parecem apresentar-se de forma mais complexa. Algumas mulheres permanecem, por muito tempo, em relações conjugais, em que são desrespeitadas e violentadas. Assim, com uniões tão sofridas, conseguir a separação significa uma vitória e uma possibilidade de recomeço. A manutenção dessas uniões conjugais parecem ter sua ocorrência relacionada à preservação da presença paterna durante o crescimento dos filhos; dentro da família. Ter o pai presente, quando os filhos ainda são pequenos, tem um significado construído socialmente, de que, só uma família completa, com pai, mãe e filhos, pode conduzir de forma adequada o crescimento dos filhos, junto a isso, as mulheres se percebem socialmente mais frágeis, diante da responsabilidade de criar seus filhos sozinhas, mesmo com a presença do homem.

Como esses significados vão se reconfigurando com o crescimento dos filhos, grande parte das mulheres, deste estudo, não convive com o mesmo companheiro. Observa-se que 53\% delas, têm filhos de mais de uma relação conjugal. Cada nova união conjugal representa uma esperança de encontrar um pai para seus filhos, e assim ter sua família completa, dentro da definição de família percebida pelo seu meio social.

\subsubsection{Descrição da renda familiar}

Como a renda da maioria das famílias tem como base a venda de material reciclado, o lucro dessa atividade está condicionado ao que se produz, de acordo com o que se encontra no lixão, por isso há uma dificuldade em determiná-la, já que é bem variável. Além disso, a catação está condicionada a vários fatores, como a diversidade do material encontrado no lixo, à quantidade de catadores no lixão no momento da 
coleta, à produtividade de cada catador por dia, ao tempo destinado à catação e até ao modo como o catador vai vender seu produto. Santos e Silva (2011) confirmam os achados deste estudo, ao encontrar o mesmo perfil de renda, em outro grupo de catadores. Com famílias obtendo rendimentos variados, recebendo conforme o que produz em seu dia de trabalho, com ganhos financeiros sempre inferiores a um salário-mínimo. A variação de renda do trabalho de catador é justificada pelo tempo dedicado ao trabalho, à qualificação na atividade (escolha de materiais e rapidez na catação) e ao papel exercido quando da existência de pequenos grupos de trabalho (PORTO et al., 2004).

Mesmo assim, essas mulheres estimam uma média mensal de rendimentos que pôde ser organizada tomando como base o sálario-mínimo vigente. Assim, no grupo estudado, 45,7 \% das famílias sobrevivem com menos de um salário-mínimo mensal. As famílias que ganham mais de um salário-mínimo (54,3\%) têm essa renda maior advinda de aposentadorias ou benefícios. Nesse pequeno grupo estudado, nenhuma família possui renda acima de dois salários-mínimos (Tabela 3).

Tabela 3- Distribuição das mulheres moradoras da Comunidade Mangabeira, segundo renda familiar estimada, em salário-mínimo, Arapiraca, 2014

\begin{tabular}{l|l|l}
\hline \multirow{2}{*}{ Renda } & Mulheres \\
\cline { 2 - 3 } & $\mathbf{N}$ & $\mathbf{\%}$ \\
\hline Menos de 1 salário & $\mathbf{1 6}$ & $\mathbf{4 5 , 7}$ \\
\hline 1 a 2 salários & $\mathbf{1 9}$ & $\mathbf{5 4 , 3}$ \\
\hline TOTAL & $\mathbf{3 5}$ & $\mathbf{1 0 0}$ \\
\hline
\end{tabular}

NOTA: Salário-mínimo de 678,00 reais

Mais da metade das famílias (60\%), dessa comunidade, estão cadastradas e recebem a Bolsa Família, portanto $40 \%$ das famílias apresentam os critérios de elegibilidade para receber esse recurso e não recebem, isso por não conseguirem cumprir as condicionalidades, que são compromissos que devem ser cumpridos pela família para manter-se recebendo esse incentivo, dentre estes a falta de acompanhamento de cartão 
de vacina e absentismo escolar de seus filhos, perda de documentos, que impossibilitam os recadastramentos, entre outros. Assim, muitos dos que mais precisam dos programas de incentivo governamental continuam a ser excluídos desse beneficio, necessário, para possibilitar melhoria na qualidade de vida das famílias (SANTOS et al.,2013)

Assim, a Bolsa Família é uma importante fonte de recursos na comunidade e, muitas vezes, chega a ser a única fonte de renda de algumas famílias, durante os períodos de absentismo ao trabalho, no entanto, ainda é insuficiente para o atendimento pleno das necessidades básicas..

DSC. 4 Só o Bolsa Família não dá para tudo que meus filhos precisam

Hoje, graças a Deus, para a vista do que já passei, eu estou muito bem, porque chegou o Bolsa Família. Primeiro chegou o PETI, aí eles começaram entrar no PET $T^{l}$, estudando, aí pronto... já foi mudando as coisas, já fui comprando roupa para eles, umas coisinhas e tudo. Hoje em dia está melhor um pouco, mas, só o Bolsa Família não dá para tudo que eles precisam. Eu também não estou podendo trabalhar, por estar doente, estou vivendo agora só com a Bolsa Família.

É possível perceber no DSC 4 que as mulheres valorizam essa renda e atribuem a esse recurso uma melhoria de vida, vivenciada por meio através do acesso a outros bens de consumo que antes não tinham. Ao mesmo tempo, têm consciência de que não é suficiente para o sustento de sua família. Ou seja, após passado a expectativa do início de recebimento desse rendimento, ele logo é percebido como insuficiente para a melhoria de vida que esperavam ter ao recebê-lo.

Estudos mostram que a decisão sobre alocação desse recurso pelas famílias, era predominantemente feminina (mais de $90 \%$ do sexo feminino). E comprovam que os gastos foram utilizados principalmente em educação, alimentação e vestuário (IBASE, 2008, MAGALHÃES et al., 2013). Ao se

\footnotetext{
${ }^{1}$ Programa de Erradicação do Trabalho Infantil (Peti) articula um conjunto de ações para retirar crianças e adolescentes com idade inferior a 16 anos da prática do trabalho precoce.
} 
perceberem com uma renda insuficiente só demonstram as múltiplas necessidades familiares (BURLANDY, 2007).

Em estudo realizado com famílias do PBF, verificou-se que a aquisição de bens ou alimentos eram considerada "luxo" no cotidiano dessas famílias, marcava uma possibilidade de ruptura com as condições extremamente adversas a que estavam submetidas (IBASE, 2008). Os indivíduos e as famílias em situação de vulnerabilidade social não só possuem um baixo nível de renda, como é o caso das famílias cadastradas no PBF, mas também uma série de indicadores desfavoráveis como: baixa escolaridade e qualificação profissional; limitado acesso a informações; maior dificuldade de acesso a serviços básicos; piores condições de habitação e saneamento; e maiores gastos proporcionais com alimentação e saúde, dentre outros, somando um conjunto de fatores que se interrelacionam e reforçam a desigualdade existente na sociedade (SILVA, 2007; CNDSS, 2008). Ou seja, tais famílias possuem múltiplas necessidades e poderiam se beneficiar de um conjunto de outras abordagens e ações sociais.

\subsubsection{Características das relações de trabalho}

Os catadores tiveram sua profissão regulamentada em 2002, sob o número 5192, são registrados na $\mathrm{CBO}$ - Classificação Brasileira de Ocupações. O reconhecimento da profissão de catador de material reciclável representou um importante passo na busca por reconhecimento de seus direitos. Porém foram poucos os avanços em relação à formalização das relações de trabalho com predomínio da informalidade nas relações de trabalho (MEDEIROS; MACEDO, 2006).

A maioria das mulheres deste estudo, desenvolvem atividades na reciclagem (51,5\%). Mesmo as que estão afastadas do trabalho conhecem bem o dia a dia dessa atividade, por já terem trabalhado, ou por terem seus familiares trabalhando nesse contexto. Para alguns autores, a baixa escolaridade é um fator que direciona para a exclusão do mercado formal de trabalho (SILVA; GONÇALVES, 2009; MAGERA, 2003). Além dessa constatação, outro estudo aponta que a baixa escolaridade também está 
associada à autoimagem que os catadores fazem de sua profisssão e posição social, o que faz sentindo quando se olha para os dados deste estudo. Muitos catadores associam a falta de estudos à condição de ter que viver do trabalho de catação, o que para muitos representa humilhação e vergonha, demostrando, assim, o preconceito e o descrédito que os próprios catadores têm em relação à profissão que exercem (MEDEIROS; MACEDO; 2006).

Portanto, a falta de oportunidade no mercado formal de trabalho é apontada em outro estudo como o motivo mais marcante para a busca de uma ocupação no "lixo", entretanto, a necessidade de "ajudar em casa", complementando a renda dos familiares, foi um motivo que mereceu destaque entre aqueles que começaram a trabalhar ainda crianças (PORTO et al., 2004). Mani, et al.(2013), em seu estudo, aponta que a redução da capacidade cognitiva, inerente às preocupações com a pobreza, tem relação direta com o fato de serem trabalhadores menos produtivos.

O estudo de Medeiros e Macedo (2006) apresenta as difíceis e precárias condições em que os catadores desenvolvem seu trabalho. Os problemas existentes nessa atividade vão desde os riscos à saúde, o desamparo de garantias trabalhistas, principalmente em condições de acidentes do trabalho, doenças, aposentadoria, falta do décimo terceiro salário, ausência de seguro desemprego e baixa remuneração, mesma situação encontrada nas relações de trabalho no lixão da Mangabeira.

Dessa forma, a falta de oportunidade de trabalho é mostrada no DSC. 5.

DSC. 5 Trabalho no lixão por não ter outra opção de sobrevivência

Trabalho no lixão porque preciso, porque quem é pobre não tem outro emprego para trabalhar, tem que trabalhar lá. Não tem outra opção, vai fazer o que, tem que gostar de trabalhar no reciclado, porque trabalhar em casa de família eu não gosto não. Esse negócio de empregado e patrão, de estarem mandando em mim. Ninguém quer ser mandado por ninguém, por isso que aqui, ninguém trabalha fichado não, aqui todo mundo trabalha por sua conta. Mas ninguém gosta porque é um serviço nojento, em tempo de chuva é um fedor, fica um mau cheiro dos bichos mortos e eu fico com muita dor de cabeça, quando chego em casa 
não dá nem vontade de comer. Ainda assim, é melhor do que está parado e dá para sobreviver. Se trabalhar direitinho, não dá essas coisas todas, mas dá. Tem que dar graças a Deus, de ter ele para sobreviver. O trabalho no reciclado é forçado, não se pode perder uma coleta, porque se perder não enche, quando um caminhão chega, tem que ir cata lá. Trabalha o dia todinho e pode vender os materiais no próprio lixão, se não quiser, traz para casa para vendê. Tem gente que mora aqui, que compra para separar aqui mesmo e vender às pessoas de fora.

A atividade na reciclagem é interpretada por essas mulheres como "nojenta" e "forçada". Realizam esse trabalho, porque são pobres e por não haver outra opção para sobrevivência. Em outras pesquisas também se encontra essa relação de trabalhar no lixo por falta de opção, e como único meio de sobrevivência encontrado, sendo essa uma característica comum a esses grupos sociais, conforme publicações (SANTOS; SILVA; 2011; ZABETI, 2006; VELLOSO; et al.; 1998).

O nojo é decorrente do forte odor advindo do lixo em decomposição que gera sentimentos de mal-estar, e todos acabam por terem a obrigação de vivenciar tal situação. A pesquisa de Santos e Silva (2011) também encontrou o incômodo do mau cheiro, que chega a afetar a saúde, enfocando que os depoimentos dos catadores trazem ainda a ideia de que há uma falta de identidade com o trabalho e sugerem uma autoculpabilização pela exclusão social.

O trabalho é considerado forçado, porque exige resistência e força física. Outras pesquisas vão além do cheiro forte e trabalho forçado, como o que se encontra entre as catadoras do lixão da Mangabeira, pois destacam como problemas em seu bairro e ambiente de trabalho, as questões como a sujeira, a poeira, o cheiro forte e o risco de contaminações variadas, tanto pela presença de moscas, mosquitos e ratos, quanto pelo gás oriundo do lixo. Sobre esse assunto, Miura (2004) comenta que os catadores não parecem preocupados com os prejuízos provocados à saúde pelo trabalho, estes são suplantados pelo fato dessa atividade garantir sua subsistência e promover sua inserção social e profissional. Segundo a autora, as dores nas pernas, a intoxicação pelo lixo, os cortes, os arranhões, tudo isso pode ser 
curado, o que é mais dolorido do que tudo isso é a fome. Porto et al,. (2004) ressaltam que os catadores percebem o lixo como fonte de sobrevivência, a saúde como capacidade para o trabalho e, portanto, tendem a negar a relação direta entre o trabalho e problemas de saúde.

Apesar de essa atividade ter, para algumas mulheres, um significado negativo, é através dela que é possível garantir a sua sobrevivência e de sua família e ainda permitir uma flexibilidade de horário que elas não teriam em outra opção de emprego, como, por exemplo, o trabalho de empregada doméstica. O estudo de Dall'agnol e Fernandes (2007) mostra que mesmo trabalhando no lixo, muitos estão satisfeitos com o trabalho, muito decorrente do fato de os entrevistados posicionarem o lixo como meio de sobrevivência. Além disso, o trabalho na reciclagem traduz a esse grupo um sentimento de autonomia, pois, apesar de tudo, não existe "patrão". Outro artigo apresenta uma característica também encontrada neste estudo, que a questão da autonomia no trabalho, em que um motorista se torna catador ao ficar desempregado e mesmo tendo uma nova possibilidade de retorno ao trabalho, opta por continuar na reciclagem, pois não quer ter que se submeter ao patrão, apesar do desagrado da própria família, pela decisão de sobreviver de restos da sociedade (VELOSO, 2005).

Esse sentimento de autonomia também está relacionado à escolha na forma de conduzir os ganhos pela atividade de reciclagem, pois é o catador que organiza o seu horário de trabalho e a forma de vender o material coletado, e pode optar se realiza a venda direta a pessoas de fora da comunidade, os chamados atravessadores, ou vendem a pessoas que moram na própria comunidade, que vivem da compra e da venda dos materiais recicláveis, pois negociam em grandes quantidades. Porto et al., (2004) também apresentou a mesma informação encontrada aqui, em que a maioria dos entrevistados afirmou que sua preferência é continuar mantendo sua atual situação de trabalho, decorre de uma maior flexibilidade na escolha do seu tempo para o trabalho.

No entanto, a sobrevivência com trabalho na catação de reciclados diretamente no lixão vem sendo afetada, na Comunidade Mangabeira, por conta da desativação dos lixões de cidades vizinhas, que passaram a ter 
aterros sanitários fechados. Assim, vários catadores continuavam a chegar para a catação de reciclado no lixão de Arapiraca, o que tem causado o que as mulheres descrevem como "Muita gente para pouco lixo dificultando a sobrevivência” (DSC. 6).

DSC. 6 Muita gente para pouco lixo dificulta a sobrevivência

Antigamente era bom trabalhar no lixão, porque tinha pouca gente, hoje é muita gente, vem gente até de fora trabalhar aqui. Foi muita gente embora e vieram mais dos outros interiores que os lixões fecharam, como Maceió e Palmeira. Aqui já foi bom na verdade. Era um lugar que dava bastante dinheiro para sobreviver e agora está cada vez pior, uma coleta só não dá para meio mundo de gente trabalhar. Termina ficando um monte de gente para pouco lixo. Tem que procurar outros meio para sobreviver. A gente que trabalha no lixo ganha menos de um salário, por isso é melhor trabalhar fixo, porque tem dia que não dá para arrumá nada lá. Nós até fomos trabalhar no lixão de outra cidade porque não tem tanta gente (para dividir o reciclado). Mesmo assim, quando o lixo sair daí, vai ser ruim, pois muitas pessoas vão ficar sem ter serviço. Para muita gente que sobrevive dali, vai sofrer. Agora estou trabalhando na reciclagem, é quase um tipo de uma firma, para separar o material, cada cor tem o seu canto. Se eu trabalhasse para mim era bom, ganho 25 reais o dia,se eu for trabalhar, mas o homem é tão chato e ignorante, que a pessoa só trabalha porque precisa. Lá é melhor e ao mesmo tempo não é, tem a hora certa de chegar, de sair e se você precisar resolver alguma coisa na rua, você já falta e já é descontado.

Além disso, ainda convivem com o medo de também ter o lixão fechado e, assim, precisarem encontrar outro trabalho, sem qualquer preparo ou formação. O trabalho em galpões de reciclagem é outra opção que tem surgido na comunidade, porém esses galpões não oferecem trabalho assalariado, e sim um trabalho por produção com pagamento por diária.

Algumas mulheres sentem-se "divididas" entre o trabalho direto no "lixão" e nos galpões. Isso porque o trabalho no lixão vem acompanhado do odor fétido emitido pelo lixo, além da questão do desgaste físico. Por outro 
lado, nos galpões, elas sentem a perda de sua autonomia, por terem a figura de um patrão em seu ordenamento. O estudo de Porto et al., (2004) mostra uma preferência das mulheres pelo trabalho em galpões, isso sendo justificado por menor exigência de esforço físico nesses locais.

Esses sentimentos ambíguos são expressos no DSC. 7, em que as mulheres percebem uma linha divisória entre cuidar dos filhos e continuar trabalhando.

DSC. 7 Sem trabalho por conta da gravidez, dos filhos e do marido

Eu trabalhava com tudo, só não catei lá embaixo, mas separei e classifiquei para poder imprensar. Eu parei, porque o rapaz que eu trabalhava diminuiu, tinha muita mulher, aí ele tirou umas 4 e eu fui no meio. Não tem nada (de trabalho) para mim fazer agora. Também não estou trabalhando por conta dessa gravidez, não ajudo mais meu marido no trabalho por causa dos meus filhos. No primeiro filho eu trabalhava até grávida, agora só quem trabalha é meu marido. Eu não tenho família aqui para ficar com eles, por isso, eu tenho que está em casa para tomar conta delas, e não deixar elas no meio da rua. Agora meu serviço é só dentro de casa. Mas também meu marido não deixa eu ir, por conta da gravidez, ele não quer que eu trabalhe. Ele disse que eи não ia mais trabalhar, porque trabalho é responsabilidade dele. Às vezes, eu acho bom, mas às vezes eu acho muito machismo de homem não querer que mulher trabalhe. E agora o meus filhos começaram a estudar e eu não estou tendo ocupação com eles, então isso não me proibiria de trabalhar, porque agora as escolas são em tempo integral. Eu tenho muita inveja do marido e da mulher que vivem ajudando um ao outro no trabalho.

Alguns companheiros consideram a atividade no trabalho na reciclagem de lixo de suas mulheres não compatível com a gravidez, puerpério e cuidados com a casa e com os filhos. Muitas vezes, a mulher percebe esse afastamento do trabalho, para cuidar da casa e dos filhos, como necessário, para garantir os cuidados com o grupo familiar. Mas, ao mesmo tempo, esse processo gera nessas mulheres sentimento ambíguo entre querer voltar ao trabalho e continuar a cuidar somente de seu lar. Nesse processo, 
elas responsabilizam o "machismo" de seus companheiros como um dos empecilhos para seu retorno ao trabalho no reciclado.

Como já foi discutido anteriormente, para esse grupo de mulheres, o trabalho tem seu significado relacionado à sobrevivência, que carrega consigo uma carga de preconceito social, além de ser interpretada como um trabalho nojento e forçado. No entanto, poder se afastar dessa atividade para cuidar dos filhos e de casa, só é possível quando o sustento da família é percebido pelo casal como de responsabilidade do companheiro, e por ele assumido. Á medida que os filhos crescem algumas mulheres se sentem divididas entre retornar ao trabalho no lixo e suas dificuldades ou continuar em casa, na dependência financeira exclusiva de seu companheiro. Essas mulheres interpretam a relação de sua contribuição no trabalho junto ao companheiro como uma forma de melhorar sua relação conjugal, e assim estabelecer uma relação de companheirismo.

Estudo de Capucha (1998) encontrou a mesma relação entre o desemprego e a dificuldade de trabalhar em um grupo de mulheres com alta taxa de natalidade. Relacionando, também essa problemática, a um quadro geral de grande escassez de oportunidades de inserção profissional, a baixa qualificação e acomodação a círculo de pobreza instalada.

Como mostra o DSC. 8, há algumas mulheres que estão "Prontas para trabalhar em qualquer atividade para sobreviver"

DSC. 8 Prontas para trabalhar em qualquer atividade para sobreviver

Eu sempre trabalhei em casa de familia. É faxina, lavar roupa, mas na maioria das vezes eu faço tudo dentro de casa e vou levando minha vida. Também já cuidei de uma pessoa paralítica até chegar o último dia de vida dela, trabalhei dois anos numa granja que fiquei com um problema no dedo, pois machuquei naquela máquina de pelar galinha, ela estava dando choque, arrancou minha unha com tudo, mesmo com o dedo ferido eu ia trabalhar. Logo quando eu cheguei, fui logo trabalhar no fumo para criar eles, aí depois deixei a firma de fumo, porque não aguentei mais e fui trabalhar no lixo e até hoje. Toda minha vida eu 
trabalhei sempre precisando. Sei que estou sempre pronta pra ganhar qualquer mixaria, com fé em Deus eu me viro.

A baixa formação educacional faz com que as oportunidades de trabalho sejam poucas e relacionadas aos cuidados domésticos, à agricultura da região e ao trabalho na catação do reciclado. Para essas mulheres, o trabalho significa a garantia de seu sustento e de seus filhos e está sempre presente em sua vida, junto com a fé em Deus. Várias outras pesquisas relacionam a baixa escolaridade com a dificuldade de conseguir um trabalho formal (PORTO et al., 2004; VELOSO, 2005; SANTOS; SILVA; 2011; ZABETI, 2006; VELLOSO et al., 1998). Por isso Porto et al. (2004) identificaram em seu estudo algumas ocupações desempenhadas por catadoras, que foram sendo deixadas para trás por elas, para ingressarem no trabalho com o lixo, tais como cozinheiras e costureiras. Essas informações condizem com a mesma realidade encontrada entre as catadoras da Comunidade Mangabeira, como vista no DSC. 8.

Somente nos últimos quatro anos, as mulheres da comunidade passaram a contar com o serviço de uma creche na própria comunidade. Mesmo contando com este serviço, que tem uma avaliação positiva na comunidade, muitas ainda vivenciam o medo do Conselho Tutelar em “tomar" seus filhos, se eles as acompanharem nas atividades no lixão. Isso porque, antes da instalação da creche na comunidade, era uma prática comum entre as mulheres que trabalhavam no lixão levarem seus filhos pequenos para o trabalho (DSC. 9) .

DSC. 9 Filhos menores no lixão e o medo da apreensão do Conselho Tutelar

Antigamente meus filhos iam para o lixo cedo, naquela época não tinha escola aqui e eles catavam reciclagem e já me ajudavam. O povo brigava comigo, mas é melhor andar comigo nos braços do que ficar em casa sozinhos, aí eu levava. A minha filha de vez em quando se inventava de me ajudar, mas eu nunca quis não, nunca obriguei, ela ia de livre $e$ espontânea vontade, ela queria me ajudar e ia. Agora lá, não querem mais criança no lixo, por isso ninguém leva mais, com medo, porque vai não 
vai, chega o pessoal do Conselho Tutelar lá embaixo e se um dia pegarem minhas filha e levar, aí eu ia ficar doida e ia logo ser presa. Não quero meus filhos lá, nem para me levar um gole d'agua, para sofrer só basta eu mesmo, eu quero eles da escola para casa. O que eu quero é que estudem ou faça uma comida, limpe um fogão, essas coisas e fazendo isso para mim já tá ótimo.

Algumas dessas mulheres percebem que o lixão não é local adequado para os filhos, mas este trabalho no lixão é uma realidade materna diária, por isso é bem próxima também para as crianças, mesmo que não frequentem regularmente o local.

Muitos estudos descrevem ter encontrado relatos da presença de crianças no trabalho nos lixões, com catadores referindo trabalhar nessa ocupação desde a infância. Alguns pesquisadores registraram a presença de crianças menores de 10 anos trabalhando no lixão (SANTOS; SILVA; 2011; VELOSO, 2005; SANTOS et al., 2013, PORTO et al., 2004). Por isso há de se perceber a importância do trabalho do Conselho Tutelar que vem sendo feito na comunidade da Mangabeira, ao evitar uma prática que era comum,

porém danosa para as crianças. É complexo compreender e justificar a presença de crianças, com aval de seus pais, em um lugar tão insalubre, mas Mani et al. (2013), em seu estudo, aborda que os pais em uma vivência de pobreza apresentam um comportamento contraproducente, que é traduzido como pais menos atentos no cuidados aos seus filhos. Com essa relação é possível perceber como o contexto de pobreza influencia na dicotomia dos cuidados com os filhos.

\subsubsection{Percepção do local de moradia}

O local de moradia é um aspecto relevante para se compreender o contexto de vida no qual estão inseridas essas mulheres. Com base nas falas sobre o local de moradia, é possível perceber as singularidades das relações estabelecidas nesse ambiente social.

A descrição do local de moradia é realizada mostrando um dualismo entre aspectos positivos e negativos de se residir na Comunidade 
Mangabeira. Mas, as falas negativas são mais contundentes e apontam o medo da violência, o preconceito que pessoas de fora da comunidade têm com os moradores do lixão, vinculados a um querer residir em outro lugar, que é percebido como uma possibilidade de mudança de vida. No entanto, a concretização de ter uma vida melhor, e poder morar fora dessa comunidade, nem sempre é possível, mesmo que sejam oferecidas possibilidade de residir em outro lugar, como poder morar em conjuntos habitacionais construídos pelo governo. Isso porque existe uma relação de proximidade geográfica, conveniência e interação comunitária direta entre os moradores da Comunidade Mangabeira e o trabalho no lixo.

\section{DSC. 10 Gosto de morar na Mangabeira}

Tudo mudou na minha vida, graças a Deus, depois que eu cheguei aqui. Eu gosto de morar na Mangabeira, gosto de tudo, do trabalho, do lugar. Não me incomodo com a vida de ninguém, nem quero que se incomodem com a minha. É bom porque aqui tem ajuda dos amigos do bem $^{2}$ e de vez em quando me dão alguma coisa. Aqui é melhor porque tem onde se trabalhar e as mães que trabalham têm a creche para colocar os meninos e lá elas tomam conta e as mães não se preocupam com comida, nem remédio, se algum adoecer elas levam para o hospital e já chega com a receita. Aqui, se tiver dinheiro a gente compra, senão a gente pede emprestado e quanto receber do serviço paga. Por isso prefiro ficar aqui, enquanto o lixo não fechar eu prefiro ficar por aqui mesmo.

Ao vivenciarem, no presente, pequenas melhorias na qualidade de vida, como o recente acesso à creche e ao Ensino Básico para crianças, oferecidos pelas escolas locais, assim como as relações de ajuda e solidariedade, percebem condições melhores, quando comparam o seu momento atual com o passado de sofrimento e privação. Tudo isso leva algumas mulheres a considerarem a sua vida, em seu local de moradia, como um bom local para se viver.

\footnotetext{
${ }^{2}$ ONG paulista que envia mensalmente uma cesta básica para cada família moradora da comunidade Mangabeira.
} 
Mesmo quando algumas mulheres retratam as qualidades positivas de se morar na Mangabeira, por ter uma rede de interações que facilitam a sua vivência, elas também percebem que pelo menos em algumas situações elas precisam se proteger dizendo "Não me incomodo com a vida de ninguém, nem quero que se incomodem com a minha", que, simbolicamente, representa a forma encontrada para se distanciar de alguns problemas que não são possíveis de serem resolvidos, mas precisam ser mediados.

Como as interações simbólicas ocorrem de forma dinâmica, a interpretação do contexto também é percebida de forma diferente, em um processo constante, de definição e redefinições, até chegar ao significado da Comunidade Mangabeira para cada mulher. Assim, muitas referem aspectos positivos de residir nessa comunidade, já outras têm uma percepção negativa sobre seu lugar de moradia, como pode ser percebido nos DSC abaixo.

DSC. 11 Não gosto de morar na Mangabeira, porque é longe e violento

Para quem mora aqui tudo é mais difícil, tudo é mais longe, eu prefiro morar na cidade que é melhor por que fica mais perto de tudo. Eu vim morar aqui por falta de opção, porque tinha pouco dinheiro e não tinha condição de comprar minha casa em um lugar melhor. E a comunidade é um pouco violenta, mas cada um tem a sua vida, o problema é que por nada o povo tá matando e aqui dentro rola muita droga e eu vejo muita criança se envolvendo com esse negócio. Já senti muito medo, e até hoje eu tenho medo, eu fiquei com trauma dos tiros que mataram meu marido, tinha noite que eu nem conseguia dormir direito, pode crer, ficava imaginando qualquer hora dessas me matarem.

Para algumas mulheres, morar na comunidade não foi uma escolha, mas sim a única opção, diante da falta de recursos para poder ter uma casa em outro lugar. O convívio com a violência, em seu local de moradia, gera sentimentos como o medo e a insegurança. A exclusão social em que vivem essas mulheres e suas famílias nessa comunidade carente parece ter reflexo direto em altos índices de violência, com o tráfico de drogas atuante. A 
estratégia de defesa da população que vive nesse contexto de violência é a resignação, pois afirmam "que cada um tem a sua vida", na tentativa de desvalorizar a influência negativa que sofrem ao morar nessa comunidade. Essa atitude parece favorecer uma tentativa de isolamento dos aspectos negativos de estar inserido nesse contexto de vida, por isso, agir de forma individualizada passa a ser uma estratégia de defesa encontrada por algumas mulheres para continuar a manter-se nesse ambiente. Porto et al. (2004) identificou em sua pesquisa com catadores que residem no entorno do lixão, que mais da metade $(51,4 \%)$ dos entrevistados gostariam de mudar para outra localidade.

Não por acaso, em diversas partes do mundo, verifica-se que aqueles que dispõem de pior situação financeira são também os que têm maiores dificuldades de acesso aos serviços e às políticas públicas, habitações adequadas, água potável, saneamento, alimentos, educação, transporte, lazer, emprego fixo e seguro. Ou seja, vivem em piores condições sociais, ambientais e sanitárias (BUSS, 2007). Ainda nesse processo, a violência só aprofunda a segregação, em que os mais atingidos são os moradores das favelas, já vulnerabilizados e cada vez mais estigmatizados e colocados à parte da "cidade formal". Nas favelas, onde o trafico de drogas é presente a discriminação, a violência e a pobreza levam a uma situação próxima ao isolamento social (GOMES, 2013).

DSC. 12 A discriminação e solidariedade, sem perder a dignidade

Gosto de morar aqui, apesar de o povo discriminar muito. Ontem mesmo a minha sobrinha foi pra o MAXI ${ }^{3}$ com meu cunhado e eles deram uma nota de 20 reais, aí a mulher de lá chamou outra e disse: vem olhar se essa nota aqui é falsa ou não. Ainda essa semana um vizinho meu foi lá e quando ele foi colocar crédito no telefone a moça disse: está cheio de mosca aqui. Outro dia eu fui para MAXI fazer uma comprinha de 50, até com 20 reais eu vou, comprar sabão em pó, aí tinha umas meninas que

\footnotetext{
${ }^{3}$ Grande supermercado localizado na via de acesso à Comunidade Mangabeira e ao centro da cidade de Arapiraca.
} 
disseram: não sei como esses meninos aguentam ficar dentro da caçamba de lixo, mas todos fedem que nem lixo. Foi aí que eu disse a ela: eu sou do lixão, mas nem por isso estou fedendo, me cheire. Eu moro no lixo, mas não me falta um perfume da Natura ou Boticário. E elas ficaram todas descabreadas, logo quatro moças. Elas não podem dizer isso, até porque tem muitos do lixo que andam mais bem vestidos do que elas. Eu me incomodo com esse preconceito, porque aqui tem muita gente boa. Tem gente da rua que vem pedir auxílio aqui e todos ajudam. Naquela campanha das enchentes que teve, muita gente daqui se uniu pra ajudar. Então ninguém aqui é morto de fome, é fedorento, é bandido e tudo isso eu escuto na rua. E eu digo que moro no lixão com muito orgulho. Eu fiz uns cartões aqui do Hiper e do Banco do Brasil e disse que eu era catadora de lixo e fui aprovada e nem fui bem vestida.

Ao residir na comunidade da Mangabeira, os moradores ainda enfrentam o preconceito de viver uma relação de proximidade e de subsistência pela reciclagem de materiais no lixão da cidade de Arapiraca. Essa atividade carrega consigo uma carga de preconceito social que se associa à sujeira, restos e pobreza. Porto et al. (2004) também identificou em seu estudo que $31,0 \%$ dos entrevistados mencionaram problemas com preconceitos decorrentes do fato de trabalharem no lixo, ou ainda carregarem o rótulo de pobres. Esses elementos são traduzidos em sentimentos que fazem com que se comparem ao próprio lixo e tentam resgatar sua dignidade simbolicamente, com o uso de perfumes de marcas nacionalmente conhecidas, que não fazem parte de seu alcance financeiro, mas são consumidos para afastar o incômodo de mau cheiro exalado pelo lixo deteriorado. Era de se esperar que eles desenvolvessem estratégias coletivas ou individuais de defesa, negação, sublimação, para suportar o cotidiano (SANTOS; SILVA; 2011).

As mulheres do deste estudo ainda fazem referência à necessidade da profissionalização da atividade de catador como forma de melhorar sua imagem pessoal e sua dignidade. A imagem negativa da sociedade sobre os catadores interage com a autoimagem que ele formou de si próprio. Quando 
não organizados, são vistos como marginais à sociedade. No entanto, ao se organizarem, também sofrem discriminações (VELOSO, 2005).

A solidariedade, aqui aparece como um sentimento que é expresso como forma de orgulho de poder contribuir ou ajudar a outras pessoas. Medeiros e Macedo (2006), em sua pesquisa, também encontaram interações simbólicas ambíguas dos catadores vítimas de preconceitos, como as relações de inclusão/exclusão, saúde/doença, orgulho/humilhação.

$\mathrm{Na}$ Comunidade Mangabeira, a média de pessoas que residem por moradia é de quatro a cinco $(4,6)$ pessoas por domicílio, dados iguais ou bem próximos aos 4,3 e 4,6 encontrados em famílias de catadores nos estudos de Porto et al.(2004) e Santos et al. (2013), respectivamente. Dados do Ministério da Saúde, coletados pela da Pesquisa Nacional de Demografia e Saúde da Criança e da Mulher, realizada em 2006, encontrou que 53,9\% das famílias beneficiárias do PBF no País possuíam até quatro membros e $42,6 \%$ de cinco a oito. E apontam que os domicílios com maior número de componentes são aqueles com menores recursos financeiros para dividir entre seus membros (BRASIL, 2008). Ademais, os novos arranjos domésticos, nos quais filhas solteiras, separadas, mães solteiras, filhos separados que retornam à família trazendo seus filhos, além de genros, noras e outros integrantes, trazem desafios para o contexto familiar de pobreza (IBASE, 2008).

DSC. 13 Quem mora em barraco e aceitar, vai morar no Brisa do Lago

Quem morava em um barraco foi morar no Brisa do Lago ${ }^{4}$. Não foram todos ainda, mais boa parte já foi. Eu acho bonzinho, cada um tem o seu teto, graças a Deus e é tudo sossegado, na sua casa. Porque aqui é tudo cheio de coisa, papelão, escorpião, cobra de duas cabeças, tudo isso aqui. Quero que todo resto vá para lá também. Até eu queria estar morando no Brisa, minha irmã fala direto que gosta de lá, eu não fui

\footnotetext{
${ }^{4}$ Conjunto habitacional construído pela Prefeitura Municipal de Arapiraca, com recursos do Governo Federal - Programa Minha Casa, Minha Vida, para retirada dos moradores que ocupam barracos no bairro da Mangabeira.
} 
porque eu moro em uma casa e não quis me desfazer da minha casinha. Já tem gente que não quer ir, acha muito longe e não quer ir para um canto que não conhece ninguém. Por isso não aceitaram ir. Outros estavam morando lá e já venderam e voltaram para cá, não gostaram de lá por ser longe do trabalho.

$\mathrm{O}$ número de pessoas por domicilio na Mangabeira sofre influência direta da facilidade de aquisição de moradias improvisadas, os barracos. Mesmo morando em barracos diferentes, as relações familiares de ajuda mútua são de extrema importância para garantia da sobrevivência dos grupos familiares e seus arranjos domésticos. Esse é um dos motivos pelos quais muitas famílias que recebem casas do governo, em pouco tempo, retornam para suas antigas moradias. Uma vez que as relações sociais são vistas como algo aberto e subordinado a um reconhecimento continuo, por parte dos membros da comunidade, para algumas pessoas, receber a casa nova, significa encontrar o sossego desejado, mas, como não encontram o que desejam, redefinem o significado da nova casa, ao vivenciarem as dificuldades de residir distante de seu trabalho, em novo contexto de vida.

O conjunto habitacional em questão, Brisa do Lago, foi construído em local afastado da cidade e da Mangabeira, por privilegiar a especulação imobiliária. É um local de moradia mais barata por não possuir infraestrutura, com falta de acesso, mas com a proposta de construção de escolas, postos de saúde, em longo prazo, após entrega das casas. Motivos que levam as famílias a venderem essas residências e voltarem a residir na Mangabeira. A segregação urbana e ambiental é uma das características mais importantes de desigualdade social, pois isso leva à população mais vulnerável a ter pouco acesso a serviços básicos e infraestrutura urbana básica, resultando em falta de saneamento, esgoto inexistente e difícil acesso aos serviços de saúde, entre outros (SANTOS et al., 2013).

\subsubsection{Enfrentando a fome.}

Toda a vulnerabilidade que essas mulheres e seus filhos estão expostos pode ser percebida nos DSC sobre a FOME. Ter uma vida 
permeada de insegurança alimentar faz com que esse grupo de mulheres recorra a estratégias para se afastar dessa situação, que vão desde pedir esmolas, a consumir alimentos encontrados no lixão, recorrer à solidariedade de algumas pessoas ou ONGs, até a descrição de sua carga de responsabilidade como mulher provedora. Essa vivência é carregada de significados marcantes que podem ser mais bem vistos nos DSC elencados abaixo.

DSC. 14 A fome é uma dor infeliz

Já chegou a faltar tanto dinheiro para medicamento, como até mesmo o que a gente comer, uma mulher sozinha com tanto filho. $O$ salário era bem pouquinho, quando a gente pegava naquele dinheirinho, mal dava para comer. Eu não sinto vergonha de dizer que eu mesmo dormia sem tomar café, mas para as crianças tinha que ter. É uma coisa muito ruim, porque chegava dia de minhas meninas pedirem alguma coisa dentro de casa e não ter. A fome é uma dor infeliz, a fome é uma dor tão grande, é uma dor tão tirana. É doído a gente procurar os quatro canto da casa assim e ver só água dentro do pote, nem sal na saleira ter, o marido parado eu parada e sem ter quem dê, meu Jesus Amado, eu disse pronto, chegou o dia agora de morrer, eu e meus filhos e tudo, mas meus filho não morre não, creio em Deus pai, pedi tanto a Deus, tanto, tanto, eu pedi a Deus com fé, eu morrendo em cima da cama, bolava de um lado e meus filhos dormindo e eu pedindo Deus com força e fé: meu Deus, não deixe eu morrer. E eu peguei num sono, parecia que eu tinha comido um boi naquela hora, eu olhei assim quando os menino se acordar eles não vão me vê mais nesse mundo, eu não vou mais está aqui, mas Jesus me confortou naquela hora, Jesus é bom, Jesus é tão bom, ele tão maravilhoso que eu não sei agradecer ao meu Deus a bondade que ele fez comigo, só Deus mesmo.

A experiência de passar fome é interpretada como algo próximo "da morte". Para elas, a dor da fome é tamanha, que, somente morrendo, para conseguir suportá-la, o que 
significa ter que sublimar a dor. As lembranças e a insegurança de vivenciar a mesma situação de fome provocam um sentimento contínuo de medo de voltar a experienciá-la. A fome vivenciada pelas catadoras de Mangabeira também é vivenciada por outras populações de catadoras no Brasil, como na pesquisa de Santos et al. (2013), na qual verificou que $75,5 \%$ das familias catadoras estão expostas à insegurança alimentar. Outras pesquisas, realizadas com outros grupos sociais que sofrem iniquidades, ressaltam a fome como uma necessidade de primeira ordem. Mas não se pode ficar limitado, tão somente solucionar necessidades mais imediatas, pois para o alcance de resultados efetivos é imprescindível mudanças na lógica das políticas sociais (CASAS; KLIJN; 2006; ROSA et al., 2005).

Assim como em todas as situações difíceis e sem solução e que precisam ser enfrentadas, existe sempre a possibilidade de recorrer à fé em Deus, como forma de ter a esperança na solução e superação de seus problemas. Portanto, a fé em Deus significa conforto para as situações mais difíceis de serem superadas. Alguns estudos apontam a religião /espiritualidade como um importante apoio nos momentos difíceis. A fé e a esperança trazem um conforto que ajuda a aliviar o sofrimento e a dor causados pelo enfrentamento dos problemas (PESSINI, 2007; PRAÇA; GUALDA, 2000).

É possível apreender, pela fala das mulheres, contidas no DSC. 15, que entre as inúmeras necessidades enfrentadas, a fome está muito presente no dia a dia dessas famílias. Como um sentimento que beira ao significado de dor, a fome tem de ser superada para que as pessoas não pereçam e o seu enfrentamento implica na adoção das medidas que estiveram ao alcance, pois é uma necessidade imediata e cotidiana.

DSC. 15 Pedia esmola para alimentar os filhos

Quando eu cheguei aqui eu morava em um barraquinho lá em cima e chegou um dia que não tinha o que comer, aí eu achei uma bolsa de charque no lixo e trouxe para casa e foi com que eu comi. Quando achava um pedacinho de carne, alguma coisinha trazia e a gente comia, vai fazer o quê? Era muita dificuldade, saía com o mais velho para pedir e poder 
dar comida a eles, eu não ia deixar os meninos morrerem de fome e tinha gente que me dava. Mas não é muito bom não, pedir esmola, porque hoje mesmo, às vezes eu estou na rua, que eu cato material na rua e eu vejo mulheres tão nova pedindo, eu digo: tá vendo e eu já pedi muito. Mas hoje eu não tenho mais coragem, eu vejo as mulheres tão novas, boas de arrumarem um emprego e trabalharem e não viver pedindo, eu acho feio. Certo que eu já passei por isso, mas hoje mesmo, eu sinto vergonha do que aconteceu.

Dessa forma, as mulheres relatam suas alternativas, de ordem prática, para suprir esta necessidade, não só delas como da própria família, em especial das crianças, e o que está mais próximo, é a busca de alimentos no lixão. Essa ação representa um impulso autônomo que depende apenas de sua iniciativa e o encontro da oportunidade, como o de achar alimentos disponíveis em possível condição de consumo.

Isso representa a resignação diante da fatalidade da condição em que vive e a possibilidade de sobrevivência, mesmo que seja humilhante e reconhecidamente inadequado, mas ainda melhor do que perecer na fome.

Outra alternativa é a esmola. A experiência de pedir ajuda na rua a estranhos e depender da solidariedade e do tratamento a ser recebido do outro parece ser mais degradante do que catar coisas na rua ou pegar restos de alimentos no lixo. Esse ato é adjetivado como uma experiência ruim, e passível do julgamento do outro.

O pedir esmola é algo transitório que tende a ser abandonado assim que possível e provoca o sentimento de vergonha, especialmente diante da possibilidade de ter outra alternativa que mostre a sua capacidade em produzir, por ela mesma, o recurso de autossobrevivência. Por isso, é capaz de observar outros pedintes e, apesar de compreender a situação do outro, recrimina a passividade e submissão de pedir esmola, ao invés de buscar sua sobrevivência com um mínimo que seja de autonomia.

A ingestão de alimentos do lixão indica a violação dos direitos humanos, uma vez que a Lei n. ${ }^{\circ} 11.346 / 2006$ define segurança alimentar como o acesso a alimentos de qualidade e socialmente sustentável (BRASIL, 2006). Vários outros estudos também apresentam a mesma 
realidade de consumo de alimentos achados no lixão, em sua maioria, de grandes supermercados, tendo suas datas de validade vencidas (PORTO et al., 2004; DALL'AGNOL;FERNANDES; 2007; REGO et al., 2002)

Alguns estudos, ao analisarem o comportamento do consumo de alimentos do lixão, os relacionam ao vínculo que esses sujeitos estabeleceram com o lixo, ou seja, as condições sociais desses trabalhadores determinam o aproveitamento intenso dos rejeitos (DALL'AGNOL; REGO et al., 2002).

Assim é possível perceber os diferentes significados que são atribuídos por essas mulheres ao utilizarem essas diferentes estratégias de conseguir alimentos. Ao pedir esmola, elas se submetem a um ato público que está condicionado a vontade do outro que pode ou não fazer a doação da esmola. Além disso, ao se expor publicamente, essas mulheres sentem-se vulneráveis a julgamentos, como o que ela mesma reproduz, apesar de ter vivenciado tal situação. Já ao consumir alimentos do lixão, elas fazem isso de forma reservada, sob seu único julgamento do alimento que pode ou não ser consumido, após sua avaliação, e dentro do seu dia a dia de trabalho. Outra alternativa é aceitar ajuda, como abordado no DSC. 16.

\section{DSC.16 Vivendo da ajuda dos filhos de Deus}

Estou vivendo da ajuda dos filhos de Deus, que querem me ajudar, da minha menina, que me ajuda e dá um quilo de açúcar, me dá um pacote de feijão quando tem, quando não tem não dá. Quando não, os amigos do bem que vem de São Paulo que me dão cinco quilos de arroz, um pacote de fubá, óleo e um pacote de macarrão. Às vezes, minha mãe ajudava, nós sempre nos ajudamos. Quando fiquei grávida e muito pesadona, deixei de trabalhar e chegou até a faltar sal em casa, aí juntava os vizinhos, que gostavam muito de mim, e traziam alguma coisa para mim, alimento, roupa de bebê e assim eu fui levando e quando não tinha, a gente ficava do jeito que Deus quisesse. A minha sorte é que às vezes chega às pessoas para socorrer e ajudar, senão eu estava pior ainda.

A solidariedade faz parte do dia a dia dessas famílias. E é através dela que é possível superar tantas adversidades. Ela ocorre no seio familiar, 
dentro da própria comunidade, entre os vizinhos e/ou de outras pessoas ou ONGs que conhecem a dificuldade vivenciada por essas famílias e ajudam algumas até de forma regular, como pôde ser percebido no DSC. 16.

Receber ajuda dos outros para sobreviver faz parte da dinâmica desse grupo, que está sempre precisando e ajudando, como expresso em suas falas, “nós sempre nos ajudamos". Em alguns momentos, essa ajuda alheia é a única forma de garantir seu sustento. Assim, receber ajuda é interpretado como algo rotineiro, que faz com que a vida não fique pior, ou seja, é possível, assim, ir sobrevivendo, menos degradante que outras alternativas.

Mesmo que essa comunidade receba frequentemente contribuições vindas de vários movimentos sociais, como ONGs, esse tipo de ajuda tem caráter pontual, o que não garante a certeza de uma contribuição estável e regular, o que gera uma vivência de sentimentos de insegurança, para aqueles que precisam dessas contribuições para conseguir viver. Nessa vida de incerteza, diante da sobrevivência, só Deus pode conformar.

Todo esse conjunto de elementos é visto no DSC. 17, em que a experiência de vida dessas mulheres, moradoras na Comunidade Mangabeira, retrata uma existência de sofrimento e privações. De luta solitária, muitas vezes, mesmo acompanhada de parceiros e filhos.

DSC. 17 Pobre tem que trabalhar: Trabalho para viver

Eu dou da comida a tudo, para os filhos, para os netos, sou eu que crio, educo, tudo sou eu. Só eu trabalho para sustentar a casa, as crianças, é só eu mesmo aqui. Toda vida eu fui sofredora para criar meus filhos e é só trabalhando.Tem vez que não tenho tempo nem de pentear o cabelo. Nas duas gestações trabalhei, pegava balde de 20 litros, que uma mulher grávida não pode pegar, puxava água. No dia de eu ter esse segundo filho meu, puxei água de cacimba. Pobre - minha filha - é assim mesmo, não fica de resguardo, tem que trabalhar. Mesmo com resguardo eu nunca parei de trabalhar, com 15 dias eu fazia uma coisa, fazia outra e já ia para o lixo, ia trabalhando devagarzinho procurando alguma coisa. Sempre fui sozinha para tudo. Quando eu chegava do hospital, não tinha esse negócio de ir pra cama deitar não, já colocava o menino na cama, 
tomava banho e ia para a beira do fogo fazer comida para comer, no outro dia já ia para o tanque lavar roupa. E dou graças a Deus, que não estou pedindo miséria, Deus tá vendo que é verdade, não estou passando fome, não é o suficiente para comprar tudo que se deseja, mais para a alimentação dá. E se o lixão chegar a fechar, eu arrumo outro emprego e trabalho para viver.

Suas falas traduzem uma história de trabalho intenso que toma conta de suas vidas, pois elas são, em algumas situações, a única fonte provedora ou a provedora principal de seus lares, responsabilidade assumida, que provoca um sentimento de resignação e de satisfação com muito pouco, com o alcance do necessário, restrito para a sobrevivência própria e daqueles pelos quais zela. Nessa perspectiva, de buscar o próprio sustento e prover o sustento e atendimentos das demais necessidades básicas para si e família, ela se entrega ao trabalho e sublima sua individualidade feminina, pois a amplia para uma dimensão de ser mulher que cumpre com sua missão de produção e reprodução, de forma solitária e incessante.

Mesmo na condição de grávida, continua o trabalho, enfrentando o ambiente insalubre e inadequado para o estado em que se encontra, reproduzindo a situação de outros aterros, resultado da pesquisa de Porto et al. (2004) em que 43,5\% das mulheres trabalhadoras referiram ter trabalhado durante a gravidez, sendo que algumas delas repetidas vezes .

Com base no DSC.17 apreende-se que, com o exemplo da sua lida na gravidez e pós- parto, ela demonstra como arrisca seus limites de forças, já que tem de enfrentar as situações com as quais depara, sem ter outras opções ou poder contar com ajuda de outras pessoas, mesmo se colocando em situações de risco à saúde.

Ser pobre, nesse cenário extremo de desqualificação de força de trabalho e poucas oportunidades de melhoria de rendimento, significa ter de se contentar em ter o mínimo ou o essencial para viver. E isso, por sua vez adjetiva a vida e a pessoa como sendo pobre. No entanto, há um divisor entre a pobreza e a miséria. A pobreza é aquela situação em que a condição “não é o suficiente para comprar tudo que se deseja” e que se diferencia da condição de miséria, quando a fome qualifica a condição de miserável. 
Nessa perspectiva, a mulher tem no trabalho intenso a oportunidade de viver mesmo que na pobreza, seja onde for que exerça suas atividades, desde que produza o suficiente para ter, pelo menos, o alimento, o que a diferencia e afasta da miséria. 


\subsection{EXPERIÊNCIAS MATERNA DA GESTAÇÃO, PARTO E CUIDADOS COM FILHOS}

O comportamento do grupo que vivencia a pobreza pode ser compreendido com base na descrição do contexto de vida dessas mulheres aprofundada no desvelar de suas falas, sobre suas experiência ao enfrentarem uma gravidez não planejada, um parto doloroso, abortos, adoecimento e mortes de filhos. Assim, a descrição desses momentos de vida é interpretada como de muito sofrimento e dores, que em muitos momentos são enfrentados com resignação. A maternidade tem um significado de aumento na demanda de responsabilidades dessas mulheres, que chega de forma planejada ou não, mas que faz parte de suas vidas. As experiências do ciclo reprodutivo reclama, além das carências socioeconômicas, para oferta e acessibilidade à assistência à saúde materna e infantil.

\subsubsection{Ciclo anticoncepção, concepção e aborto.}

A Tabela 4 apresenta a distribuição de número de partos, e observase que $71,4 \%$ das mulheres tiveram mais de três partos, o que confere ao grupo uma taxa de fecundidade de 4,22. No Brasil, os resultados da Pesquisa Nacional por Amostra de Domicílios (PNAD) de 2008 apontam a queda da taxa de fecundidade total, para níveis abaixo aos de reposição $(2,1$ filhos por mulheres, atingida em 2003), alcançando 1,83 filhos por mulheres em 2006. Essa queda iniciou-se na segunda metade da década de 1960 e está implicando em uma desaceleração do ritmo de crescimento da população brasileira (IBGE, 2010). Segundo Berquó e Cavenaghi (2004), embora haja tendência à homogeneização das taxas de fecundidade em níveis muito baixos, em todas as regiões brasileiras, estudos referem que ainda existe um diferencial entre grupos populacionais, com cerca de 3 milhões de mulheres brasileiras em idade reprodutiva, que vivenciavam uma alta fecundidade (cinco ou mais filhos). 
Tabela 4 - Distribuição das mulheres moradoras da Comunidade Mangabeira, segundo paridade, Arapiraca, 2014

\begin{tabular}{l|l|l}
\hline Número de partos & Mulheres \\
\cline { 2 - 3 } & N & $\%$ \\
\hline Até 2 partos & 10 & 28,6 \\
\hline De 3 a 4 partos & 14 & 40 \\
\hline Mais de 5 partos & 11 & 31,4 \\
\hline Total & 35 & 100,0 \\
\hline
\end{tabular}

O Gráfico 1 apresenta a média do número de partos por faixa etária, o que revela que as mulheres mais velhas têm um número maior de filhos, o que sugere que a taxa de fecundidade do grupo pode estar diminuindo, seguindo a tendência nacional. A fecundidade mais elevada entre a população pobre, menos escolarizada, com menor nível de consumo e piores condições habitacionais, é uma realidade constatada em todas as pesquisas sobre o comportamento reprodutivo no Brasil. A literatura mostra que, em grande parte, esta maior fecundidade se deve não apenas à falta de acesso aos serviços de saúde sexual e reprodutiva, mas também acontece em razão da falta de perspectivas profissionais e educacionais, assim como de um projeto de vida que possibilite o progresso cultural e material dessas mulheres jovens (ALVES; CAVENAGHI; 2013; SOARES, 2013). 
Gráfico 1- Distribuição da média de partos, por faixa etária, das mulheres moradoras da Comunidade Mangabeira, Arapiraca, 2014

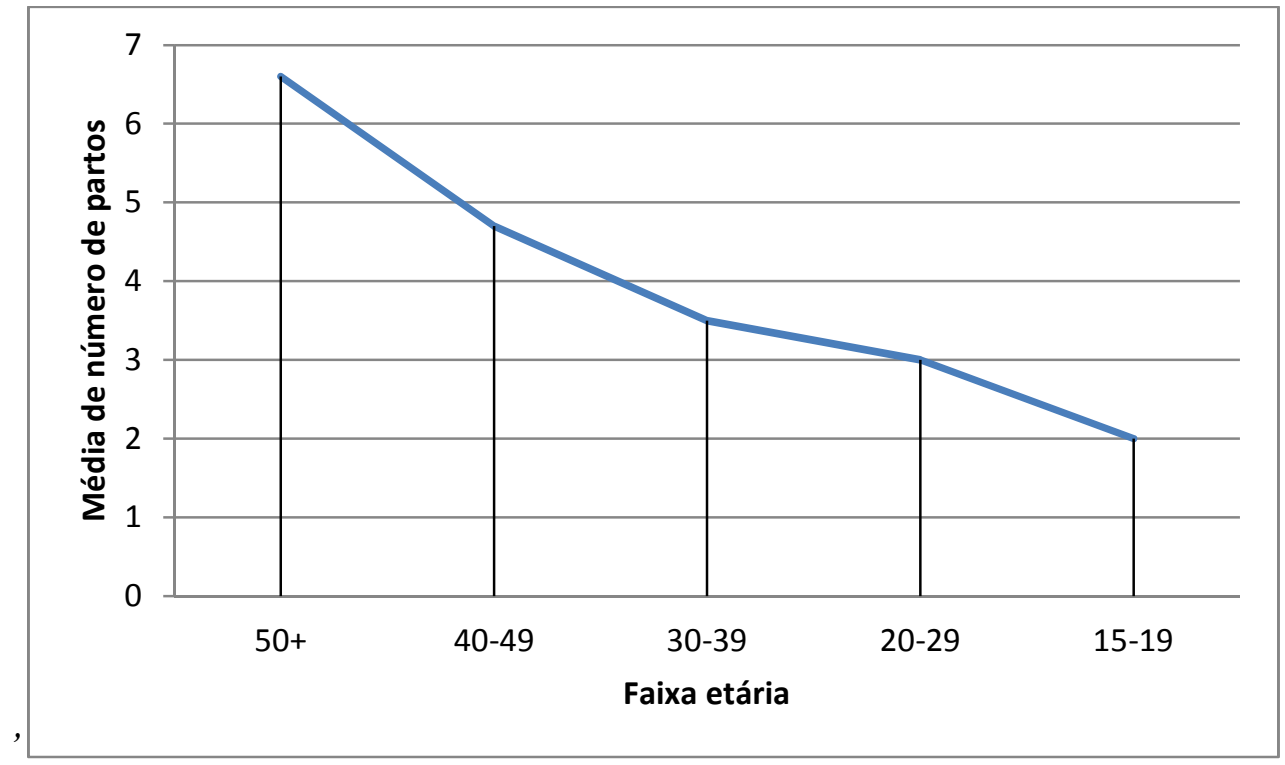

Muitas mulheres engravidaram ainda na adolescência. A pesquisa nacional de demografia e saúde da criança e da mulher, PNDS 2008, identificou que a média de idade da primeira relação sexual das mulheres brasileiras foi de 17 anos (BRASIL, 2010). Alguns estudos estabelecem uma relação entre idade, primeira relação sexual, primeira união, primeiro filho e fecundidade futura, pois, quanto mais cedo ocorre a primeira relação sexual e a primeira união, maior a oportunidade de o primeiro nascimento também acontecer mais cedo e maior serão as circunstâncias favoráveis a um número alto de filhos (OPAS, 2007; CAETANO, 2004).

DSC. 18 Engravidando sem esperar e correndo o risco de nova gravidez

Naquele tempo, a gente só engravidava porque não tinha remédio, era um sufoco. No começo eu fazia muita coisa para evitar, mas depois comecei a me prejudicar e parei. Quem vive tomando remédio para evitar gravidez não adianta dizer que não quer, porque às vezes engravida até tomando remédio. A pessoa que não é operada nunca pode dizer que não quer outro filho. Por isso eu terminei engravidando, foi sem esperar, nem eu mesmo sei direito como foi, mas quem namora, que não usa 
preservativo, às vezes o que ganha é isso. Eu fiz de tudo para evitar, eu estava tomando remédio, mas quando é tempo de festa, as doutoras saem de ferias e fiquei sem remédio e não podia comprar sem dinheiro, aí pronto!.. Foi na hora que eu engravidei. Eu ainda estava dentro da casa da minha mãe, quando pensei que não estava grávida, esperei a menstruação, só a barriga crescendo, minha mãe mesmo reclamava muito, começou a brigar. Eu fiquei com bastante medo de engravidar, mais terminou acontecendo, porque sempre você fica com a lembrança do que você passou no último parto. Eu pensava em não ter, tanto que passei um tempo livre, que era para ter ido operar, mas não fui, porque quando Deus permite que tem que ser assim, é assim.

Percebe-se, algumas mulheres do estudo não desejavam uma nova gravidez, que ainda é reforçada com a lembrança da experiência dolorosa do seu último parto, o que fortalece o sentimento de não querer engravidar. Assim essa mulher interpreta a gravidez não planejada como algo que aconteceu independente de sua vontade, mas permitido ou designado Deus, um fenômeno sobre o qual ela não tem domínio e com o qual tem que se conformar, assim como com sua condição atual, mesmo que não tenha tido a intenção de provocá-lo, o que, mesmo assim, não exime a mulher de sentimento de culpa, por não ter evitado uma nova gravidez, no momento em que isso poderia ter siso feito.

Algumas mulheres utilizam métodos contraceptivos, mas abandonam ou não conseguem mantê-los. Para Osis (1999), muitas mulheres vivenciam claramente a necessidade da anticoncepção. E sua experiência contrapõe-se à angústia de não saber como controlar efetivamente a sua fecundidade, com base nos insucessos frequentes em conseguir manter o uso constante de algum método contraceptivo e, principalmente, em gravidezes indesejadas. Essa análise também foi feita no estudo de Mani et al. (2013), em que a pobreza influencia negativamente na adesão de esquemas terapêuticos, assim como na má utilização de cuidados preventivos de saúde.

Segundo Soares e Schor (2013), o desconhecimento sobre as questões relacionadas aos direitos e à saúde reprodutiva e sexual contribui para a manutenção das desigualdades de gênero no controle sobre a 
reprodução, especialmente nas camadas populares, nas quais se inseria a maior parte das entrevistadas desta pesquisa. $O$ que pode ser claramente percebido no DSC. 18, em que esse grupo de mulheres em nenhum momento expõe em cena a figura masculina, no contexto da anticoncepção.

Essa mesma autora evidencia e ainda apresenta em seu estudo que a redução da taxa de fecundidade relacionada às gestações indesejadas ou não planejada, esta relacionada à garantia de maior escolaridade, trabalho formal e melhoria de renda, além do acesso a informações sobre direitos e saúde reprodutiva, relacionadas às questões de gênero, e a métodos contraceptivos adequados para os casais.

DSC. 19 Fiz laqueadura para não ter mais filhos

Quando eu falava de me operar, o povo fazia muito medo, dizia que pessoa que se opera, mais nova fica doente, às vezes morre, aí eu ficava com medo. Se eu tivesse a experiência, se tivessem me orientado era para ter me operado dos outros filhos, mas na época nem me preocupei em me operar. Esse último, eu me operei dele, o doutor disse: faça de tudo para você não ter mais um filho, porque se você engravidar você morre. Quando ele disse isso, eu já entrei em desespero. Por isso eu optei por cesáreo e fiz a laqueadura, para não ter mais filhos. Deu tudo bem, se eu soubesse que era do jeito que foi, tinha me operado há mais tempo.

A laqueadura significa, para essas mulheres, a certeza e a segurança de não terem mais filhos, mas, ao mesmo tempo, por ser um processo cirúrgico, envolve o medo que advém de crenças de que laqueadura é um processo que vai de encontro ao natural, que é ter quantos filhos Deus permitir. Assim, a mulher que decidir pela laqueadura pode ter como castigo uma morte prematura.

Ao mesmo tempo, existe uma dificuldade de acesso à realização desse procedimento pelo sistema de saúde pública, por isso poucas conseguem. Portanto, algumas dessas mulheres, ao se depararem com a possibilidade de realizar a laqueadura por indicação médica, sentem-se mais seguras em superar suas crenças. A experiência da cirurgia e o seu resultado parecem 
constituir algo positivo, pois lamentam não ter tido a possibilidade de tê-la realizado há mais tempo.

A laqueadura tubária é atualmente o método contraceptivo mais usado no Brasil. E alguns estudos apontam que a laqueadura representa para as mulheres a única alternativa confiável, segura, de evitar uma nova gravidez, uma vez que o papel reprodutivo é socialmente imposto às mulheres, assim os insucessos acabam sendo atribuídos à sua incapacidade pessoal de controlá-lo, por isso a laqueadura aparece como a melhor opção. Por ser feita pelo médico, a sua eficácia se legitima e, ao mesmo tempo, absolve a mulher da culpa relativa às possíveis falhas dos métodos anticoncepcionais (BEMFAM/MACRO, 1997; OSIS, 1999; SERRUYA, 1996). Todos esses achados também foram vistos no DSC. 19.

Outras pesquisas mostram que diante da dificuldade de acesso da laqueadura nos serviços de saúde pública, muitas mulheres são esterilizadas por ocasião da cesárea, assim muitas cesáreas foram realizadas com o propósito exclusivo de realizar a ligadura de trompas (HARDY et al., 1993; BEMFAM/MACRO, 1997). Serruya (1996) ainda afirma que, conseguir se laquear, era visto como o fim de uma guerra, da batalha cotidiana que as mulheres travam para controlar sua fecundidade. A mesma perspectiva foi também observada por Minella (1998) entre mulheres esterilizadas de Florianópolis, SC, bem como em outro estudo realizado em Campinas, SP (Costa et al., 1995), com mulheres que recentemente haviam sido esterilizadas, as quais consideravam a laqueadura como fator tranquilizante, que as desobrigava da preocupação diária com a anticoncepção.

Diante de uma vivência de dificuldades que dizem respeito à sobrevivência, sua e de sua família, já expressas anteriormente, apenas duas mulheres do grupo estudado, ainda queriam ter mais filhos, e expressam isso em suas falas: "Queria ter mais um filho agora, foi porque não veio mesmo. Só evitei até a minha filha fazer oito anos, depois não evitei mais e não engravidei ". O espaço de tempo longo de uma gravidez para outra pode facilitar os cuidados com a criança, porém a demora em ter sucesso no seu planejamento à espera de uma nova gravidez pode gerar ansiedade e desânimo. Os motivos que levam essas mulheres a quererem uma nova 
gravidez estão relacionados à vontade do novo companheiro em ter um filho do casal. Assim, a mulher, pensando em fortalecer essa nova relação, deseja uma nova gravidez, mesmo sem condições financeiras: “o sonho dele, se fosse por ele, eu já estava perto de ganhar um menino”.

Da Silva (2013) levanta questionamento sobre essa situação, porque um casal com poucos recursos pode ansiar por ter tantos filhos, o que certamente lhe trará mais dificuldades de sobrevivência. E encontrou a mesma resposta das mulheres deste estudo, ou seja, o desejo de agradar ao marido talvez pese mais do que um real instinto materno. Este estudo aponta que, além das dificuldades econômicas para a criação das crianças, nas camadas populares, predomina uma relação tradicionalista em que o homem é o provedor e a mulher aquela que cuida da casa e dos filhos. Assim, toda maternagem está a cargo das mulheres.

\section{DSC. 20 Segui grávida enfrentando os problemas da gravidez.}

Foi normal a gravidez, eu brincava, eu pulava corda, eu me divertia, ia para os "shows", na segunda gravidez do mesmo jeito. Dela foi melhor que das outras, eu não adoeci. Enjoei pouco, da outra eu vomitava muito e ficava enjoada. Praticamente, eu passei três meses no hospital, porque até água que eu tomava eu vomitava. Da terceira gravidez para cá, eu sinto mais diferente, me sinto mais doente, agora o que mais sinto é dor no pé da barriga. Eu tive uma gravidez muito doente, sentia uma agonia, uma canseira, o coração acelerado, aí eu ia para a doutora e ela dizia que estava tudo normal e eu passava um dia em casa e o outro dia no hospital. Dos quatro meses para os cinco meses, foi que eu melhorei e segui o resto normal.

Ao seguir grávida e percebendo o crescimento da barriga, que simbolicamente representa a presença da criança, algumas mulheres, com base na sua interpretação, percebem que existem alterações entre diferentes gravidezes, de modo que, em algumas, é possível seguir a vida sem alterações; já outros processos gestacionais estão acompanhados de dor e incômodos. Com o passar dos anos, cada nova gravidez é vivenciada com 
mais problemas de saúde, elementos significantes de um processo que parece que não foi bem aceito, mas teve que ser enfrentado.

Esse mesmo estudo discorre sobre a necessidade do estimulo, por parte dos profissionais de saúde para que a gestante possa exercitar seu afeto com seu filho, "falando com a barriga", acariciando-a, alisando-a. Com estímulos que relacionem a afetividade à sabedoria popular que também adverte que sentir emoções "negativas" - como o medo, insegurança, nervosismo ou raiva no decorrer da gravidez - pode "prejudicar" o feto, “custando a evoluir" (CALVASINA, 2007).

Portanto, os profissionais de saúde desempenham um papel importante, nesse e em outros aspectos que foram descritos. E o pré-natal é o espaço para o desenvolvimento dessas relações de aprendizagem. Das 35 mulheres estudadas, $41,8 \%$ tiveram acesso ao pré-natal sem dificuldade, quando estavam grávidas. A falta total ou parcial de acesso ao pré-natal foi vivenciada por $58,2 \%$, o que pode aumentar o risco de desenvolvimento de problemas durante a gravidez e o parto, que poderiam ser evitados com acompanhamento adequado (Tabela 5). No Brasil, os dados sobre cobertura de pré-natal evidenciam um aumento de cobertura desse tipo de atendimento, em que gestantes brasileiras, com sete ou mais consultas de pré-natal, já são maioria, representando $57,1 \%$ em 2008, ao passo que em 2000 era 43,7\% (BRASIL, 2009).

Tabela 5 - Distribuição das mulheres moradoras da Comunidade Mangabeira, segundo acesso ao pré-natal por gestação, Arapiraca, 2014

\begin{tabular}{l|l|l}
\hline Pré-natal por gestação & Mulheres \\
\cline { 2 - 3 } & $\mathbf{N}$ & $\mathbf{\%}$ \\
\hline $\begin{array}{l}\text { Teve acesso sem } \\
\text { dificuldade }\end{array}$ & 54 & 41,8 \\
\hline $\begin{array}{l}\text { Não teve acesso } \\
\begin{array}{l}\text { Teve acesso só a algumas } \\
\text { consultas e exames }\end{array}\end{array}$ & 39 & 27,9 \\
\hline Total & $\mathbf{1 2 9}$ & 30,3 \\
\hline
\end{tabular}


DSC. 21 Pré-natal: como espaço de orientação e aprendizagem

Do meu primeiro filho eu fiz seis consultas e dela agora fiz só três. Só fiz dois exames de sangue, porque sem agente de saúde não estão marcando ultrassom, nem exame eu fiz. Eu fazia pré- natal, mas só que a doutora não tinha vaga para fazer o exame e eu também não tinha dinheiro para pagar. Era com as meninas do CRAS (Centro de Referência em Assistência Social), que eu conversava sobre tudo isso. Desse último, eu fiz o pré-natal os nove meses. Eu achei bom, atendia bem, todo mês eu ia fazer o pré-natal, exame e tudo. Eu fui orientada no pré-natal que fize assistia meio mundo de reunião sobre gestação. O agente de saúde fazia reunião com as gestantes e ele pedia para eu explicar porque já tive mais filho. Sempre tem mãe que tem dificuldade. $O$ doutor do posto disse que era para eu sempre amamentar quando nascesse. $O$ que ele orienta mesmo é durante os seis meses só amamentação e ensinando a estimular o bico do peito para sair leite, elas ensinavam, que você botasse essa roda do peito toda, não só no bico, aí não feria, botar o nenê para arrotar, botar o nenê para mamar de 3 em 3 horas, o enfermeiro sempre alertando, as consequências do nenê golfar dormindo e o golfo sufocar, mandou uma relaçãozinha com os cuidados do nenê também. Como eu já tive quatro, não tem mais que me orientar não, eu já sei um bocado de coisa quando nasce. Até oriento minhas cunhadas quando têm filho.

A dificuldade de acesso aos serviços de saúde é descrita no DSC. 21. Essas mulheres explicam que não conseguem o acesso ao seu pré-natal. A vivência de falta de acompanhamento de sua saúde reforça o sentido da falta de recursos financeiros, pois não há outra opção de serviço para acompanhar sua gravidez.

A baixa cobertura dos serviços de saúde, em especial a visitação dos Agentes Comunitários de Saúde, é sentida em várias locais do Brasil, assim como em outras populações que vivem em torno aos aterros e lixões (SANTOS et al., 2013). Um estudo filipino, realizado em comunidades pobres desse país, evidencia que as mulheres grávidas pobres têm necessidade de serviços adicionais durante o acompanhamento do pré-natal 
(DUAZO; AVILA; KUZAWA, 2010). O que só confirma a maior necessidade de acompanhamento de pré-natal em populações carentes.

Vale ressaltar que algumas mulheres da comunidade já têm uma aproximação com o Centro de Referência em Assistência Social (CRAS) ${ }^{5}$, assim, com a dificuldade de acesso aos serviços de saúde, algumas mulheres procuram resolver demandas, que deveriam ser resolvidas no pré-natal, com as assistentes sociais desse Centro, que assumem o papel dos profissionais de saúde, em seus serviços.

Quando conseguem o acesso aos serviços, essas mulheres participam de reuniões e chegam a contribuir, quando solicitadas pelos profissionais, contando sua experiência para outras mulheres, o que valoriza a sua participação no grupo e até reproduzem as falas dos profissionais sobre os cuidados com recém-nascidos e amamentação. Outro estudo identificou que as orientações quanto ao aleitamento materno prestadas no pré-natal estão diretamente associadas à satisfação com o apoio recebido pelas gestantes para amamentar, evidenciando a importância de um atendimento de qualidade (DA SILVA, 2013). Assim, a consulta de pré-natal foi apontada em outra pesquisa, como uma das oportunidades para que os profissionais de saúde possam identificar os fatores de risco para o desmame precoce e realizar simultaneamente ações educativas, demonstrando manejo da amamentação (LINHARES et al., 2013)

Para algumas mulheres, o processo da gravidez é interrompido com aborto. A Tabela 6 apresenta a distribuição do número de abortos que ocorreram com o grupo de mulheres em estudo, em que $45,8 \%$ tiveram um ou mais abortos. No Brasil, cálculos mostram que o índice de abortamento é de 31\% (DINIZ; MEDEIROS; 2010), um pouco menor que o encontrado neste estudo. Um estudo realizado com mulheres catadoras em aterros identificou, que, 21,2\% mencionaram ter tido aborto espontâneo na época

\footnotetext{
${ }^{5}$ Atua na comunidade como uma unidade publica que serve como porta de entrada do Sistema Único de Assistência Social (SUAS), nas áreas de vulnerabilidade e risco social, com um Serviço de Proteção e Atendimento Integral à Família (PAIF), que consiste em um trabalho de caráter continuado que visa fortalecer a função protetiva das famílias, prevenindo a ruptura de vínculos, promovendo o acesso e usufruto de direitos e contribuindo para a melhoria da qualidade de vida.
} 
que trabalhavam grávidas. Por isso, o autor sugere que esses abortos devem ser mais bem investigados, na perspectiva relacioná-los à insalubridade no trabalho no lixão (PORTO et al., 2004).

Tabela 6- Distribuição das mulheres moradoras da Comunidade Mangabeira, segundo quantidade de abortos, Arapiraca, 2014

\begin{tabular}{l|l|l}
\hline \multirow{2}{*}{ Quantidade de abortos } & Mulheres \\
\cline { 2 - 3 } & N & \% \\
\hline Nenhum & 19 & 54,2 \\
\hline 01 & 8 & 22,9 \\
\hline Mais de 2 & 8 & 22,9 \\
\hline Total & $\mathbf{3 5}$ & $\mathbf{1 0 0 , 0}$ \\
\hline
\end{tabular}

DSC. 22 Abortei por medo e desejo

Os abortos que tive, não senti nada, o único que não foi tão bom assim, foi os dois que eu abortei, abortei um de sete mês e um de três. $O$ de sete foi um desejo de comer a cocada quente eu não comi, aí abortei e o de três foi um medo que eu tive. Eu estava varrendo o terreiro, aí vinha uma cobra e quando eu me virei tive aquele medo e gritei pronto, abortei. O de três meses nasceu em casa mesmo, só o de sete que precisou ir (para maternidade).

As mulheres estudadas ao referirem à ocorrência de abortos, não estabelecem diferença entre abortos e natimorto. No entanto, todos os abortos mencionados, pelas mulheres do estudo, ocorreram de forma involuntária. A experiência do aborto é interpretada como um processo natural. Sendo assim, na perspectiva dessas mulheres, as causas ocorrem ao acaso, não sendo possível de evitá-las. As pesquisas realizadas no Brasil, sobre aborto, como a de Machado (2013), apontam que a ocorrência de abortos involuntários esteve associada à ausência de pré-natal, em consonância com a situação das mulheres da Mangabeira.

Outro aspecto interessante é que as mulheres deste estudo percebem que o aborto ocorre casualmente e de forma imprevista, não expressando sentimentos de perda e individualismo, mas como algo espontâneo, embora 
os estudos sobre o aborto revelem em seus achados, que seja espontâneo ou provocado, o aborto afeta a mulher de maneira profunda, pois traz consigo consequências físicas, psicológicas e sociais, (DAMIANI, 2005; FRANÇA, 2003).

DSC. 23 Mesmo o parto normal pode representar sofrimento

Eu tive três filhos em casa e os outros eu tive no hospital. Quando eu vim morar aqui, eu estava grávida e era longe do hospital e eu tive ela em casa com a parteira. Ela morava muito longe, mas quando ela tinha um tempinho deixava o serviço lá e vinha cuidar de mim. Os filhos que tive na maternidade foram de parto normal e só ia para maternidade quando já via o sinal que era para ter mesmo, às vezes era uma água quando a bolsa rompia, às vezes e era um líquido que saía. Por isso que era chegando e nascendo. Sempre quando eu sentia as dores a criança vinha logo. Já, desse agora, eu senti dor foi quase uma semana, foi a pior coisa do mundo, a pessoa sofre muito, fui para maternidade, aí me mandaram voltar. Completou os nove meses e eu não tive e estava muito inchada. Eu fiquei internada e elas estouraram a minha bolsa na cama, na mão delas, porque fizeram muito toque. Sofri um bocado. Depois de certo tempo eu já estava assim muito fraca e eu acho que estava no meio caminho e não dava pra fazer cesáreo. A enfermeira veio com a caixa de ferro e o médico terminou puxando o menino. Quase que eu e ele morríamos na mesa de parto, quando a mulher dizia força: força para menino nascer. Eu tremia mais que uma vara verde. Depois de muito pelejar foi que ele nasceu de pé. E tinha bastante enfermeira lá dentro da sala, para mim eram todas aprendizes, novinhas e ficavam tudo olhando $e$ eu lá agoniada, com dor e vergonha, pois elas ficavam olhando para as minhas pernas. Quando vem aquela dor, as enfermeiras ficam deixando você sofrer. E era só eu mesmo. Perguntaram a minha irmã qual deviam salvar, eu ou o bebê, aí ela disse: é melhor salvar a minha irmã e deixar ele, mas eles conseguiram salvar, só não disseram qual foi o problema. Sofri, mas cheguei lá. 
A maioria das mulheres relata ter seus filhos de parto normal (89,9\%). As mais velhas tiveram a experiência de ter parido em casa, com ajuda de parteiras leigas $(19,4 \%)$, mas a maioria têm partos em maternidades locais $(80,6 \%)$.

Os partos domiciliares eram justificados pela falta de acesso à maternidade. Ainda assim, as parteiras também se deslocavam de longas distâncias para a prestação de seus cuidados.

A experiência do parto envolve a possibilidade de risco e sofrimento, principalmente pela presença da dor. A mulher sente-se vulnerável diante do sofrimento, que chega próximo ao temor da morte. O sofrimento também pode ser causado pelo pudor com a exposição de seu corpo, o que gera sentimento de vergonha e agonia de estar sozinha, mesmo em um ambiente com tantas pessoas. Portanto, o parto é visto como uma situação difícil de ser enfrentada, e sentem um alívio vitorioso ao chegar ao seu final. No estudo de Silva (1997), é possível relacionar vários elementos com significados próximos ao encontrado no presente estudo a despeito do parto, como "tendo que enfrentar o parto" que é descrito como momento permeado de medo, sofrimento e temor de riscos de vida e morte.

\subsubsection{Doença e morte de filhos pequenos}

Após o parto, iniciam as preocupações e cuidados com os filhos. E são muitos os relatos que abordam o adoecimento de seus filhos. Alguns desses agravos que acometeram as crianças, o fizeram evoluir para o óbito. Em seus DSC, as causas das doenças não foram relacionadas ao seu contexto social, já o relato dos óbitos, além de também descritivos, já se percebe uma relação de sua ocorrência com o local de nascimento dessas crianças, como pode ser visto no DSC. 24 e 25.

DSC. 24 Cuidando dos filhos durante adoecimento

Eles viviam bastante doentes, desde um problema de garganta até infecção nos rins, esse menino já teve muito doente. Esse outro estava vomitando, com sangue nas fezes e com febre, minha sogra deu remédio 
de verme, só que eles tinham verme demais e ficaram desmaiando. Já esse teve pneumonia e de vez em quando tem cansaço. Tiveram até problema do sarampo e ficaram bem magros, sem querer comer nada. Eu sempre levo para o médico, eu cuido, faço lambedor, levo no posto, pego medicamento e elas se curam. Eu acho que agora tem mais recurso que antigamente, a vacina era de vez em quando, agora é sempre.

A alta morbidade das crianças em um ambiente tão insalubre é algo experienciado regularmente por essas crianças e mães. As dificuldades vão desde a doenças infectocontagiosas comuns, até problemas mais graves. A internação dos filhos é algo recorrente por essas mães, que vivenciam os cuidados com seus filhos. Corraborando com este estudo, Calvasina (2007) constata que existe um esforço materno para cuidar dos filhos, apesar da pobreza e da miséria em que vivem.

Essas doenças frequentes e rotineiras têm consequências negativas sobre o crescimento e desenvolvimento de seus filhos, aumentando assim o risco de morte por causas evitáveis. Além disso, essas crianças requerem maiores cuidados e gastos o que só aumenta a demanda de problemas enfrentados por essas mulheres e seus filhos.

Um dos elementos que diz respeito aos cuidados com filhos, junto dessas mulheres, é o serviço de saúde local. Nesse sentido, as mulheres percebem uma melhoria de acesso, utilizando a vacinação como exemplo, mesmo que a falta de vacinação, de alguns filhos, seja uma das causas citadas anteriormente, para suspensão do benefício da Bolsa Família. O estudo sobre as coberturas de vacina nas capitais nordestinas do Brasil define que as características da população influenciam as coberturas vacinais. Assim, os profissionais de saúde precisam estar atentos na identificação de baixa cobertura e da alta taxa de abandono, além da tomada de medidas que possam sanar esses problemas (QUEIROZ et al., 2013).

DSC. 25 Filhos morrendo novinhos.

Eu tive 13 filhos e morreu a metade, tudo novinho, só se criou cinco, um deles faleceu com um mês de vida, levou uma queda da cama e passou 
um vento nele, aí não teve jeito e morreu. Tinha outro com um ano e sete meses que era mesmo que tivesse nascido naquela hora, tudo devido à queda que levei grávida e fiquei doente, aí ele foi e morreu. Uns morreram assim com diarreia vomitando, morreu até de anemia e pneumonia, se internou e tudo, mais morreu. Os que morreram nasceram em casa, os que nasceram no hospital não morreu nenhum, óia!

Os dados sobre mortalidade infantil apontam a ocorrência de 25 óbitos infantis, sendo dois natimortos. Destes, 20 acometeram menores de um ano, e três com idade até dois anos. No DSC. 25, as mulheres relatam que vivenciam esses óbitos de forma natural, como se o óbito infantil fosse algo que tivesse que ocorrer com aquela criança. Os relatos são breves e tratam de descrever o óbito e sua causa de forma superficial, que, em sua maioria, está relacionada a doenças evitáveis. Entre as causas descritas, a diarreia esteve presente nos relatos de morte de cinco crianças, tres óbitos foram associados à pneumonia.

Alagoas tem o segundo pior Índice do Desenvolvimento Infantil (IDI) e é o estado brasileiro de maior taxa de mortalidade infantil do País (UNICEF, 2009). Em 2000, a taxa de mortalidade infantil era de 58,4 óbitos para cada mil nascidos vivos. Esse número era mais que o dobro da média nacional, de 27,4. Mas a média do estado escondia taxas ainda maiores, em especial em alguns municípios do sertão alagoano com mais de $60 \%$ desses óbitos. A situação era tão grave que foi considerada calamidade pública pelas autoridades estaduais e pelo UNICEF. Durante a última década, a melhoria obtida por Alagoas na taxa de mortalidade infantil foi muito significativa. De acordo com os Indicadores de Dados Básicos para a Saúde, a taxa chegou a 41,1 óbitos para cada mil nascidos vivos em 2007 e caiu para 21,5 no ano seguinte, o que significa uma queda de $48,3 \%$, no entanto, há muitos obstáculos a superar (UNICEF, 2012)

Kassar (2013) identificou, em seu estudo, que os fatores, que se mostraram associados à mortalidade neonatal em Maceió- AL, são decorrentes de assistência inadequada ao pré-natal, ao parto e ao recémnascido, sendo, portanto, passíveis de serem modificados. 
Neste estudo, a maioria dos óbitos (14 óbitos) foi relacionada a causas naturais, como crenças como a de que "passou um vento nele". Assim percebe-se um desconhecimento materno da causa do óbito infantil. Um das mulheres entrevistadas teve seus partos domiciliares, relacionou que os filhos que nasceram em casa foram os que morreram, porém, essa relação de fato só ocorreu com essa mulher.

Outros estudos também refletem sobre a temática da mortalidade infantil em contextos de pobreza, afirmando que o comportamento materno nesse contexto é mediado por construções culturais, que devem ser aprofundadas e compreendidas antes da interpretação dos motivos e ações no cuidado infantil (NATIONS; REBHUM;1988).

Hadad et al.,(2002), Goulart et al.,(2005) também criticam interpretações que culpabilizam a mãe pelo óbito infantil. O que é reforçado em outros estudos que assinalaram que, se existe uma "negligência" no Nordeste brasileiro, não é por parte das mães pobres, mas de um sistema sociopolítico e econômico injusto, que não cuida adequadamente dessas mulheres e de seus filhos. A exclusão do acesso aos serviços públicos, problemas de comunicação e descontinuidade de cuidados, entre outros fatores, e não uma atitude materna descuidadora, foram identificados como responsáveis pelas mortes das crianças (NATIONS; REBHUN; 1988).

É importante ressaltar que várias pesquisas indicam que em um contexto de altas taxas de adoecimento e óbito infantil, a promoção do aleitamento materno pode reduzir substancialmente esse quadro (MONTEIRO; REA; VICTORA, 1990; WHO, 2001; BETRÁN et al., 2001).

Alguns autores apontam, em seus estudos no Mundo e em comunidades pobres brasileiras, uma perda de afetividade dos indivíduos, um desligamento emocional entre a mãe-filhos (MANI et al., 2013; SCHEPER-HUGHES, 1992). Neste estudo foi ifentificado esse mesmo padrão comportamental de falta de afetividade em diversas situações do ciclo gravídico-puerperal dessas mulheres.

Essa percepção fica mais clara ao analisar os achados com base no modelo "Pesando riscos e benefícios" em que é possível perceber uma 
considerável diferença, isto porque no modelo, a mulher diante da gravidez confirmada, envolvida por todos os sentimentos que antecedem esse processo, começa a sentir a presença da criança, ter curiosidade sobre o feto, ter expectativas em relação à criança e sentir afeto por ela, o que de modo algum é referido pelas mulheres neste estudo. Diante de uma situação de pobreza, estar gravida significa mais um problema a ser enfrentado, e vem acompanhado com dor e incômodos, não havendo, dessa forma, falas de afetividade para com o feto ou criança. Esse quadro leva a uma reflexão sobre a possibilidade de um distanciamento dos padrões de afetividade característico desse momento de vida maternal e bem detalhado pelo modelo.

O estudo de Calvasina (2007), ao desenvolver o modelo popular de impressões maternas, enfatiza que as mães não acreditam que os seus problemas decorram do descuido, mas dos sofrimentos da vida: fome, "fastio", angústias emocionais, violência doméstica, falta de acesso às consultas pré-natais, entre outros. Chegando a referenciar uma ligação profunda entre a gestante e o feto. As narrativas do estudo revelam mães atentas e preocupadas com as possíveis influências insalubres na gestação, que poderiam prejudicar o bebê.

Para mulheres inseridas em um contexto de pobreza, existe a busca no atendimento de necessidades primárias de sobrevivência, e só depois de atendidas essas necessidades, é possível buscar outros patamares de satisfação, de outras necessidades, incluindo afetivas (MANI et al., 2013). Portanto, para esse grupo de mulheres, é necessário superar maiores dificuldades, como a fome, para que se possam perceber outros níveis de necessidades, incluindo as afetivas. Portanto, essas mulheres não são desprovidas de afetividade, existe um distanciamento desses sentimentos, pois suas atenções estão voltadas para outras demandas de sua vida. 


\subsection{AMAMENTAÇÃO: UM RECURSO CONTRA A FOME, NEM BOM, NEM RUIM - NORMAL}

\subsubsection{Um retrato da prática de amamentação}

Das $35(100 \%)$ mulheres, $32(91,4 \%)$ referem já ter amamentado todos os filhos por algum tempo, desde AME até AM, as demais amamentaram pelo menos um filho. Entre estas, 24 (68,5\%) referem já ter desmamado todos os filhos, cuja criança, com menor idade, estava com 30 meses, na época da entrevista. As demais, 11 (31,5 \%) ainda estavam amamentando, e as crianças tinham idade variável de quatro dias a três anos.

É importante ressaltar que entre as $11(31,5 \%)$ que estavam amamentando, $2(18,1 \%)$ mulheres mantinham o AME, sendo uma criança com quatro dias e outra com sete meses; 9 (81,8\%) estavam amamentando seus filhos, sendo possível caracterizar esta pratica como AMC sendo as crianças com idade de três meses a cinco anos, 2 (22,2\%) nutrizes referem que seus filhos já recebem complemento desde o nascimento, sendo 1 $(11,2 \%)$ de dois meses, já estava recebendo complemento há 30 dias. Conforme referência materna, 6 (66,6\%) mulheres, com filhos maiores de seis meses, amamentaram seus filhos em AME por pelo menos 6 meses. Assim, do total de mulheres, 20 (28,5\%) mantiveram, pelo menos um dos filhos em AME ou ainda mantinham à época da entrevista deste estudo.

Entre as $24(100 \%)$ mulheres que não mais amamentavam, 14 $(58,3 \%)$ referem que tiveram pelo menos uma experiência de amamentar seu filho até 6 meses de forma exclusiva, mas 25 (71,4 \%), introduziram leite de vaca ou outro alimento para um ou mais filhos. A Tabela 7 mostra que a prática da complementação alimentar, principalmente com outros leites não materno, ocorre de forma precoce entre essas nutrizes, sendo que apenas uma entre as que já haviam deixado de amamentar, teve todos seus filhos em AME. e $40(42,1 \%)$ foram amamentadas exclusivamente e 55 $(57,9 \%)$ receberam outros alimentos antes de seis meses.

A média de amamentação exclusiva, segundo a referência delas foi de três meses e a média de amamentação complementada de 22,3 meses. 
Tabela 7- Distribuição das mulheres moradoras da Comunidade Mangabeira, segundo quantidade de filhos vivos em AME até seis meses e os que tiveram a AMC antes dos seis meses, Arapiraca, 2013.

\begin{tabular}{c|c|c|c}
\hline $\begin{array}{c}\mathbf{N}^{\mathbf{0}} \text { de } \\
\text { Mulheres }\end{array}$ & $\begin{array}{c}\mathbf{N}^{\mathbf{0}} \text { de filhos vivos } \\
\text { por mulheres }\end{array}$ & $\begin{array}{c}\mathbf{N}^{\mathbf{0}} \text { de filhos em } \\
\text { AME até 6 meses }\end{array}$ & $\begin{array}{c}\mathbf{N .}^{\mathbf{0}} \text { de filhos em } \\
\text { AMC antes dos 6 } \\
\text { meses }\end{array}$ \\
\hline 2 & 1 & 1 & 1 \\
\hline 4 & 2 & 4 & 4 \\
\hline 5 & 3 & 6 & 18 \\
\hline 7 & 4 & 10 & 0 \\
\hline 1 & 5 & 5 & 2 \\
\hline 2 & 6 & 0 & 9 \\
\hline 1 & 7 & 5 & 9 \\
\hline 2 & 9 & 9 & \\
\hline
\end{tabular}

Assim, embora o tempo total de oferta do leite materno seja alto, chegando próximo dos 24 meses recomendados pela OMS, constata-se que o tempo em AME, para a maioria das crianças, é muito aquém do ideal, não passando de três meses, havendo a introdução precoce de outros alimentos, em especial, o gogó, uma mistura de leite de gado integral com farinha de mandioca fina (farinha nenê) que é tradicionalmente oferecido às crianças dessa região. Mas também, a oferta de alimentos sólidos que não segue obviamente uma dieta balanceada e de acordo com idade, mas a dieta de oportunidade, ou seja, a mãe oferta à criança os alimentos disponíveis em seu lar.

A prática de introdução precoce, antes dos seis meses, de outro leite é também encontrada em outros estudos no mundo e no Brasil. Estudo realizado no sul da Etiópia mostrou que 38,7\% dos entrevistados começou a dar alimentos complementares ou outros que não o leite materno (principalmente água, mingau e outras preparações à base de cereais semissólidos ) para seus filhos antes que eles chegassem aos seis meses de idade. Para metade dessas mães, a razão para a introdução de alimentos / 
bebidas muito cedo, foi a crença de que o leite materno não é suficiente para alimentar o lactente nessa idade (WONDAFRASH; AMSALU; WOLDIE, 2012).

No Brasil, a Pesquisa Nacional de Demografia e Saúde (PNDS, 2009), constatou que a mediana estimadora de aleitamento materno exclusivo foi de 2,2 meses, um pouco menor que os três meses que se encontrou entre os filhos de mulheres da Comunidade Mangabeira já em desmame. Já as medianas de aleitamento materno no Brasil, apesar do incremento observado de sete para catorze meses é bem inferior ao 22, 3 meses que o encontrado na Mangabeira (BRASIL, 2009)

Essa mesma pesquisa também demostra que no Brasil, as medianas de aleitamento materno exclusivo são relativamente homogêneas, segundo as macrorregiões do Brasil e características das mulheres. Para a maioria das situações, acima dos 1,1 meses da mediana de 1996, mas não ultrapassam os 2,6 meses. As medianas de duração do aleitamento materno são mais altas que a mediana nacional nas regiões Norte e Nordeste, entre os filhos (as) de mulheres de baixa escolaridade, o que confirma os nossos achados, mesmo analisando um grupo pequeno de crianças.

Os significados de amamentar para as mulheres, que sobrevivem da reciclagem, envolvem três temas, são estes: Tema 1: Determinada a amamentar: do saber à necessidade; Tema 2: Prática de amamentar: cuidado familiar e coletivo. Tema 3: Fragilidades na valorização da amamentação, que de forma estruturada, revelam todo o processo vivenciado e definem o caminho dessas mulheres ao amamentarem. Suas relações sociais e culturais em uma de vida na pobreza, e como trabalhadoras da rede de reciclagem de lixo.

Apesar de sua experiência cotidiana de privações, a amamentação não representa um recurso exclusivo e único de alimentação da criança. $\mathrm{O}$ significado de sobrevivência que a amamentação assume, na perspectiva de algumas mulheres, pode ser transitório e está sob avaliação das diferentes condições maternas, de estar disponível para estas práticas, avaliado com dados objetivos ou subjetivos. As condições objetivas de vida, como a privação de alimento ou a necessidade de se ausentar para o trabalho, sentir- 
se fraca e incapaz para amamentar, mas em alguns casos sente-se como o recurso para a sobrevivência do filho, são elementos que transitam na vivência dessas mulheres e vão assumindo importância e valor, à medida que se apresentam, permanecem ou se modificam. Tornam o processo de amamentação ora vital para a criança e fundamental para a família, ora substituível ou indesejado, pela mulher.

A amamentação é respeitada como um processo materno natural, em que, mesmo não estando plenamente satisfeita, por conta do aumento da demanda de atribuições, ela precisa de alguma forma conduzir, para garantir a sobrevivência de seus filhos. Um processo encarado como parte necessária e previsível em sua experiência da maternidade. Os Temas que retratam tal experiência estão apresentados no Quadro 1. 
Quadro 1 - Temas e ideias sínteses dos DSC - Amamentação: Um recurso contra a fome, nem bom, nem ruim - normal

\begin{tabular}{|l|}
\hline 4.4.1 TEMA 1 - Determinada a amamentar: do saber à necessidade \\
\hline DSC. 26 Sei de casa como amamentar \\
\hline DSC. 27 Eu botei na cabeça e dei de mama \\
\hline DSC. 28 Eu me sinto mãe, e ser mãe é uma coisa ótima \\
\hline DSC. 29. Menino que mama é mais saudável \\
\hline DSC. 30 Amamentar também é bom para mãe \\
\hline DSC. 31 A criança não aceita outro alimento \\
\hline DSC. 32 Sofri pressão do meu companheiro para amamentar \\
\hline DSC. 33 Se Deus me deu o leite eu não posso negar para a criança \\
\hline DSC. 34 Mulher como sustento do filho \\
\hline 4.4.2 TEMA 2 - Prática de amamentar: cuidado familiar e coletivo \\
\hline DSC. 35 Amamento exclusivamente \\
\hline DSC. 36 Sigo amamentando e dando papa desde o nascimento \\
\hline DSC. 37 Dei de mamar aos filhos do povo \\
\hline 4.4.3 TEMA 3 - Fragilidades na valorização da amamentação \\
\hline DSC. 38 Amamento com peitos feridos \\
\hline DSC. 39 Nunca gostei de amamentar, por isso dou gogó \\
\hline DSC. 40 Meu leite não sustenta nem satisfaz meu filho \\
\hline DSC. 41 A criança não quer mamar \\
\hline DSC. 42 Deixei de amamentar para trabalhar \\
\hline DSC. 43 Amamento algumas vezes na creche \\
\hline DSC. 44 As crenças e crendices sobre a amamentação \\
\hline DSC. 45 Qualquer criança pode adoecer mamando ou não \\
\hline DSC. 46 Amamentar tem o lado bom e o lado ruim \\
\hline
\end{tabular}




\subsubsection{TEMA 1 - Determinada a amamentar: do saber à necessidade}

Os elementos, que levam essas mulheres a amamentar, são percebidos pela maneira como ela se vê diante da demanda da alimentação de seu filho e de como ela percebe a amamentação em seu meio social. Ou seja, a percepção gerada por meio da interação com si mesmas, com as pessoas ao seu redor e a criança faz com que essas mulheres construam os mais diversos sentimentos que as levam a uma determinação do amamentar.

Esses sentimentos podem ser vivenciados de forma positiva ao entender a dinâmica da amamentação com base em seus conhecimentos e dos profissionais de saúde, de se perceber mãe ao amamentar, e de compreender os benefícios da amamentação parar a criança e para si mesma, compreendendo a amamentação como um processo natural e possível ou muito necessario. Nessa mesma linha de pensamento, a amamentação é valorizada, quando representa um recurso para suprir uma necessidade essencial de "matar a fome".

Portanto, alguns outros elementos geram sentimentos contraditórios, porém são determinantes para que essa mulher amamente. Esses motivos fazem parte do contexto social em que essas mulheres estão inseridas e geram a percepção da necessidade de amamentar, por conta de sua vida de pobreza. Dentre esses motivos estão a pressão do filho e do marido e a amamentação motivada pela falta de acesso a outros alimentos que fazem com que essas mulheres se percebem como o próprio sustento de seus filhos. Os DSC que compõem esse tema mostram esta construção. 
Quadro 2 - Temas 1: Determinada a amamentar: do saber à necessidade

DSC. 26 Sei de casa como amamentar

DSC. 27 Eu botei na cabeça e dei de mamá

DSC. 28 Eu me sinto mãe, e ser mãe é uma coisa ótima

DSC. 29. Menino que mama é mais saudável

DSC. 30 Amamentar também é bom para a mãe

DSC. 31 A criança não aceita outro alimento

DSC. 32 Sofri pressão do meu companheiro para amamentar

DSC. 33 Se Deus me deu o leite, eu não posso negar para a criança

DSC. 34 Mulher como sustento do filho

Assim no DSC. 26, as mulheres deste estudo relatam que a experiência adquirida no seio familiar, quanto à prática de amamentação, parece significar um tipo de aprendizado diferente do que seria uma orientação técnica e profissional, pois toda a observação das vivências femininas em seu entorno e apoio de familiares não representa necessariamente orientação específica sobre como aprender a amamentar, mas significa uma construção cotidiana que leva a mulher a adquirir segurança e uma naturalidade para o exercício da prática, se esta é vista como inerente ao processo de ser mãe.

\section{DSC. 26 Sei de casa como amamentar}

Eu amentava mesmo, agora orientação nunca tive. Minha mãe ensinou como dar de mamar, colocar o peito na boca do nenê e ajeitar para não sufocar. A minha vó vivia comigo dentro de casa e ensinou como é que botava o peito na boca dele e assim fui criando a minha filha $e$ aprendi a dar de mamar aos meus filhos. A gente já vem sabendo de casa, que quando você tem um filho, você tem que amamentar, ninguém me orientou sobre isso, já era uma coisa que eu sabia, eu já estudava, tinha livro e tudo. Eu também sempre fui curiosa, quando via as outras mães conversando, ficava sempre de olho. E o povo também dá dica, dizendo 
que é bom amamentar até os seis meses, aí, o menino acostumou, acostumava mesmo. Aí, eu achava bom amamentar, amamentava.

As mulheres deste estudo, de alguma forma, demonstram construir uma disposição prévia em sua vivência, que pode ser uma determinante na definição dos rumos a ser seguidos em seu processo de amamentação. Esse posicionamento é tomado antes mesmo do nascimento de seu filho, pois é derivado de suas crenças, conhecimentos teóricos e práticos sobre o leite materno, que são adquiridos no seu meio social, principalmente familiar. Portanto, o significado de aprender a amamentar representa as oportunidades que lhes são oferecidas ao longo de sua vida, de conviver com mulheres que valorizam a amamentação.

As informações recebidas por essas mulheres, no meio social em que vivem, formam seu conceito sobre o processo de amamentar. Nesse sentido, algumas delas parecem desenvolver uma atitude autônoma na gerência do seu conhecimento sobre o aleitamento materno, assunto que afirmam dominar com base em sua experiência, mesmo sem orientações recebidas de profissionais de saúde. Estudo de Shimoda e Silva (2010) também compartilha desse mesmo resultado, pois a mulher ao apoderar-se desses conhecimentos conquista uma "autonomia" para manutenção da amamentação.

Barreira e Machado (2004) também consideram a família como o primeiro e mais importante grupo que define os comportamentos apresentados pelos indivíduos, compreendendo que as transformações sociais afetam a maneira como as pessoas assumem seus papéis no meio social em que estão inseridas.

Além disso, outros autores afirmam que quanto mais cedo a importância da amamentação for internalizado, mais favorável e positiva esta prática torna-se para o indivíduo. Assim, é essencial iniciar a promoção da amamentação ainda durante a infância e a escola é o principal ambiente institucional que pode favorecer esse processo (LINHARES et al., 2013; GALVÃO; SILVA; 2012).

Por outro lado, para algumas mulheres, a construção do seu conhecimento e a percepção sobre o processo de amamentação tem relação 
com o aprendizado, advindo dos profissionais de saúde, ao mesmo tempo em que percebem que esse conhecimento poderia ter sido construído também fora do seio família, como pode ser visto no DSC abaixo:

\section{DSC. 27 Eu botei na cabeça e dei de mamar}

Eu amamentei porque a doutora e a enfermeira do posto diziam que era bom para a saúde deles, aí, quando eu tive meus filhos, ela sempre dizia que eu desse de mamar, porque é bom que eles não fiquem desnutridos e no futuro vão ficar saudáveis, $e$ "eu botei na cabeça e dei". Mas só as enfermeiras, porque minha mãe não me ensinava essas coisas, ela é do tempo antigo, tinha vergonha de ensinar, por isso aprendi lá no hospital.

De fato, os profissionais de saúde desempenham um importante papel de incentivo ao aleitamento materno, mas é uma decisão tomada pela mãe, e confirmado no DSC. 27 pela fala "eu botei na cabeça e dei". O contato com os profissionais, da mesma forma que as influências vividas em seu contexto social podem construir uma determinação da mulher em amamentar enfatizando os aspectos voltados para a saúde da criança, o que significa uma motivação também importante para a decisão e manutenção do aleitamento materno.

Evidências de vários países indicam que a melhorias nos indicadores de aleitamento materno é possível com ações efetivas, que enfatizem a capacitação dos profissionais de saúde, para o aconselhamento de mulheres sobre as práticas de aleitamento materno (UNITED NATION CHILDEN'S FUND, 2009). Portanto, esse adequado suporte tem sido um fator importante para a questão da duração do aleitamento materno (MORAN et al., 2005). Os profissionais de saúde ao prestarem suporte de forma positiva, com conhecimentos apropriados por suas habilidades, são primordiais no incentivo e na condução das práticas de aleitamento materno (CLIFFORD; MCINTYRE; 2008). E as mulheres reconhecem a importância da orientação dos profissionais de saúde, como estímulo, para que possam ter maior confiança e êxito na amamentação (SHIMODA; SILVA, 2010). 
Outro aspecto interessante, que pode ser observado no DSC. 28, é que, ao exercer a prática de amamentar, a mulher consegue conciliar suas responsabilidades com a criança e a realização pessoal, valorizando sua própria importância na vida da criança por representar na amamentação a sobrevivência desse filho, seja ela física ou afetiva.

DSC. 28 Eu me sinto mãe, e ser mãe é uma coisa ótima

Amamentar é uma coisa muito boa, é tudo de bom para criança. A primeira coisa da vida é essa, para cuidar, dar carinho, amar, não é só ser mãe e pronto. Eu acho ótimo e gosto de dar de mamar. Eu me sinto mãe e ser mãe é uma coisa ótima. Quando se nasce um filho é uma vitória ser mãe. Por isso que amamentar é importante, porque é o meio de sobrevivência daquele recém- nascido.

A amamentação parece representar uma possibilidade de conciliação das responsabilidades atribuídas ao papel materno e da realização feminina. Por um lado, há uma demonstração de percepção de que o papel da mulher não se restringe ao de parir, mas é preciso agregar sentimentos, cuidados e afeto para a qualificação do ser mãe. Outros estudos reforçam a existência da relação da amamentação com o papel materno, assim, a amamentação constitui uma expressão do amor materno (CARRASCOZA, 2011). Arantes (1995) chama atenção para as falas das mulheres sobre amamentação, de fato tem essa relação direta com o Amor Materno, mas, essa mesma autora descreve a importância da amamentação para o desenvolvimento de uma maior ligação afetiva entre mãe-filho (ARANTES,1995). Dessa forma, essa ligação de afetividade entre mãe e filho, proporcionada pela amamentação, pode favorecer as mulheres deste estudo o desenvolvimento de laços afetivos, necessários à mãe e à criança.

Pelo que expressa no DSC 29, as mulheres desse estudo percebem a amamentação como um ato de cuidado para com a criança, que parece ser uma forte motivação para a prática de amamentar. Também, alimentar a criança e proporcionar meios para seu desenvolvimento saudável, representa um ato de cuidado, atribuído à mãe, e que depende de sua decisão ou intenção. 
DSC. 29. Menino que mama é mais saudável

A amamentação serve para o bem-estar da criança. $O$ menino que mama é mais saudável e bem cuidado.Meus filhos ficavam satisfeitos, por isso que eu pretendo amamentar por muito tempo. Esses meus filhos nunca adoeciam, crianças são muito enjoadas quando estão nascendo os dentes, porque fica sem querer comer. Então para mim é bom, pois já estou amamentando e ainda ajuda aos dentes a crescerem saudáveis. Eu trazia restos de comida do lixão e eles comiam e nunca tiveram nada, isso porque mamaram. Eles comiam qualquer coisa e nunca tinham nada. Além disso, o leite tem anticorpos que protegem a criança de muitas coisas, de muitas doenças, então a mama é muito importante. A tendência é aquela criança que não mama, ficar mais doente, o meu sobrinho só mamou 18 dias e hoje ele é um menino doente, ficava fraco e tinha que ir para hospital para tomar soro. Criança sem mamar fica mais triste, sei lá, fica mais estranha, eu sentia que ia ter problemas.

Para construir essa percepção positiva em relação à amamentação, um dos aspectos levados em consideração pelas mulheres é o resultado de crianças sadias que foram amamentadas, e mesmo quando submetidas à intensa agressão ambiental demonstram resistência e resiliência. A amamentação, segundo observação das mulheres, afeta também o estado emocional da criança.

Dessa forma, amamentar significa para algumas dessas mulheres manter seus filhos saudáveis e sem adoecer, mesmo quando são expostos a situações que podem levar ao adoecimento, como consumir alimentos oriundos do lixão. A amamentação é interpretada como protetora da saúde de seus filhos, como se observa no DSC 29.

Vários outros estudos demostram que a percepção materna, a respeito dos benefícios da amamentação para seus filhos, e a valorização desses benefícios, é uma forma de justificar a decisão das mulheres em amamentar (SILVA, 1997; BENEDETT, 2013). Outra pesquisa, só continua a confirmar essa relação, que as mães observam empiricamente, como no estudo de Ruel e Menon (2002) que, ao análisarem um conjunto de dados de vários países latino-americanos, demonstraram que o aleitamento materno e 
práticas de alimentação complementar apropriadas, foram associadas positivamente ao crescimento das crianças na maioria dos países estudados. Vários estudos no mundo, realizados em países desenvolvidos e em desenvolvimento, apontam os ganhos do aleitamento materno sobre as habilidades cognitivas e o desempenho escolar em comparação a bebês alimentados com outros leites (QUINN et al., 2001; HORWOOD et al., 2001; ODDY et al., 2004; MICHAELSEN et al., 2003).

Portanto, com base nos achados do deste estudo e as informações de outras pesquisas é possível constatar que no contexto de pobreza, a possibilidade de reversão de deficits cognitivos já problematizados anteriormente, por meio da amamentação podem de fato trazer grandes benefícios na reversão do quadro de iniquidades a que está submetida essa comunidade.

Algumas dessas mulheres avaliam constantemente as vantagens de amamentar como forma de justificar sua escolha, como, ter uma anatomia mamária própria e até privilegiada para amamentação, que a favorece diante de tantas outras mulheres do seu meio social que tiveram seus seios feridos, como pode ser visto no DSC. 30.

DSC. 30 Amamentar também é bom para mãe

Quando os peitos enchem e ela mama, dá um alívio e é bom, quando ela vai mamando, vai aliviando. Também é bom, pois, não dá problema de câncer, nem nada nos peitos e os meus seios nunca feriram, acho que é por conta do bico do peito.

Vários outros processos não são controlados pela mulher, como suas mamas estarem cheias, por isso, quando elas amamentam sentem alívio físico, que chega a ser prazeroso. Outra vantagem internalizada por essas mulheres é o fato amplamente difundido pelos profissionais de saúde que a amamentação protege a mulher contra as doenças na mama, incluindo o câncer. Portanto, são esses elementos significativos que interpretados definem o papel positivo na adesão à amamentação que garante ganhos para crianças e mães desse grupo. 
Todos esses benefícios, agregados às vantagens de amamentar para os filhos, já descritas, só reafirmam a valoração da amamentação e que motivam essas mulheres a amamentarem. Segundo Silva (1997, p. 242), “A mulher quando assim vivencia o amamentar, pode estar aquilatando apenas um dos símbolos como benefício ou o seu conjunto. Assim, as prioridades estabelecidas pela mulher nesse processo e o valor atribuído a cada risco ou beneficio é que dá o tom a essa sinfonia [...].”

Porém, em alguns casos, possa não estar motivada ou disposta a amamentar, a mulher se vê na condição de manter a amamentação mediante sua interpretação das manifestações de comportamento da criança que pode demonstrar ter dificuldades de aceitar outros alimentos em especial, tipos de leite não humano. Esse comportamento infantil pode condicionar as atitudes maternas em uma sequência de obrigatoriedades para manter a produção láctea, e consequentemente a amamentação de seu filho (DSC31).

\section{DSC. 31 A criança não aceita outro alimento}

Se eu não amamentasse, estaria trabalhando até hoje. Eu queria trabalhar e tentava dar outros alimentos, com 15 dias, fiz chá de hortelã miúda, fiz o gogó de leite puro e fui dar e ela não quis não, quando eu espremia o gogó na boca dela, ela botava para fora, é como se o intestino dela não aceitasse. Ela também não chupava o bico da mamadeira e só se contentava com o peito. $E$ eu continuo dando de mamar, mesmo depois de meu filho grande e ele continua sem querer pegar nada, não chupa chupeta e o gogó começou a tomar agora, porque foi para creche, foi só por isso que está comendo. Mas em casa não come nada, comida para ele é bolacha, pão, Danone, banana, mas leite não quer, é só besteira. Se você botar uma comida para ele comer, ele come uma colher e joga o resto, uma carne só quando tem vontade de comer ou quando ele leva uma tapa. Só quer peito, de instante em instante tenho que estar bebendo suco, comendo alguma coisa para aguentar.

Assim, percebe-se que há uma atenção aos comportamentos da criança e uma dificuldade em saber lidar com a introdução de outros alimentos, de forma oportuna ou não, mantendo a amamentação como sendo de escolha 
da criança e obrigação materna por não se ver com outra opção de alimentação saudável do filho. $\quad \mathrm{O}$ retorno ao trabalho é adiado por conta da amamentação, criando na mulher expectativas conflitantes por precisarem amamentar o seu filho.

Outros estudos corroboram com esta pesquisa, com a identificação de conflitos exercidos entre o retorno ao trabalho e a amamentação. Assim, como no modelo "Pesando Riscos e Benefícios" neste, a mãe justifica a manutenção da amamentação da criança que não aceita outros alimentos, ou seja, a nutriz estabelece suas prioridades e, mediante elas, programa suas ações de manutenção do aleitamento materno ou desmame (SILVA, 1997).

Arakati (2008) também destaca que a mulher, durante a pratica da amamentação, percebe que está fazendo sua responsabilidade e seu papel materno. Identificando que, em algumas mulheres, mesmo tendo a necessidade em contribuir com renda familiar, fazem a opção de não retornar ao trabalho, priorizando amamentar a criança (SILVA, 1997; SHIMODA; SILVA, 2010).

Segundo o DSC 32, os companheiros dessas mulheres têm papel importante na tomada de decisão delas na condução do processo de amamentação, transparecendo que isso é feito de forma autoritária.

DSC. 32 Sofri pressão do meu companheiro para amamentar

Meu marido acha bom e, ao mesmo tempo, acha ruim eu amamentar, porque eu ainda ajudava a ele no trabalho. Mesmo assim, eu dei de mamar com medo dele me deixar, só não tirei o peito dela, porque quando ela era menor, ele falou se tirasse me deixava. E agora com ela grande, já era para ter deixado de mamar, mas eu não pretendo tirar à força a mama dela, às vezes eu falo assim: eu não vou dar de mamar e lá vem ela com o pai dela e ele diz: eu nem quero saber, se ela quiser você vai dar. Mas não tem condições, com uma criança grande e mamando! E ele ainda pergunta: por que ela não quer mamar? $E$ dizia, olha o desperdício de leite e ainda tem que comprar leite, tendo leite.

Embora a amamentação possa representar a ausência da mulher no ambiente de trabalho e parceria na produção familiar, também pode 
representar benefícios que superam essa deficiência. A mulher tende a ceder, mesmo que a amamentação não seja propriamente sua opção ou desejo, mas busca garantir a presença do parceiro no lar e a manutenção de sua relação, se esta é a vontade e convicção masculina.

Em um contexto de dificuldades de acesso a alimentos, ter a disponibilidade do leite materno é interpretado pelo companheiro como uma possibilidade de poupar o orçamento familiar, um menor gasto financeiro.

As pesquisas que abordam a dinâmica das relações conjugais, durante o processo de amamentação, afirmam que a participação do companheiro foi um fator que favoreceu o aleitamento materno, pois o companheiro é reconhecido como um apoio e incentivo para o processo de amamentação, quando compartilha as responsabilidades de cuidados com os filhos. A mulher compreende que o desenvolvimento das ações compartilhadas pelo casal para com os filhos faz parte do "compromisso matrimonial" (LINHARES et al., 2013; DEMÉTRIO, et al., 2013). Para Bosi e Machado (2005) este comportamento dá ao pai a oportunidade de cuidar da criança, encorajando-o a sentir-se a amamentação não apenas como algo exclusivo da mãe, mas também como a partilha de responsabilidades a serem assumidas pelo casal em seu meio familiar.

Mas no contexto do deste estudo, a ação do companheiro de fato favorece ao aleitamento materno, mas, não é possível perceber que a pressão, que esses companheiros exercem sobre suas mulheres para amamentar, possa ser identificada como uma relação positiva e de companheirismo. Em alguns momentos elas tendem a interpretar essa atenção masculina, voltada à amamentação, como uma forma desse homem se importar com o que acontece no seu lar. Mas as questões que envolvem as dificuldades de sobrevivência são as que parecem determinar esse comportamento masculino, diante da amamentação.

No DSC. 33, a mulher, com base na sua interpretação, avalia o volume de leite que está produzindo e qualifica-o no comportamento da criança. Assim, se seu filho aceita bem a mama, é julgado por sua mãe como bem alimentado. 
DSC.33 Se Deus me deu o leite eu não posso negar para a criança

Eu já tinha leite antes mesmo dela nascer, meu peito já tinha leite e estava tão cheio que derramavam. Depois que ela nasceu, começou sair mais leite. O leite sustentava, porque senão eles não mamavam até hoje. Por isso que eu achava que meu leite era normal, tanto que ele deixou de mamar por ele mesmo. Eu já estava acostumada e pensava assim, eu tomo muito liquido e chega muito leite e quando eles começavam a puxar é que chegava mais. Logo no começo é que era muito, eu era bem leiteira, chega a vir tanto leite que começava a derramar e pedrou, que chega a me dar dor de cabeça, eu boto uma fralda que fica derramando, e não faço nada, eu dou o peito, aí seca (volta ao normal) e sustenta. E já que eu tenho leite, não adiantava pegar o leite que eu tinha e botar no fogo para secar. E ter uma coisa, que pode dar e não dar é muito complicado, porque eu não sei ter uma coisa e uma pessoa tá precisando e eu não dar, se eu posso dar e eu estou dando para o meu filho, eu negar isso para ele, eu me sentiria muito mal de está escondendo aquele leite, se a criança queria, então eu dava. Deus me deu o líquido, eu tinha que dar os peitos cheios que derramava, eu dizia: Deus me deu, eu não posso negar, mamem, meus filhos, até não querer mais.

Outro aspecto que favorece a amamentação é que algumas mulheres, ao perceberem e avaliarem positivamente sua produção láctea, sentem-se motivadas a amamentar e, nessa dinâmica, decidem que não podem negar ao seu filho o que têm de disponível para alimentá-lo, seu leite. Essa mesma percepção também é compartilhada por outras mulheres que vivenciam a prática da amamentação, em outros contextos, portanto, esses achados confirmam que para a mulher ter boa produção de leite implica em ter condições para satisfazer a necessidade de boa alimentação do seu filho (SILVA, 1997; SHIMODA; SILVA; 2010). Assim, segundo Nakano (2003), é preciso considerar as próprias condições de "ter leite" para poder amamentar.

A mulher também percebe e avalia, por meio da sua experiência, não ter controle sobre a produção de leite, mas que, com o tempo, pode ser estimulada com aumento da ingesta hídrica e da sucção da criança à mama. 
Ou seja, como também encontrado em outros estudos, a mulher percebe aumento da produção de leite após a adoção de medidas, como o estimulo da sucção da criança ao seio materno e o aumento da ingesta de líquidos (SHIMODA; SILVA, 2010).

Outro aspecto interessante, relatado pelas mulheres deste estudo, é que, mesmo quando a maior quantidade de leite gera problemas, como ingurgitamentos mamários, estes podem ser resolvidos no curso da amamentação, não se mostrando como dificuldade para o prosseguimento da prática.

Para algumas dessas mães, amamentar significa um processo natural, possibilitado por Deus, tendo nela a forma de sustento de seu filho. Em uma vivência de escassez alimentar, não amamentar seu filho, tendo leite, pode representar um desperdício que vai de encontro às suas crenças, de um processo natural. Sendo também, a interrupção da amamentação, por decisão materna ou manobras para diminuição da produção do leite, uma forma de negação à criança de algo que pode ser oferecido e está disponível para ser oferecido para o filho.

A responsabilidade natural de a mãe amamentar é referido em alguns estudos, que analisam a mulher como fisiologicamente responsável pela produção de leite, e assim, essa mulher se sente naturalmente responsável pela prática de aleitamento materno (SHIMODA, SILVA, 2010).

Simbolicamente, a amamentação tem se mostrado, na fala dessas mulheres, como uma estratégia de sobrevivência para a criança tanto na superação da fome, como na percepção materna de que a amamentação é uma oportunidade de saúde, resistência física e imunidade para a criança, além de suas potencialidades afetivas e de segurança emocional para ambos.

DSC. 34 Mulher como sustento do filho

Quando não tem nada para botar na boca do meu filho pequeno, o jeito sou eu, o peito. Eles mamavam e eu dizia, enquanto eles estão mamando, que eu puder dar, eu não vou quebrar a cabeça, enquanto eu pudesse sustentar, eu sustentava. Eu dava graças a Deus, pois não tivesse dado de mamar eles tinham morrido, porque não tinha comida, foi uma 
bênção da mão de Deus. Amamentar ajuda, pois mesmo que eu tivesse tremendo e caindo de fome, eu sabia que os peitos estavam cheios $e$ alimentando meus filhos, mesmo água de peito, que não sustenta mas alimentava, alimentava e muito. Quando eu tinha dinheiro, eu comprava leite de gado e deixava para noite porque é mais forte, eu sustentava o dia com a mama e a noite com papa de hortelã miúda. Quando tem um pão, uma bolacha, ela come, senão, ela dorme com um peito na boca, não tira para nada.

Conforme o DSC. 34, amamentar parece assumir um significado extremo como meio de suprir as necessidades do lactente, não como uma prática simplesmente adotada, mas aqui, nesse caso, sugerindo que a mulher reconhece ser ela, a fonte alimentar do filho. Representa a doação direta na qual a mulher se reconhece como o próprio recurso de sobrevivência da criança. A amamentação, ou capacidade de produzir leite, é provida por algo transcendente e por meio da qual, ela, a mãe, se projeta como instrumento de salvação do filho, em um quadro social onde a criança pode perecer pela fome.

A amamentação em si, tem um valor relativo, quando pode ser substituída por outro alimento, quando este existe, ou pode ser combinado à outra fonte alimentar para dar mais sustento e saciedade à criança. É um recurso, que concilia o peito, o leite, a amamentação e a própria mulher, que pode ser compreendido quando ela enfatiza, " o jeito sou eu, o peito".

Em qualquer condição de saúde ou de disposição, a mulher se vê capaz de produzir o alimento da criança, considerando assim, que assegura, mesmo com a possibilidade de interpretação de leite fraco ou de "água de peito", um alimento ou a esperança da saciedade.

Shimoda e Silva (2010) identificaram em seu estudo que ter uma boa alimentação está entre os elementos necessários para favorecer o grupo de mulheres a ter boas condições de vida e assim poder amamentar exclusivamente até seis meses. Isso porque a mulher tem a noção da passagem de nutrientes de seu organismo para compor o seu leite materno. Silva (1997) também afirma que a mulher acredita que para produzir um leite de boa qualidade, ela necessita de condições mínimas de saúde e entre 
elas uma boa nutrição. Além disso, na vivência de insegurança alimentar, qualquer alimento é mais uma oportunidade de distanciar-se da fome, então poder dar outro alimento ao seu filho é tão importante quanto amamentar. É com base nessa interpretação, que para algumas mulheres a amamentação perde seus atributos de exclusividade até seis meses de idade e passa a ser, junto a outros alimentos, mais uma estratégia de sobrevivência, para afastar a fome de seus filhos.

Essas mulheres, em seus DSC, ao descreverem os momentos de maiores dificuldades, atrelados à vivencia de fome, buscam conforto na fé em Deus, e a amamentação, além de significar o afastamento da fome para seu filho, ainda significa ter sido "uma bênção da mão de Deus".

\subsubsection{TEMA 2 - Prática de amamentar: cuidado materno, familiar e coletivo}

Nessa temática, os DSC expressam a necessidade das mulheres manterem seus filhos bem alimentados, e a amamentação, em sua visão, é a melhor forma para isso. Mas para manter a amamentação de forma exclusiva se faz necessário muita dedicação e disponibilidade materna e ainda e necessidade de agir de forma autônoma diante de seus familiares para conseguir êxito na pratica da amamentação.

Para aquelas mulheres que se percebem sem condições de conciliar suas demandas de vida e as de seus filhos com o processo de amamentação exclusiva, decidem por oferecer outros alimentos, e junto continuam a amamentação. Ou seja, quando a demanda dela e da criança passa a não ser atendida, o processo de amamentação exclusiva está em risco, mas pode ser mantida a amamentação, na medida das possibilidade e desejo materno, e mesmo infantil e também com a participação e colaboração de outras nutrizes, caracterizando a pratica do aleitamento cruzado, significado de solidariedade entre as mães da comunidade. 
Quadro 3 - Temas 2: Prática de amamentar: cuidado familiar e coletivo DSC. 35 Amamento exclusivamente

DSC. 36 Sigo amamentando e dando papa desde o nascimento

DSC. 37 Dei de mamar aos filhos do povo

A vivência do processo de amamentação é iniciada ainda na maternidade, e demostra a superação dos problemas comuns, possíveis de ser detectados nos momentos iniciais de interação entre mãe e filho, exibindo, nas falas dessas mulheres, uma dedicação inicial que se prolonga nos meses seguintes, com a disponibilidade para praticar a amamentação exclusiva (DSC. 35).

\section{DSC. 35 Amamento exclusivamente}

Meus filhos mamaram muito tempo, eles mamaram bem, quando eram novinhos, não é para dar gogó, não é pra dar nada, só mama. Assim que ela nasceu, no hospital, a enfermeira limpou e botou ela para mamar, lá na mesa mesmo. Embora não tivesse conseguindo pegar, eu já dei de mamar lá na maternidade. Depois, quando vinha da maternidade, dava de mamar a eles direitinho, não tinha hora, eu nunca marquei hora para dar de mamar. Quando eu via que eles queriam mamar, eu dava, que nem ela, quando ela quer, eu paro o que estou fazendo e vou dar. Pode ser o dia todo, quando ela quer. Mama de instante em instante, quando chora, passa é a noite toda mamando. Da minha primeira filha, ninguém se metia, ninguém pegava que eu não deixava, por isso ela nunca tomou gogó, nunca tomou leite. Quando começava, assim mais velhinho que eu via que dava para dar comida eu dava, mas após o seis meses, foi quando eu comecei a trabalhar e eu vinha em casa na hora de dar de mamá. Mas eles já estavam mais durinhos e eles comiam comidinha de panela e eu dava de mamar e ia trabalhar. Eles nunca pegaram chupeta, nem gogó, até hoje é só comida e peito mesmo. Todos mamaram até depois de grande. 
A importância da dedicação materna também é apontada em outras pesquisas, como uma importante condição materna de entrega total à satisfação das necessidades das crianças, durante $o$ processo de amamentação. Um estado de prontidão e vigilância constante, em um movimento que envolve a percepção de sinais que, garantam o bem-estar do filho por meio da amamentação (SHIMODA; SILVA; 2010; NAKANO, 2003)

Para as mulheres deste estudo, conseguir manter a amamentação dos filhos e, ainda assim, organizar seu tempo com o trabalho. A sensação de fazer o que é o correto, ou seja, amamentar exclusivamente e seguir amamentando, faz com que ela pretenda conduzir a amamentação de forma incondicional, não aceitando outras ideias, como o oferecimento de bicos e mamadeiras, pois vão de encontro à sensação de dever cumprido no cuidado com seus filhos. Benedett (2013) destaca em seu trabalho que, as mulheres se sentem reconhecidas por amamentar. E esses sentimentos fortalecem o significado positivo da amamentação.

Nesse caso, a introdução de outros alimentos pode sofrer a interferência de outras pessoas e por essa razão, a determinação materna demonstra, além da disponibilidade de amamentar, um domínio do contexto, em que ela é o agente decisório do que e quando introduzir na dieta da criança, sem a anuência de interferência de outras pessoas.

Müller e Silva (2009), apesar de constatar que a mulher necessita do apoio constante de familiares e de membros de sua comunidade ou contexto social, estão de acordo com Silva (1997), de que uma das maiores influências podem ser impostas à nutriz pelos familiares que a auxiliam no cuidado com a criança. Nesse sentido, o DSC. 35, mostra que a mulher percebe necessitar ter autonomia e exercer um papel definido na sua relação com os demais, para não se deixar influenciar ou dominar pelas opiniões ou iniciativas voluntárias de terceiros, no que diz respeito a mudanças de seus planos de amamentação.

Já o DSC. 36, algumas dessas mulheres avaliam que em sua vivência de pobreza e como trabalhadoras, não é possível utilizar a amamentação 
como única fonte de alimento de seus filhos, mesmo que logo após o nascimento.

DSC. 36 Sigo amamentando e dando papa desde o nascimento

Meus meninos quando nasciam sempre dava de mamar e já dava papa de farinha de mandioca. No mesmo dia que ela nasceu, eu dei papa. Eu dava era farinha nenê com leite de gado e dava o peito. A comida eu dava só duas vezes ao dia, de manhã e a noite, porque o peito era cheio demais e eu não aguentava e sustentava assim, em comida e em peito e assim foi com todos. Só na mama não sustentava de jeito nenhum e eles não se contentava só com o peito tinha que comer, mas mesmo assim eu nunca deixava de dar o peito. Eles tinham muitas cólicas, aí eu dava chuquinha e dona de casa não pode só dar de mamá, quando eu trabalhava dava gogo a ele e quando eu chegava dava de mamar à noite todinha. Eu marcava o tempo de dar a comida e tempo de dar o gogó, aí, o resto do dia é só peito. Os meus meninos continuaram mamando por muitos anos.

O aleitamento exclusivo não depende apenas do volume de leite que a mulher percebe produzir. O DSC. 36, mostra que mesmo tendo leite em grande quantidade, aparentemente interpretada pelo volume da mama percebido pela mulher, outros fatores, como a necessidade de cuidados de casa e de trabalho, desconfortos apresentados pela criança, e ainda, pela avaliação de que o leite materno apenas, não sustenta a criança, a introdução de outros alimentos ou leites não humano é praticado precocemente por algumas mulheres.

A não exclusividade do leite humano não representa necessariamente uma negação de seu valor ou de sua importância, mas uma possibilidade de conciliação na satisfação das necessidades de saciedade e alimentação da criança e das atividades e repouso materno.

A depender das experiências anteriores ou de seu entorno, a introdução de outros alimentos já é pensada e planejada, desde o início dos cuidados com o recém-nascido, tornando-se uma forma habitual de cuidado alimentar infantil, para essas mulheres com a sua prole. Silva (1997) aponta que embora algumas mulheres desejem amamentar, já planejam o tempo de 
amamentação, associado a esse tempo, está a ideia de complementação com outro leite.

DSC.37 Dei de mamar aos filhos do povo

Eu amamentava minha filha e ainda amamentei um irmão meu até uns seis meses. Também amamentei a menina da minha irmã, eu dava de mamar as duas e dei muito aos filhos do povo. E a minha vizinha também estava de resguardo e deu de mamar a meu filho, deu aos dois meninos. $E$ depois meu filho continuou mamando no meu seio. Assim que nascia eu amamentava, os meus filhos e os dos outros. $\mathrm{Eu}$, com o peito que nem uma vaca leitera, dava de mamar aos filhos dos outros, os das vizinhas que tinha tido filho. Depois que eu tive ela, aí com seis meses, eu tive que me operar, ou operava ou morria e minha cunhada teve filho igual comigo e ela ficou amamentando minha filha. Já essa outra, quando eu passei internada uma semana ou foi duas, ela mamou no peito de uma prima minha. Agora com cinco anos ainda mama, é porque eu não dou o peito, mas se eu der ainda mama. Quando eu não dou mama na vizinha, aí, da frente.

A prática de amamentação cruzada é aceita culturalmente como uma forma de doação, um gesto solidário realizado por mulheres que, em geral, com grande produção de leite, conseguem amamentar seus filhos e outras crianças cujas mães, por algum motivo, estejam impossibilitadas de o fazer. Conforme o DSC. 37, as mulheres da Comunidade Mangabeira adotam esta prática com naturalidade. Há uma troca de favores entre as nutrizes, com intuito de garantir a alimentação da criança nos períodos em que as mães se ausentam ou estão afastadas, temporariamente de seus filhos. O costume parece inserido no cotidiano dessas famílias, criando uma familiaridade entre as nutrizes e as crianças. A relação de parentesco ou amizade não parece ser um limite para que mães se ofereçam a amamentar a criança de outra mulher, esta prática se dá no seio familiar e fora dele, basta ser percebida a necessidade. Quanto mais próximas são, mais a mãe solidária sentir-se-á responsável por beneficiar a outra criança que não é seu filho. Também, não está relacionada, necessariamente, à demanda por manter a criança em aleitamento exclusivo, pois algumas crianças já tiveram outros 
alimentos introduzidos em sua dieta, e mesmo assim, recebem as mamadas rotineiras que seriam oferecidas por suas mães.

Portanto, o aleitamento cruzado é interpretado por essas mulheres, como prática que é exercida naturalmente pela nutriz que se vê em condições de compartilhar o seu leite com outras crianças, sem prejudicar a alimentação de seu filho, respondendo a uma demanda em manter o mais próximo possível o esquema de amamentação ao qual a outra criança está habituada, para que sua mãe dê continuidade a esse cuidado, sem a necessidade de interrupção por causa de seu afastamento.

Além de solidária, a amamentação cruzada visa a manter uma rotina alimentar e de cuidado com a criança, afastando a imagem do abandono materno pela sua ausência física.

A amamentação cruzada é uma prática muito antiga na nossa civilização e que vem sendo repassada pelos séculos, em diferentes contextos. No entanto, no Brasil, a Portaria N. ${ }^{0} 1.016$ de 26 de agosto de 1993, do Ministério da Saúde, que institui as Normas Básicas para a implantação do sistema "Alojamento Conjunto", nas maternidades como forma de incentivo ao aleitamento materno, determina a proibição que as mães amamentem outros recém-nascidos que não os seus.

Apesar de o aleitamento cruzado ser uma prática não recomendada universalmente, alguns estudos no Brasil apontam a ocorrência deste, por algumas nutrizes (BITAR, 1995, SILVA, et al., 2010; TOMELERI, MARCON, 2009).

Assim, confirmando o resultado deste estudo, Tomeleri e Marcon (2009), identificaram a prática da amamentação cruzada como uma ocorrência recorrente na família e visto como um processo natural. $\mathrm{Na}$ concepção dessas famílias, o importante é que criança receba leite humano, não importando de quem.

Em outros estudos, a amamentação cruzada também foi citada como tópico a ser esclarecido às nutrizes. Assim, as mães devem ser orientadas a não amamentar outras crianças que, não seu filho, no intuito de evitar a contaminação de seus bebês, com patógenos que podem ser encontrados no leite materno, incluindo o HIV. E os profissionais de saúde precisam 
conhecer as crenças e as práticas dessas mães para então planejar, a melhor forma possível, de assistência a ser prestada ao binômio mãe-filho (FREITAS et al., 2006; TOMELERI; MARCON, 2009).

\subsubsection{TEMA 3 - Fragilidades na valorização da amamentação}

São muitos os elementos que determinam a complementação precoce da amamentação ou o desmame, durante a vivência desse processo para as mulheres moradoras da Comunidade Mangabeira.

O processo de amamentação nessa comunidade é permeado de dificuldades objetivas, mas muitas mulheres conseguem superar esses obstáculos e estabelecem o processo de amamentação de seus filhos, mesmo que mantenham uma prática de amamentação não exclusiva e no período dos primeiros seis meses de vida de seus filhos.

Os elementos que podem levam as mulheres à complementação da amamentação ou desmame se mostram como causas biológicas e culminam em elementos de cunho social, vinculados a percepção materna sobre a dinâmica do processo de amamentação em sua vida. As causas físicas ou biológicas são desde as mamas feridas, a avaliação materna que seu leite que é pouco e não sustenta seu filho, até intuir que a amamentação não protege seu filho de doenças. Já as sociais envolvem a necessidade de volta a trabalhar e assim ter que deixar seu filho na creche, crenças que permeiam o processo de amamentar e que são repassadas em seu meio social. 
Quadro 4 - Temas 3: Fragilidades na valorização da amamentação

DSC. 38 Amamento com peitos feridos

DSC. 39 Nunca gostei de amamentar, por isso dou gogó

DSC. 40 Meu leite não sustenta nem satisfaz meu filho

DSC. 41 A criança não quer mamar

DSC. 42 Deixei de amamentar para trabalhar

DSC. 43 Amamento algumas vezes na creche

DSC. 44 As crenças e crendices sobre a amamentação

DSC. 45 Qualquer criança pode adoecer mamando ou não

DSC. 46 Amamentar tem o lado bom e o lado ruim

Assim como no Modelo Pesando Riscos e Benefícios, as mulheres deste estudo, que se determinam a desmamar seus filhos, percebem que os motivos do desmame são mais fortes que os motivos que as fazem amamentar, por isso são capazes de justificar a decisão de não amamentar mais, motivadas pelas suas interpretações e significados da amamentação para si (SILVA, 1997).

É importante ressaltar que a amamentação só é exposta ao risco da complementação precoce ou do desmame, quando passa a não mais atender à medida de sanar a fome, isto pode ocorrer com a disponibilidade dessa mulher em poder usar outros recursos para alimentar seu filho, mesmo que inadequados, o desmame oportuno, e complementado após os dois anos, é uma pratica conseguida por poucas. Assim, nesse contexto, todas as crianças estão sujeitas à complementação ou desmame precoce.

DSC. 38 Amamento com peitos feridos

Assim, quando eu cheguei do hospital, ele chorava bastante e não estava conseguindo mamar, eu não tinha nenhum bico e tive que fazer com aquelas bombinhas, mas graças a Deus toda vida eu dei de mamar com esses peitos assim rachados, aquelas feridas são muito ruins. No começo, quando a gente vai dar de mamar, fere um pouco, mas depois acostuma. Agora que ela já tem dentes machuca e feria sempre que ela 
mamava, chegava até a sangrar. Ficava inchado, todo doído, que eu não podia nem apertar. Aí, eu adoeci dos peitos, estavam cheios e ficou aquele vermelhão. Mesmo assim, chorando, eu aguentava e acho que consigo, eu não desisti, meu filho mamava nos peitos feridos, colocava o seio na boca dele, chorava, gritava, mas colocava.

No estabelecimento do processo de amamentação, a nutriz passa por várias situações, que é interpretada por elas, como um sofrimento, especialmente, na dimensão física. Os problemas na mama são os mais comuns e podem ser causados por vários motivos. Entre eles, a anatomia desfavorável da mama e a dificuldade na adaptação da criança ao mamilo. Esse problema é interpretado como mais um desafio a ser enfrentado por essa mulher e pesará em sua avaliação no caminho que decidirá sobre a amamentação. Mas, a depender de sua motivação e determinação, como expresso no DSC. 38, a mulher sente-se segura para enfrentá-los, porque a sua experiência demonstra que essas intercorrências são logo resolvidas.

Estudo de Nakano (2003) afirma que o comprometimento materno, advindo dos ideais culturais, cria a expectativa que todas as mães se adaptem às necessidades do filho. Assim, as intercorrências de lesão de mamilos, se não forem bem resolvidas tornam-se um obstáculo para a manutenção da amamentação (SHIMODA; SILVA; 2010). Dessa forma, como mostra a fala das mulheres deste estudo, ela precisa superar as dificuldades e manter o empenho para tal, assim ela consegue dar continuidade à amamentação. Por outro lado, a percepção própria sobre a experiência de amamentar supera concepções coletivas e pode determinar a decisão materna quanto à amamentação.

O DSC. 39 traz a vivência de mulheres que declaram não gostar de amamentar. Seus motivos variam, desde os desconfortos mamários comuns nesse processo à dedicação integral que o recém-nascido requer para manter a amamentação exclusiva.

DSC. 39 Nunca gostei de amamentar, por isso dou gogó

Nunca gostei de amamentar, eu dava, porque era o jeito. Eles tudo novinho, aí, tinha que dar um pouquinho, mas nunca fui fã de dar 
mamar, porque dói, dói, logo no começo tem menino que morde com força. Nunca gostei, eu dava porque é filho da gente, a gente tem que amamentar, mas quando ele estava assim com três meses, quatro meses, já começava a dar um comezinho a ele, um gogozinho morno e o menino só que mama, não deixa fazer nada. Com três meses eu já ia deixando, por causa do gogó. Quando o menino tá ficando assim já taludo, a gente que mora no sítio não tem condições, toma um cafezinho pouquinho à noite para dar de mamar aquele menino veio à noite todinha não tem quem aguente. E era muito difícil (amamentar), porque, a gente era bem desarmado, trabalho pouco e o trabalho sendo pouco, o alimento é pouco. Da minha outra filha assim que ela chegou em casa, eu não tinha leite, o peito estava seco. Minha mãe fez uma mamadeira de gogó e deu, quando foi depois que o leite chegou, o meu peito já estava ferido, doendo, cortado e sangrando e eu não deixei mais ela mamar.

Diante de outras dificuldades mais próprias de uma população carente de recursos, estas mulheres também apontam o esforço físico não só em manter vigília para as mamadas frequentes, mas a carência no atendimento às suas necessidades básicas, especialmente de alimentação para atender às necessidades da criança. Este sentimento gera desconfortos e desgaste físico e emocional que leva a mulher a desgostar de amamentar - um sentimento aliado ao dever, ao atendimento de expectativas sociais e que ela também se apropria, mas que se dissolve no decorrer do processo, na impossibilidade, interpretada por ela, de dar conta de superar tantas dificuldades.

Os sentimentos de dor e desconforto, por ter seu peito ferido, junto à falta de apoio familiar, fazem com que algumas mulheres sintam-se incapazes de superar tal adversidade, que outras mulheres de seu convívio já superaram. Assim afirma que a dor ao amamentar é uma importante causa de desmame (BIANCUZZO, 1999).

É preciso atentar, que assim como neste estudo, o modelo Pesando Riscos e Benefícios, desenvolvido por Silva (1997), aponta que um dos indicadores de qualificação da experiência de amamentar, para as mulheres, está no seu sentimento de capacidade para amamentar, ou seja, uma constante avaliação de sua capacidade física e emocional de produzir leite e 
de também, se ver em condições de saúde e bem-estar para atender às necessidades da criança. Caso a mulher perceba mais prejuízos ou danos para si, cansaço excessivo ou desgaste, a continuidade da amamentação pode estar prejudicada, pois a mulher pode optar ou sentir necessidade de poupar-se, por não se perceber em condições de manter o aleitamento materno.

Silva (2007) detalha essa situação afirmando que é necessário considerar a possibilidade de que a amamentação nem sempre se concretize como uma experiência positiva, sendo muitas vezes uma sobrecarga, pela obrigação, pela expectativa da sociedade e pelos múltiplos papéis que a mulher desempenha como mãe e mulher. O trabalho de Osório e Queiroz (2007) mostra que a amamentação pode limitar e interferir significativamente na vida da mulher, levando à manifestação de sintomas de impaciência, irritação e até mesmo raiva.

Nessa experiência de amamentar alguns meses, os sentimentos negativos em relação à amamentação vão aumentando diante das dificuldades que vão surgindo e a mulher interpreta e acredita que ela não consegue e não tem possibilidades de enfrentá-las. Nakano (2003), em seu estudo, afirma que só a minoria das mulheres consegue expressar e deixar prevalecer os imperativos de seus corpos, levando em detrimento à amamentação, isso por conta de todo ideal de maternidade instituído. Entre essas e outras situações, está a ideia de que a amamentação toma muito tempo de cuidados com o seu filho, e sua situação de vida na pobreza não permite que ela tenha tanto tempo dedicado a amamentar, urge o atendimento de outras necessidades.

Shimoda e Silva (2010) chamam a atenção para o fato de que as mães, por não terem tempo para outras atividades, levam a decidir pela introdução precoce de outro leite, pois outra pessoa pode alimentar a criança. Assim essa mulher prioriza suas necessidades ou do conjunto familiar (SILVA,1997).

Alguns autores consideram, com base em seus estudos, o apoio familiar à mulher, especialmente nesse momento de vida é necessário para adaptação, e apontam caminhos para solução, como a socialização das 
tarefas domésticas entre os familiares, principalmente os companheiros (NAKANO, 2003)

As mulheres deste estudo, também avaliam que a produção de leite para seu filho demanda um esforço físico que seu organismo não possui e, por conta da sua situação de pobreza, acompanhada de pouca oferta alimentar, que leva seu corpo a não conseguir suportar esse processo. Nesse caso, a situação de miséria e pobreza, quando vista na perspectiva de sua repercussão para a saúde materna, é determinante para que mulher se decida por amamentar ou desmamar, isso pode ser confirmado através de sua fala "E era muito dificil (amamentar), porque, a gente era bem desarmado, trabalho pouco e o trabalho sendo pouco, o alimento é pouco”. Portanto, essas mulheres avaliam e relacionam que em uma vivência de pouca disponibilidade alimentar, seu corpo não suportará a demanda necessária para alimentar o seu filho.

O DSC. 40 Mostra a percepção das mulheres deste estudo quanto à avaliação de seu leite.

DSC. 40 Meu leite não sustenta, nem satisfaz meu filho

Essa daí, não teve leite não, quando nasceu ficava chupando e só saía aquela aguinha e eu fui logo colocando nos peitos que ficavam bem grandões que ardiam e doíam, mas depois de dois meses saía a boniteza. $O$ primeiro eu comecei a amamentar e achava que ele não ficava satisfeito, aí comecei a dar um leitinho e ele foi abusando do peito. Era assim, não tinha muito leite, não achava que ficava satisfeito. Disseram que amamentar era saúde para o bebê, eu acho bonito, quem amamenta até um aninho, mas eu não tinha como, eu fazia de tudo, mas não tinha jeito para dar de mamar até pelo menos os seis meses, eu não conseguia e não ia deixar os bichinhos ficarem com fome, por isso partia para dar o leite, para dar massa e assim eu ia levando. Eu dou gogó, porque ela não sustenta com o peito. Quanto eu fui fazer os exames de sangue, disseram que eu estava com muito pouco sangue, que é pouquinho e fraco. Eu acho que é o certo amamentar, eu errei, porque eu dei leite e ele abusou e não queria mais o peito, queria o bico da mamadeira que era mais fácil, mas 
por mim eu tinha amamentado por um ano, dois, o tempo que eu tivesse leite.

Embora possa desejar amamentar ou estar motivada a fazê-lo, a mulher está sujeita às suas interpretações, em especial com base nas manifestações de comportamento da criança, para acreditar que produz um leite com sustância e quantidade adequadas para a satisfação da criança. É nessa linha de pensamento, que Silva (1997) esclarece que as mulheres buscam pistas no comportamento de seus filhos para avaliar sua capacidade de amamentar, do ponto de vista de produção de leite adequado em qualidade e quantidade. Assim, observa-se que as mulheres deste estudo também apresentam esta avaliação continuada de sua capacidade de amamentar, ao manifestarem sua interpretação sobre o efeito de baixa saciedade de seus filhos ao serem amamentados por elas, levando à introdução de outros leites ou comidas.

É interessante notar que, ao desmamar total ou parcialmente a criança, pela justificativa ancorada na sua interpretação de manifestações de não saciedade da criança, ela também busca justificar a razão pela qual seu leite foi desqualificado. Nesse caso, as mulheres encontram a razão em sua condição de saúde, estabelecendo a relação da produção do leite com resultados de exames sanguíneos, que podem mostrar um deficit de alguns elementos, mesmo que em um nível muito elementar, sujeito a sua interpretação e reforçado, provavelmente pela carência de orientações profissionais para a interpretação correta de seu estado de saúde e relação com a lactação.

Nesse processo de avaliação, a falta de conhecimentos de algumas mulheres, sobre amamentação, pode gerar incoerências, como não diferenciar que o leite materno apresenta características físicas que vão mudando conforme a fase da amamentação, como pode ser visto na fala “quando nasceu ficava chupando e só saía aquela aguinha”, assim o colostro apresenta-se claro, e essas mudanças físicas do leite não interferem na sua qualidade. Corroborando com esta pesquisa as mulheres estudadas por Nakano (2003) também não consideram o colostro um alimento que dê sustento ao filho, entretanto não deixam de oferecê-lo ao bebê. 
Assim, ela faz a opção pela introdução de outro alimento lacto para seu filho, em substituição à oferta de seu leite materno. Todos esses elementos são avaliados e levam algumas a decidirem pelo desmame precoce. Esses achados corroboram com Shimoda e Silva (2010), em que algumas mulheres avaliam e interpretam com base na sua percepção que a criança corre o risco de não estar bem nutrida em consequência de problemas na produção de seu leite, sendo esse um dos fatores para a introdução de outro leite ou outro alimento na dieta da criança. Isso é confirmado pelo modelo "Pesando riscos e benefícios" o qual define que a mulher utiliza sua avaliação do leite que produz, e justifica o desmame quando considera o volume ou a qualidade insuficiente, priorizando a necessidade nutricional da criança, segundo sua interpretação. E, é esse olhar da percepção da mulher sobre o comportamento da criança que é abordado no DSC. 41.

\section{DSC. 41 A criança não quer mamar}

Meus filhos desistiram, não quiseram, foi problema deles. Uma deixou de mamar com cinco meses e outra com dois meses. Minha filha mamava e de repente ela enjoou, eu botava o peito na boca dela, para ela mamar, mas não tinha jeito, ela engunhava. Eu não sei por que deixou, não quis mais pegar o peito e não é o leite no peito que falta. Toda vez que eu colocava o peito na boca, ela colocava para fora, eu ficava tentando, tentando e tive que comprar o leite e dar. Queria que ela mamasse que nem a minha outra filha. Eu ainda adoeci dos peitos cheios.

$\mathrm{O}$ comportamento da criança quanto às dificuldades de sucção e deglutição é interpretado, por algumas mães deste estudo, como indicativo de não aceitação do leite materno e, consequentemente, rejeição do processo de amamentação. Essa mesma relação foi identifica por Silva (1997). A aceitação ou não, por parte da criança, também está condicionada ao processo de ingestão do leite, por isso, quando a criança regurgita ou vomita, isso também é visto como rejeição pela mulher. A interpretação da rejeição do peito pelo filho significa dizer que, caso ela insista, poderá 
colocar em risco a saúde de seu filho. Por isso ela não tem outra saída a não ser oferecer outro leite.

Analisando esse resultado aos achados por Silva (1997), é possível compreender que existe uma tentativa por parte dessas mulheres em justificar sua decisão por não amamentar, já que ao decidir pelo desmame, implicitamente, elas estão considerando suas necessidades. O que nem sempre fica evidente, mas quando se trata de algo mais concreto ou objetivo, a decisão é pautada de forma explícita como é possível ver no DSC. 42 , em que a mulher faz opção pelo retorno ao trabalho.

\section{DSC. 42 Deixei de amamentar para trabalhar}

Logo que nascia eu já dava comida, tomou leite, chá e peito para ir acostumando e nunca tiveram nada. Não tinha como comprar o leite mais caro, porque meu marido não estava trabalhando, mas comprar o leite mais barato não pesa, pois é o alimento delas e têm que acostumar para não ficar só no peito, pois quando eu for trabalhar, ela não vai ficar sofrendo em casa. Quem trabalha, tem que ensinar o peito e o gogó para acostumar e ficar melhor, porque o menino que só mama dá trabalho de ficar com o povo. Eu queria trabalhar e deixava ele com a minha sogra. Eu tive que trabalhar e trabalhava muito distante e a avó dele, que ficava com ele, começava a dar mamadeira e eles foram deixando de mamar. Quando eu chegava já tinha passado as horas dela mamar, por isso ela mamou pouco.

Alguns estudos apontam que as mulheres que trabalham fora apresentam cerca de seis vezes mais chances de complementar a oferta de leite de peito com outros leites ou alimentos, como comida de panela, fruta em pedaço, mingau, sopa ou papa de legumes. Seus filhos têm também em torno de quatro vezes mais chances de terem consumido leite artificial (MORGADO et al., 2013).

Outros estudos ressaltam, ainda, que a ausência de uma rede de apoio social pode contribuir para a interrupção do aleitamento materno e para a decisão por outras escolhas alimentares, como a oferta de leite artificial em mamadeira que, satisfazendo o lactente, deixaria a mulher com mais tempo 
para outras tarefas (SOUZA, 2006; RAMOS; ALMEIDA; 2003; JÓIA 2006).

Arantes (1995), em seu estudo, descreve como o retorno ao trabalho provoca mudança nos hábitos alimentares das crianças, pois quando a mãe decide desmamar um pouco antes ou no momento do retorno ao trabalho, inicia-se um processo com diminuição da frequência de mamadas, com isso diminuição do período de sucção e introdução de outros alimentos, dentre os quais, o leite de vaca, por meio da mamadeira. Tudo isso, associado à falta de drenagem do leite, provoca o desestímulo da glândula mamária, levando à diminuição do volume de produção láctea. Dessa forma, a diminuição do volume de leite e a maior facilidade de extrair o leite da mamadeira levam à recusa do seio materno pela criança, concretizando o final do processo de desmame.

Outra importante questão que pode favorecer ao desmame é a entrada das crianças na creche, essas situação é descrita no DSC. 43.

\section{DSC. 43 Amamento algumas vezes na creche}

Depois de seis meses ela fica na creche, passa o dia todinho lá, eu estava precisando, botei ela na creche pra eu trabalhar. Eu vinha dar de mamar a ela na creche, saía e voltava, no começo era sempre assim. Mas tinha dia que eu não ia dar o peito e depois não fui mais, eu não vou não sabe, só à noite, quando ela chega em casa. Já esse outro, eu só posso colocar na creche, quando ele tiver comendo outras coisas (outro alimento fora a mama).

Saindo do âmbito de motivações físicas e biológicas, e aproximandose de uma dimensão mais social, a implantação de uma creche em uma comunidade tão carente é de grande importância. Como a maioria das mulheres deste estudo trabalha em casa ou próximo à sua casa, o espaço da creche poderia ser mais um estímulo à continuidade da amamentação de seus filhos até dois anos. Mas não é o que vem ocorrendo na comunidade. As mães, ao deixarem seus filhos na creche em período de tempo integral, não retornam para amamentá-los durante o dia e demonstram um movimento de acomodação, não explorando ou aproveitando este espaço e 
sua proximidade geográfica para dar continuidade ao cuidado da criança, especialmente, no que concerne à possibilidade de manter a frequência das mamadas diárias. Nesse caso, a creche representa um distanciamento físico entre a mãe e filho, não necessário e possível de ser controlado, em especial para as mulheres dessa comunidade que em grande parte permanecem em seu domícilio ou cuja atividade é quase totalmente autônoma, não se percebendo impedimentos de sua visita à criança para manter a amamentação.

Poucos estudos no Brasil têm pesquisado sobre o tema amamentação em creches. Sabe-se, com base em diversos estudos, sobre aspectos nutricionais, que as creches constituírem um possível fator de proteção do estado nutricional, visto que possibilitam uma oferta alimentar adequada, porém mesmo que estas instituições sejam responsáveis por dois terços da ingestão nutricional total da criança, não anula a exposição das crianças às precárias condições habitacionais e de saneamento básico que predispõem à aquisição de processos infecciosos recidivantes, com consequente prejuízo, principalmente para os menores de 24 meses, período que ainda se recomenda o aleitamento materno (ZÖLLNER; FISBERG; 2006; OLIVEIRA et al., 2013).

Ao delegar às funcionárias da creche os cuidado com alimentação de seus filhos, algumas dessas mulheres deste estudo demonstram que a responsabilidade que antes era exclusivamente sua, agora também é da creche. A estada dos filhos na creche em muitas situações tem como motivação a necessidade de retorno dessas mulheres ao trabalho, em que elas estabelecem uma outra rotina no acompanhamento da criança, que pode ir se modificando ao longo do tempo, seja pela confiança na instituição ou por acomodação, uma vez que elas têm acesso irrestrito e proximidade do local.

Fica evidente, portanto e em consonância com Braga, et al. (2009), que a creche precisa desenvolver um papel proativo em relação ao incentivo da amamentação até 24 meses, pois as mães precisam ser incentivadas nesse processo, não podendo, portanto, as creches esperarem, apenas a iniciativa materna. 
$\mathrm{Na}$ composição do DSC. 44, As crenças e crendices sobre a amamentação foram reunidas as ideias que mostram a convicção de algumas mulheres sobre crenças populares que são adotadas em seu cotidiano e na sua prática de amamentar e o quanto estas podem ser influenciadas quanto ao curso da amamentação, desde suscitar dúvidas sobre a pertinência em manter a amamentação diante de outra gravidez, até a convicção íntima de algumas mulheres em priorizar a estética das mamas em detrimento da amamentação

DSC. 44 As crenças e crendices sobre a amamentação

Logo quando ela nasceu, eu dava de mamar à outra, amamentava de barrigona, nunca parei não de dar, mas tinha uma história que a menina que estava dentro secava. A parteira é que me ensinava e disse que quando eu fosse dormir era para ter cuidado e não deixar o menino arrotar no peito, porque aquele arroto ofende o leite e ofende a mama da criança. Se ela arrotar, você ver pega a bundinha do menino e passa no seu peito. Assim ela me ensinava e uma vez eu tive, o menino deu um arroto, mais as mulher do sítio é muito inteligente, Benza te Deus, e meu peito pedrou, ficou deste tamanho e vermelho, eu disse: Ave Maria, aí veio uma rezadeira e disse ói, pegue ele e dê de mamar ao contrário e bata com a bunda dele nua, eu bati três vezes o leite voltou, sério mesmo despedra e despedrou, e o meu pai também rezava muito no meu peito. Eu tinha muito leite e se não desse, o leite se perdia e ficava derramando. $E$ eu tirava nas pedras, derramava nas pedras quentes, aí secou e mãe dizia que quando chingasse o peito ele secava. O povo dizia que fazia mal, mas quando me disseram, eu já tinha tirado era muito. Aqui tem muitas mulheres que amamentam e tem muitas que não, algumas já chegam em casa e tiram o peito. Não querem amamentar porque atrapalha fazer as coisas, não quer ficar com o peito caído e o meu marido vai achar ruim. Para elas está dando de mamar é um atraso. Tem algumas que botam carrapateira no pescoço para secar, tem muita gente que não amamenta.

As crenças e crendices, como saberes populares tradicionais são difundidas na comunidade e têm sua importância cultural e prática, pois 
demonstram o quanto podem interferir na decisão de uma mulher quanto à sua disposição em amamentar. E são muitas as crenças que envolvem o processo de amamentação.

Sendo assim, faz-se necessário avaliar os impactos que essas crenças podem trazer em cada situação de amamentação vivenciada. A utilização de benzições ou outras ações baseadas nas crenças e crendices, usadas para a resolução de problemas e intercorrências do aleitamento materno significam para essas mulheres a busca de soluções em seu entorno, sem passar pela possibilidade de apoio profissional, pois representam um saber popular que trata do que comumente é considerado previsível na experiência da nutriz em seu processo de amamentar.

Além das crenças, observa-se no DSC. 44, que as mulheres deste estudo constatam que todo leite, para ser bom, deve ser doce e, assim, saboroso, o que leva à interpretação do sustento, e é determinante para que, essa mulher, ao experimentar o seu leite, possa classificá-lo. A crença do leite salgado é associada a um leite de má qualidade, e que, por isso, não deve ser oferecido aos seus filhos, como pode ser visto na fala "Nenhum dos meus filhos gostava muito do leite, acho que o leite não era muito bom, era porque o leite estava salgado.”

Outra crença, encontrada entre algumas das mulheres deste estudo, é que quando engravidam ainda amamentando, o seu feto pode "secar". Suas falas estão permeadas da percepção popular: Eu parei de dar de mamá porque eu engravidei, aí eu tive que parar para não ofender, o povo disse que a pessoa fica muito fraca. Aí eu cortei a mamação da menina, tinha que amamentar o menino, né?

Várias outras pesquisas relacionam o uso das crenças sobre as intercorrências no processo da amamentação, isso porque as crenças e os tabus fazem parte de uma herança sociocultural, determinando diferentes significados do aleitamento para a mulher (POLI, 2000; BALSAN, 2001; ARAUJO, 2002, GIUGLIANI, 2000; CARVALHO, 2002). O que só confirma os achados, nos quais a decisão de amamentar ou não o seu bebê depende da importância atribuída a esta prática que frequentemente é fundamentada nas informações transmitidas culturalmente pelo 
relacionamento avó-mãe-filha e seu entorno social também observada nos trabalhos de Ichisato; Shimo; (2001); Ramos; Almeida; (2004).

Tomeleri e Marcon, (2009) indicam que as crenças demonstram a importância do contexto familiar e social no acolhimento de práticas de cuidados relacionadas com a saúde.

O DSC. 45 apresenta a fragilidade que representa o conceito de excelência da amamentação, quando algumas mulheres, baseadas em sua prática, desvalorizam os benefícios do leite materno e assim justificam sua escolha pela complementação ou desmame.

\section{DSC. 45 Qualquer criança pode adoecer mamando ou não}

Eu digo que a diferença é muito pouca, porque apesar dele ter mamado muito, ele era alérgico e o corpo dele pocava todinho. É tudo igual, todo menino adoece. Essa menina é tão doente e nunca tomou gogó e nem pegou chupeta, nem nada, as outras são mais sadias.

Um dos importantes motivos que levam as mães a estabelecere um processo de amamentação com seus filhos é ter a certeza de que a criança que mama é mais saudável. Esse conceito é e foi amplamente divulgado pela mídia e profissionais de saúde no nosso País e está também presente nas falas de parte das mulheres deste estudo como motivação para a prática de amamentar.

No entanto, segundo é possível apreender do conteúdo do DSC. 45, as mulheres reforçam o conceito elaborado por Silva (1997), de que um dos indicadores de qualidade da amamentação, adotado pelas nutrizes, é a relação que as mães estabelecem entre o aleitamento materno e a ocorrência de doenças em seus filhos. A observação e interpretação de que, mesmo amamentado, essa criança é percebida pelas mães como doente, põe abaixo essa importante motivação, que pode vir a influenciar em uma decisão negativa à amamentação, para ela e para outras mães de seu convívio. Dessa forma, a amamentação perde seu significado de cuidado, e se alinha a qualquer outro alimento em qualidade, independente de atributos objetivos ou subjetivos que possam ser considerados como motivação para o seu exercício de nutriz. 
A qualificação da amamentação, também depende de conforto físico, emocional, percebido pela mulher em sua experiência, conforme pode ser observado no DSC. 43, em várias situações as mulheres deste estudo, sentem-se incomodadas ao amamentar. Mesmo percebendo que é um período de sua vida, elas demonstram a dificuldade em superar essa fase, dando continuidade ou não ao aleitamento materno.

DSC. 46 Amamentar tem o lado bom e o lado ruim

Eu gostava um pouquinho de amamentar, não achava ruim, eu achava normal, é um momento passageiro. É bom porque o leite do peito é saudável e é ruim porque meus peitos doíam e quando ia sair, não tinha com quem deixar meu filho, pois, ele só mamava. E é uma coisa ruim amamentar no meio do povo, quando o menino começa a chorar, tem gente que bota o peito para fora, eu achava feio e cobria. Dou de mamar em casa, quando saio com ela enrolava um pano, para dar o peito. Não é muito bom não, tem dia que eu ficava aperreada, para fazer as coisas, mas também não fazia muita coisa pesada. Mamava de instante em instante, só tomava uma folguinha quando ele dormia, mas quando acordava já queria estar no peito, dormia à noite todinha no peito, dava uma agonia, não tinha como aguentar, até feriu. Além disso, quando eu amamentava, o estômago doía muito, dava fome, e a pessoa não tem sustância, o estômago ficava vazio, de tanto peito, peito, peito e dava tontura, se amamentasse de manhã e eu não comesse logo só faltava desmaiar. É uma coisa estranha, tinha gente que achava bom, tinha quem achasse ruim, eu achava normal.

As mulheres deste estudo qualificam a sua experiência de amamentar, segundo os sentimentos que essa prática provoca nelas, em seu cotidiano, pela vivência de situações de esforço físico e emocional que devem despender nesse processo. Essa experiência, assim pode ser qualificada a depender da importância atribuída pela mulher ao que elas podem nominar de vários incômodos provocados pela amamentação. Estas questões podem ser elencadas em um gama de situações, que vão desde as 
questões de não poder sair de casa por vergonha da exposição de seu corpo em público ao amamentar, até os incômodos de sentir dor e fraqueza.

Diante de um certo sentimento de resignação e dever a ser cumprido, a mulher amamenta sem demonstrar entusiasmo ou convicção na prática, sem dar propriamente um sentido à ação, o que pode ser compreendido quando ela reflete: "É uma coisa estranha, tinha gente que achava bom, tinha quem achasse ruim, eu achava normal”.

Alguns estudos apontam que a amamentação pode se mostrar uma experiência desagradável, isso porque exige esforço físico da mulher, já que o ato de amamentar está diretamente ligado ao seu corpo. Vivenciar a amamentação significa, para a mulher, experimentar momentos de cansaço (ARANTES, 1995). Benedett (2013) considera que esse é um dos desconfortos mais difíceis de ser revertido, pois a nutriz se encontra na dependência da demanda da criança.

No cotidiano da amamentação, a mulher enfrenta uma série de conflitos e contradições que são avaliados continuamente. Suas atitudes são reelaboradas a cada situação encontrada, e é através dessas interpretações que a mãe percebe-se segura ou insegura quanto à sua condição de amamentação. Vários estudos também descrevem a avaliação das mulheres durante sua vivência do processo de amamentação com sentimentos de ambiguidade (SILVA, 1997; ARANTES, 1995). É possível detalhar melhor esse processo com base em outros autores, assim a amamentação traz consigo uma vivência de momentos positivos e ao mesmo tempo momentos negativos. Para Arantes (1995), as afirmações sobre a amamentação como experiência boa vêm sempre em primeiro lugar, somente depois que a mulher prossegue na descrição de sua experiência é que ela passa a mostrar a perspectiva ruim do amamentar. Tudo isso, justificado pela relação direta que se faz da amamentação com o amor materno, pois a mãe que assumir somente o lado negativo de amamentar pode ser considerada "desnaturada" e culpada de não amar o seu filho.

Nesse processo de interpretar suas experiências, o comportamento da criança tem um papel ativo e importante na decisão materna de manter ou não a amamentação. Ao vivenciar o comportamento da criança, a mãe sente- 
se capaz ou não de superar as demandas expressas pelo seu filho e seguir amamentando. Mesmo que seja difícil e de muito esforço em ter que amamentar em livre demanda, atrapalhar sua rotina diária, expor seu seio e sentir-se fraca durante amamentação, essa forma de alimentação é a mais saudável para o seu filho, o que acarreta seu esforço em um período curto, por isso passível de ser superada. 


\section{5 À GUISA DAS CONSIDERAÇÕES}

FINAIS

\section{5 À GUISA DAS CONSIDERAÇÕES FINAIS}

A literatura contém inúmeras publicações que demonstram a preocupação de pesquisadores, gestores e profissionais assistenciais com o incremento da prática da amamentação e inovações, que possam assegurar a motivação e excelência do desempenho materno na aderência ao aleitamento exclusivo e manutenção do Aleitamento materno, para a criança até idade de dois anos.

Muitos trabalhos têm abordado temas que buscam aprofundar o conhecimento sobre os determinantes da atitude e comportamentos maternos, a oportunidade e prontidão das mulheres para amamentar os filhos.

O modelo Pesando Riscos e Benefícios, cujos pressupostos teóricos foram utilizados neste estudo, traz em sua essência que a mulher é agente da amamentação; ela observa, percebe, estima, avalia e interpreta para si a maneira como ela se vê na situação de amamentar, o quanto essa experiência cabe em sua vida, em seus projetos atuais e futuros, e atende a suas necessidades, a da criança e demais membros da sua família. Sua percepção sobre esta prática pode ser influenciada por diferentes objetos sociais de seu entorno atual ou projetos futuros, uma vez que planeja e almeja o porvir, e visualiza a sua vivencia de amamentação nesse contexto.

Ainda, segundo esse modelo, a amamentação é um processo dinâmico que pode ter novos elementos percebidos e interpretados de diferentes formas a cada dia; a mulher faz, continuamente, avaliações de como a amamentação contribui ou causa algum tipo de prejuízo, para ela, para a criança ou para as demais pessoas significativas que podem ser afetadas de forma positiva ou negativa, segundo sua perspectiva, pelo fato de ela se dedicar à amamentação do filho.

Assim segue o processo de amamentar e para cada mulher, uma nuance de cor ou de forma, ou seja, o peso e valor atribuídos aos objetos 
sociais objetivos ou subjetivos, da sua experiência atual ou passada, podem representar e diferenciar, simbolicamente, elementos determinantes de suas ações. Percebe-se que há similaridades na maneira como as mulheres vivenciam a prática de amamentar, no que tange ao eixo do processo continuado de analisar, avaliar, perceber, interpretar e atribuir significado à amamentação, segundo as prioridades que estabelecem para si ou para outros significantes. As mulheres deste estudo indicaram que também seguem um eixo estimativo e avaliativo nesse processo, que pode ser compreendido, segundo o modelo Pesando Riscos e Benefícios, avaliam o processo continuamente, amamentam por considerar isso um benefício para ela ou para os filhos, ou abandonam, por avaliar que a amamentação pode ser um risco para si ou para a criança.

Porém, em um contexto de extrema pobreza e carência de condições objetivas e subjetivas de vida, é preciso atentar para algumas nuances que podem ser significativas e determinantes na compreensão da construção dos significados que essas mulheres, deste estudo atribuem à amamentação.

Em um cenário de baixa escolaridade, vivendo na linha de pobreza, com pouquíssimas oportunidades de melhoria de vida, a perspectiva de futuro dessas mulheres repousa na esperança dos filhos terem uma vida melhor, por meio de estudos e novas oportunidades que poucas delas almejam e esperam conseguir para si.

O clima de violência externa e doméstica, juntamente com a preocupação de conseguir a cada dia o sustento diário para a sobrevivência, a instabilidade das relações conjugais e subjugo da mulher à necessidade de depender de uma figura masculina ou ter de conciliar sua responsabilidade com os filhos para o provimento de suas necessidades, parece constituir terreno fértil para a construção de um significado de amamentar, tendo como base um valor ou sentido pragmático.

É preciso considerar que a fome gravita em torno do epicentro das preocupações e demandas objetivas dessas mulheres e suas famílias. A busca pela sobrevivência impele as pessoas a buscarem o acesso, especialmente ao alimento, de formas distintas, sem perder a sua dignidade. Urge, para a maioria dessas mulheres, satisfazer as necessidades básicas, 
essenciais e depois, ir atendendo a outras demandas, em uma escala de menor urgência e prioridade.

Nesse cenário, a amamentação está revestida de diferentes significados, dependentes do momento de vida, da oportunidade e da possibilidade de conciliar sua determinação ou construção individual da experiência de amamentar, pela incorporação de valores e sentimentos sobre esta prática, mas atende também a um sentido utilitário e prático da amamentação.

Mesmo em uma comunidade com tão pouco acesso à assistência profissional, o conhecimento sobre o papel da amamentação para a criança e a mãe é veiculado. De um modo geral, as mulheres têm acesso, de alguma maneira, à informação sobre os dogmas do aleitamento - podem acreditar ou não, na importância dessa prática, podem valorizar ou não o processo e o leite materno, mas se manifestam sobre esses princípios e os utilizam em suas argumentações a favor ou contra o aleitamento, quando justificam suas próprias ações em relação à prática de amamentar seus filhos. Tais ações se refletem no tipo e tempo de duração da amamentação, a depender da sua forma de encarar a experiência de amamentar, para si, ou para o filho, ou por fatores externos que a obrigam a amamentar em circunstâncias extremas de subjugo, seja à fome ou ao medo de perder o mínimo de estabilidade afetiva e financeira que o parceiro lhe oferece, se não amamentar.

A valorização do processo de amamentar está sujeita à percepção da mulher sobre o quanto ela atribui ao aleitamento poder de agregação de sentimentos, afetividade e realização feminina, ao sentido de ser mãe. Mas também, do ponto de vista prático, ela expressa simbólica ou objetivamente, o uso do seu corpo como recurso de sobrevivência da criança, em um cotidiano que o amamentar é parte integrante de seu papel materno, mas também pode ser o instrumento fundamental para alimentar o filho.

Isso justifica, ao que parece, o fato da maioria dos filhos dessas mulheres, 57,9\%, terem recebido outros alimentos antes dos seis meses, embora pelo menos $45,7 \%$ das mulheres terem tido a experiência de ter amamentado ou estar amamentando exclusivamente, pelo menos um dos filhos, e apenas uma mulher deste estudo ter amamentado exclusivamente 
todos seus filhos, sendo que as condições de vida, entre elas, são similares especialmente na disposição financeira.

Percebe-se que a amamentação, para essas mulheres, não é exatamente um valor absoluto para a alimentação do filho, pois pode ser substituída quando ela tem acesso a outro alimento, ou a abandona quando, ao sentir-se menos confortável ou sem condições físicas de amamentar. Nesse processo, avaliar suas condições, a qualidade do leite que produz e também a aceitação do lactente e o efeito do seu leite sobre o desenvolvimento e saúde da criança têm seu lugar como elementos determinantes do curso da amamentação, de acordo com os pressupostos do modelo Pesando Riscos e Benefícios e percebido nos resultados deste estudo.

Dessa forma, a aderência dessas mulheres à amamentação exclusiva mostra-se um processo frágil, sujeito à avaliação materna e oportunidades. Do ponto de vista da experiência materna, mostra-se frágil, podendo ser considerada boa ou ruim, ou nem tão boa ou ruim, a depender da sua condição de amamentar ou da necessidade de suprir a demanda do filho, mas certamente revestida da naturalidade ou da consequência da natureza que compete à mulher a doar de si ao filho.

Em seu conjunto, percebe-se que para essas mulheres, o aleitamento é percebido como uma prática que pode ter bom efeito para a criança ou ser indiferente para determinar as condições da saúde infantil. Porém, a manutenção da amamentação, como complemento da dieta da criança, mantém-se, de uma forma naturalizada, integrante do papel social e recurso biológico materno, mesmo que complementado por outra mulher.

Assim, dois aspectos são importantes e fundamentais: a fome da criança motiva a amamentação, mas em condições outras, a amamentação exclusiva não tem valor absoluto mesmo quando representa uma alternativa ou recurso essencial para suprir a demanda do lactente.

Se por um lado, essas mulheres mostram que agem em relação à amamentação, segundo o significado que esta experiência tem para cada uma delas, seja bom, ruim ou simplesmente normal ou natural, por outro lado é preciso refletir sobre o potencial de risco ou de desapego ao processo 
de amamentar exclusivamente que essas mulheres demonstram, embora mantenham por muito mais tempo a amamentação complementada de seus filhos.

A manutenção do aleitamento por mais tempo, nessa comunidade poderia ser melhor explorada pelos profissionais de saúde que as atendem. A amamentação, embora sujeita a variáveis contextuais e introjeção de valores, crenças e significados individuais, nessa população, parece também desguarnecida de proteção, seja na melhoria de condições objetivas de vida dessas mulheres, seja na falta de acompanhamento e suporte afetivo e instrumental.

Os resultados deste estudo, desde o panorama social e econômico em que essas mulheres vivem e convivem em seu processo de gestar, parir e cuidar dos filhos, demonstra a complexidade do tecido social em que estão inseridas e a demanda por uma assistência mais abrangente do ponto de vista de aplicação de recursos e melhoria de vida dessa população. A orientação multiprofissional, suporte prático para que as famílias possam suprir, pelo menos os requisitos mínimos para o recebimento de benefícios que deixam de receber. Ainda, a orientação do alcance de alternativas para manter um mínimo de ganho que as retire da linha de pobreza; o aproveitamento dos recursos e equipamentos de saúde e de atenção à infância, como cenários de promoção, apoio e principalmente de proteção à amamentação, com intuito de melhorar e tornar mais propícias as condições e experiências de amamentação dessas mulheres e crianças.

Nesse cenário, a enfermagem, representada por elementos essenciais de uma equipe que possa atuar nesse tipo de contexto, teria de fazer a diferença, como suporte e apoio a essas mulheres. Resultados, como os deste estudo, implicam em uma reprogramação de assistência pré-natal e acompanhamento pós-parto; em exploração do espaço de creches para incentivo ao aleitamento. Também, de focalização de temas no ensino de profissionais que carecem de melhor preparo para lidar e se dedicar a populações com carência extrema de recursos. Os resultados deste estudo também incitam ao aprofundamento da compreensão dos processos de vivência da saúde e da doença dessas populações. 
Em tempos em que se busca alcançar e cumprir os objetivos do Projeto do Milênio ${ }^{6}$, com especial atenção para a nulidade da fome, proteger mulheres e sua potencialidade de amamentar, deveria ser uma ação obrigatória.

Não se garante a decisão da mulher em amamentar, mas haveria pelo menos a possibilidade de dar a ela, de fato, o direito de decidir sem expor sua prole à fome.

${ }^{6}$ O Projeto do Milênio foi especialmente constituído pelo Secretário-Geral das Nações Unidas, em 2002, para desenvolver um plano de ação concreta para que o mundo reverta o quadro de pobreza, fome e doenças opressivas que afetam bilhões de pessoas. http://www.org/Projetodomileniodasnacoesunidas.htm 


\section{REFERÊNCIAS}

ABADE, E.A.; PEREIRA, J.F. Prevalência de Desnutrição infantil em menores de 5 anos numa Comunidade Carente de Arapiraca. [Relatório de pesquisa]. Alagoas: Universidade Federal de Alagoas- Campus Arapiraca; 2009 .

ABRELPE - Associação Brasileira de Empresas de Limpeza Pública e Resíduos Especiais. "Panorama de Resíduos Sólidos no Brasil- 2009”. São Paulo: Abrelpe, 2009.

ALMEIDA, J.A.G. Amamentação: Um Híbrido Natureza-Cultura. Rio de Janeiro: Editora Fiocruz, 1999.

ALMEIDA, J.A.G.; NOVAK, F.R. Amamentação: um híbrido naturezacultura. J Pediatr (Rio J). Porto Alegre: 80(5 Supl):S119-S125, 2004.

ANGELO, M. Vivendo uma prova de fogo: as experiências iniciais da aluna de enfermagem. São Paulo,. 133 p. Tese (Doutorado) - Instituto de Psicologia, Universidade São Paulo, 1989.

ANTUNES, L.S. et al. Amamentação natural como fonte de prevenção em saúde. Ciênc Saúde Coletiva, Rio de Janeiro; 13:103-9, 2008.

ARAGAKI, I.M.M.; SILVA, I. A. Percepção de nutrizes acerca de sua qualidade de vida. Revista da Escola de Enfermagem da USP (Impresso), v. 45, p. 71-78, 2011.

ARAÚJO, L. D. S. Querer/Poder Amamentar: Uma Questão de Representação? Dissertação de Mestrado, Florianópolis: Universidade Federal de Santa Catarina, 1991.

ASSIS, A.M.O. et al. Desigualdade, pobreza e condições de saúde e nutrição na infância no Nordeste brasileiro. Cad. Saúde Pública, Rio de Janeiro, v. 23, n. 10, Oct. 2007.

ARAKATI, I.M.M. Avaliação da percepção de nutrizes acerca de sua qualidade de vida. 2008. 137f. Tese (Doutorado em Enfermagem) - Escola de Enfermagem da Universidade de São Paulo, São Paulo, 2008.

ALVES, J.E.D; CAVENAGHI S. 'O programa Bolsa Família e as taxas de fecundidade no Brasil', in T. Campello and M. Côrtes Neri (orgs), Programa 
Bolsa Família: uma década de inclusão e cidadania. Brasília, Ipea, Capítulo 14: pp. 233-245, 2013.Disponivel em:

http://www.ipea.gov.br/portal/images/stories/PDFs/livros/livros/livro_bolsaf amila_10anos.pdf $>$. Acesso em : 12 Nov, 2013.

ARAUJO, M.F.M. Situação e perspectivas do aleitamento materno no Brasil. Rio de Janeiro: Guanabara Koogan (2002).

ARANTES, I.S.C. Amamentação: visão das mulheres que amamentam. J Pediatr,(Rio J), Porto Alegre v. 71, n. 4, p. 195-202, 1995.

BADINTER, E. Um amor conquistado, o mito do amor materno. $5^{\text {a }}$ Ed Rio de Janeiro: Nova Fronteira, 1985.

BALSAN, J.A. et al. Incentivando o Aleitamento Materno . In : Santana, M.da G. \& Thoferhn, M.B. (Org.). (Re) Significando a teoria e a prática de enfermagem. Pelotas: Universidade/UFPel, 2001.

BARREIRA, S.M.C.; MACHADO, M.F.A.S. Amamentação: compreendendo a influência familiar. Acta Scientiarum Health Sci.; Paraná, 26(1):11-20, 2004.

BARKER, D. Mothers, Babies, and Disease in Later Life. BMJ Publishing; 1994.

BAZILLI, C. et al. Interacionismo simbólico e a teoria dos papéis: uma aproximação para a psicologia social. São Paulo: Educ; 1998.

BEHRMAN, J.R. The impact of health and nutrition on education. The World Bank Research Observer. 1996: 11:23-37, 1996.

BEMFAM (Sociedade Civil Bem-Estar da Família no Brasil). Pesquisa Nacional sobre Demografia e Saúde. Rio de Janeiro: Fundo das Nações Unidas para a Infância, 1997.

BENEDETT, A. A percepção da nutriz sobre os (des)confortos da pratica do aleitamento materno. 2013. 103f. Tese (Doutorado), Escola de Enfermagem da Universidade de São Paulo, São Paulo, 2013.

BERQUÓ, E; CAVENAGHI, S. Mapeamento sócio-econômico e demográfico dos regimes de fecundidade no Brasil e sua variação entre 1991 e 2000. In: 14 ${ }^{\circ}$ Encontro Nacional de Estudos Populacionais; Disponível em: www.abep.org.br. Acesso em 8 jun de 2012, 2004 
BETRÁN A.P. et al. Ecological study of efect of breast feeding on infant mortality in Latin America. BMJ;323:1-5, 2001.

BIANCUZZO, M. Maternal physical assessment and counseling. In:Breastfeeding the newborn. St. Louis: Mosby;. p. 226-304.1999.

BITAR, M. A. F. Aleitamento Materno: Um Estudo Etnográfico sobre os Costumes, Crenças e Tabus Ligados a esta Prática. Dissertação de Mestrado, Belém: Universidade Federal do Pará, 1995.

BLUMER, H. Symbolic interacionism perspective and method. Califórnia: Prentice-Hall; 1969.

BOSI, M.L.M; MACHADO, M,T. Amamentação: um resgate histórico. Rev ESP.; 1(1):17-25, 2005.

BOURDIEU, P. "O campo científico". In: ORTIZ, R. (Org.) Asociologia de Pierre Bourdieu. São Paulo: Olho d’Água, p. 112-143, 2003.

BRAGA,P. N; REZENDE, A.M; FUJIMORI, A. Amamentação em creches no Brasil. Revista brasileira de crescimento e desenvolvimento humano, v. 19, n. 3, p. 465-474, 2009.

BRASIL. Decreto $\mathrm{n}^{\circ} 5.209$, de 17 de setembro de 2004. Regulamenta a Lei $\mathrm{n}^{\circ}$ 10.836, de 9 de janeiro de 2004, que cria o Programa Bolsa Família, e dá outras providências. Diário Oficial da União, Brasília, DF, 17 set. 2004.

BRASIL. Lei $\mathrm{n}^{0}$ 11.346, de 15 de setembro de 2006. Cria o Sistema Nacional de Segurança Alimentar e Nutricional - SISAN com vistas em assegurar o direito humano à alimentação adequada e dá outras providências. Diário Oficial da União. set 18; Seção 1:1, 2006.

BRASIL. Ministério da Saúde (MS). Secretaria de Ciência, Tecnologia e Insumos Estratégicos. Pesquisa Nacional de Demografia e Saúde da Criança e da Mulher em 2006 (Relatório). Brasília: MS; 2008. Disponível em: $<$ http://www.saude.gov.br/pnds2006 $>$. Acesso em: 15 fev. 2011.

BRASIL. Ministério da Saúde. Secretaria de Atenção à Saúde. Saúde da criança: nutrição infantil: aleitamento materno e alimentação complementar. Brasília: Ministério da Saúde; 2009. 
BRASIL. Ministério da Saúde. Pesquisa Nacional de Demografia e Saúde da Criança e da Mulher - PNDS 2006: dimensões do processo reprodutivo e da saúde da criança/ Ministério da Saúde, Centro Brasileiro de Análise e Planejamento. - Brasília : Ministério da Saúde, 2009.

BRASIL. Ministério da Saúde. Secretaria de Atenção a Saúde. Departamento de Ações Programáticas e Estratégicas. II Pesquisa de Prevalência de Aleitamento Materno nas Capitais Brasileiras e Distrito Federal / Ministério da Saúde, Secretaria de Atenção a Saúde, Departamento de Ações Programáticas e Estratégicas. - Brasília: Editora do Ministério da Saúde, 2009.

BRASIL. Ministério da Saúde. Tempo médio de aleitamento materno aumenta de 296 para 342 dias em nove anos, publicada em 12 de setembro de 2009. Disponível em: http://portal.saude.gov.br/portal/, acesso em jan de 2011, 2009.

BRASIL. Ministério da Saúde. II Pesquisa de Prevalência de Aleitamento Materno nas Capitais Brasileiras e Distrito Federal. Brasília: MS; 2009.

BRUNKEN, G.S. et al. Risk factors for early interruption of exclusive breastfeeding and late introduction of complementary foods among infants in midwest- ern Brazil. J Pediatr (Rio J), Porto Alegre, 82(6):445-451. Brasil, 2006.

BURLANDY, L. Transferência condicionada de renda e segurança alimentar e nutricional. Ciênc Saúde Coletiva, Rio de Janeiro v. 12, n. 6, p. 1441-51, 2007.

BUSS, M. P. Globalização, pobreza e saúde. Ciênc. saúde coletiva [online].Rio de Janeiro, vol.12, n.6, pp. 1575-1589. 2007.

CAETANO, A.J. O declínio da fecundidade e suas implicações. In: Anais do Seminário Tendências da Fecundidade e Direitos Reprodutivos no Brasil; 2004. Disponível em: http:// www.abep.nepo.unicamp.br/. Acesso em 8 de jun 2012, 2004.

CALVASINA, G.P. et al. Fraqueza de nascença": sentidos e significados culturais de impressões maternas na saúde infantil no nordeste brasileiro. Cad Saúde Pública, v. 23, n. 2, p. 371-80, 2007.

CAPUCHA, L.M.A. Exclusão social e acesso ao emprego: paralelos que podem convergir Sociedade \& Trabalho, 3:61-69, 1998. 
CARVALHO, M.R. Manejo ampliado da amamentação. In: Carvalho, M.R., \& Tomaz, N.R. (2002). Amamentação: bases científicas para a prática profissional. Rio de Janeiro: Guanabara Koogan, 2002.

CARRASCOZA, C.K, et al. Aleitamento materno em crianças até os seis meses de vida: percepção das mães. Physis [impresso], vol.21, n.3, pp. 1045-1060, 2011.

CASAS, S.B; KLIJN, T.P. Promoción de la salud y su entorno laboral saludable. Rev Latino-am Enfermagem janeiro- fevereiro; 14(1):136-41, 2006.

CAMINHA, M.F.C. et al. Aspectos históricos, científicos, socioeconômicos e institucionais do aleitamento materno. Rev Bras Saúde Matern Infant, Pernanbuco, 10(1):25-37, 2010.

CAMPBELL, C.C. Food insecurity: a nutritional outcome or a predictor variable? J Nutr.; Campinas, 121: 408-15, 1991.

CASTRO, M.G. "Feminização da pobreza" em cenário neoliberal. Mulher e Trabalho, Porto Alegre: FEE, v. 1, p. 89-96, 2001.

CAVALCANTI, M.L.F. Conhecimentos, atitudes e práticas de pessoal de saúde sobre aleitamento materno. São Paulo, 1982. 439p. Tese (Doutorado)Faculdade de Saúde Pública, Universidade de São Paulo, 1982.

CUPUL-UICAB, L. A. et al. Reliability of reported breastfeeding duration among reproductive-aged women from Mexico. Maternal \& child nutrition, v. 5, n. 2 , p. $125-137,2009$.

CONAPO. Consejo Nacional de Población. Lactancia Materna. In: Zúñiga, E.; Zubieta, B.; Araya, C., editors. Cuadernos de Salud Reproductiva. República Mexicana.CONAPO; México D.F: p. 152, 2000.

COULON, A. Etnometodologia. Petrópolis (RJ): Vozes; 1995.

COSTA, R. G. et al. Processo de Decisão pela Laqueadura entre Mulheres Laqueadas no Centro de Assistência Integral à Saúde da Mulher. Relatório Final. Campinas: Centro de Pesquisa das Doenças Materno-Infantis de Campinas (CEMICAMP), 1995.

COULILALY, R. et al. Links betwen maternal breast-feeding duration and Québec infant's health:a population-basead study. Arethe effects different 
for poor children? Matern Child Heart J.,10: 537-43, 2006.

CHARON, J.M. Symbolic interactionism: an introduction, an interpretation, an integration. New Jersey: Prentice Hall; 2010.

CLIFFORD, M; MCINTYRE .J. Who supports breastfeed- ing? Breastfeed Rev; 16:9-19, 2008.

CNDSS - COMISSÃO NACIONAL SOBRE DETERMINANTES SOCIAIS DA SAÚDE. As causas sociais das iniquidades em saúde no Brasil: relatório final. Abr. 2008. Disponível em: $<\underline{\mathrm{http}} / / / \mathrm{www} . \mathrm{cndss}$. fiocruz.br/pdf/home/relatorio.pdf>. Acesso em: 06 abr. 2012.

DALL'AGNOL, C.M; FERNANDES, F.S. Saúde e Saúde e autocuidado entre catadores de lixo: vivências no trabalho em uma cooperativa de lixo reciclável. Revista Latino-Americana de Enfermagem, 2007. Disponível em: <http://www.scielo.br/pdf/rlae/v15nspe/pt_02.pdf>. Acesso em: 1. ${ }^{\circ}$ mar. 2011.

DAMIÃO, J.J. Influência da escolaridade e do trabalho maternos no aleitamento materno exclusivo. Revista Brás epidemiolo, 11(3): 442-52, 2008 .

DAMIANI, F. E. Gravidez na adolescência: a quem educar? Passo Fundo: Universidade de Passo Fundo, 2005.

DEMÉTRIO, F. et al. Sentidos atribuídos à adoção da amamentação nos dois primeiros anos de vida da criança: estudo com mulheres de dois municípios do Recôncavo Baiano region of Bahia, Brazil. Rev. Nutr., vol.26, n.1, pp. 5-16. 2013.

DANIELS, M.C; ADAIR, L.S. Breast-feeding influences cognitive development in Filipino children. J Nutr;135(11):2589-95. [PubMed], 2005.

DINIZ D.; MEDEIROS M. Aborto no Brasil: uma pesquisa domiciliar com técnica de urna. Ciênc Saude Colet; 15(S1): 959-66, 2010.

DA SILVA, G.M.T. Representações e vivências da maternidade nas camadas populares.

http://www.snh2013.anpuh.org/resources/anais/27/1364813290_ARQUIVO materniade,generoefeminismo.pdf $>$. Acesso em: 1. ${ }^{\circ}$ mar. 2013. 
DUAZO, P.; AVILA, J.; KUZAWA, C.W. Breastfeeding and later psychosocial development in the Philippines. American Journal of Human Biology, v. 22, n. 6, p. 725-730, 2010.

ECONOMIC COMMISSION FOR LATIN AMERICA AND CARIBBEAN (ECLAC). Statistical yearbook for Latin Ame-rica and the Caribbean, Santiago de Chile :ECLAC; 2006

EVANS, G.W.; SCHAMBERG M. A. Proc. Natl. Acad. Sci. U.S.A. 106, 6545-6549 (2009).

FADUL, F.R. et al. Fatores que contribuem para o desmame precoce. Rev.Bras.Enf., v. 36, n. 2, p. 213-20, 1983.

FALEIROS, F.T.V.; TREZZA, E.M.C.; CARANDINA, L. Aleitamento materno: fatores de influência na sua decisão e duração. Rev. Nutr. vol.19, n.5, pp. 623-630, ]. 2006.

FIELD, P.A.; MORSE, J.M.. Nursing research: the application of qualitative approaches. Maryland: Aspen Publishers; 1985.

FRANÇA, G. A. O problema da gravidez na adolescência. São Paulo: Nova Dimensão, 2003.

FREITAS, F. et al. Rotinas em Obstetrícia - $5^{\mathrm{a}}$ Edição - Porto Alegre:Artmed Editora, 2006.

FUJIMORI, E. et al. Duração do aleitamento materno em menores de dois anos de idade em Itupeva, São Paulo, Brasil: há diferenças entre os grupos sociais?. Rev. Bras. Saúde Mater. Infant.vol.10, n.1, pp. 39-49, 2010.

GALVÃO, D.M.P.; SILVA, I.A. Abordagem da amamentação nos primeiros anos do ensino fundamental. Revista da Escola de Enfermagem da USP, v. 47, n. 2, p. 477-485, 2013.

GIUGLIANI, E.R.J. et al. Breastfeeding pattern in a population with different levels of poverty in Southern Brazil. Acta Paediatr.; 85: 1499-500, 1996.

GIUGLIANI, E.R.J. O aleitamento materno na prática clínica. J. Pediatri, 76 (3): 238-52. Rio de Janeiro, 2000.

GOLDBERG, M. S. et al. Incidence of cancer among persons living near a 
municipal solid waste landfill Site in Montreal, Quebec. In:Archives of Environmental Health, v. 50, n. 6, pp. 416 - 424, 1999.

GOMES, C.M.F.M. "Segregação sócio-espacial e violência urbana no Rio de Janeiro." Anais: Encontros Nacionais da ANPUR" 10 (2013).

GONZALEZ-COSSIO T. et al. Breast-feeding practices in Mexico: results from the Second National Nutrition Survey 1999. Salud Publica de Mexico; 45 (Suppl 4):S477-S489,. 2007.

GOULART, L.M.H.F.; SOMARRIBA, M.G.; XAVIER, C.C. A perspectiva das mães sobre o óbito infantil: uma investigação além dos números. Cad Saúde Pública, 21:715-23, 2005.

GOUZIE, D.; BERGER, S.; MOORE, G. Fresh kills - teamwork leads to better understanding of potential landfill health effects, article in Hazardous Substances \& Health. Newsletter of the U.S. Department of Health and Human Services/Agency for Toxic Substances and Disease Registry. New Yorq, v. 8, n. 2. 1998.

GLUCKMAN, P.D.; HANSON M.A. Developmental Origins of Health and Disease. Cambridge: Cambridge University Press; p. 519, 2006.

GRANTHAM-MCGREGOR, S. et al. Developmental potential in the first 5 years for children in developing countries. Lancet.;369(9555):60-70, 2007.

HADAD, S.C; FRANÇA, E.; UCHÔA. E. Preventable infant mortality and quality of health care: maternal per- ception of child's illness and treatment. Cad Saúde Pública; 18:1519-27, 2002.

HAGUETTE, T.M.F. Metodologias qualitativas na sociologia.3. ed. Petrópolis: Vozes; 2007.

HAIG, D. Intimate relations: evolutionary conflicts of pregnancy and childhood. In: Evolution in Health and Disease (eds S.C. Stearns \& J. Koella), 2nd edn, pp 65-76. Oxford University Press: Oxford, (2008) .

HELLER, L.; CATAPRETA, C. A. A. Solid waste disposal in urban areas and health -the case of Belo Horizonte, Brazil. In: Waste Management \& Research, v. 21, n. 6, pp. $549-556,2003$.

HORTA, B.L. et al. Duração da amamentação em duas gerações.Rev Saúde Pública.; 41(1):13-8, 2007. 
HARDY, E. et al. Avaliação do Programa de Assistência Integral a Saúde da Mulher no Estado de São Paulo. Resultados da área metropolitana e do interior do estado. Informações relativas ao pré-natal, parto e revisto pósparto". Centro de Pesquisas e Controle das Doenças Materno-Infantis de Campinas (Cemi-camp), 1993.

HORWOOD, L.J. et al. Cognitive, educational, and behavioural outcomes at 7 to 8 years in a national very low birthweight cohort. Arch Dis Child Fetal Neonatal Ed; 79: 12-20. 2001.

ICHISATO, S.M.T; SHIMO, A.K.K. Aleitamento materno eas crenças alimentares. Rev Latinoam Enfermagem; 9(5):70-6, 2001.

INSTITUTO BRASILEIRO DE ANÁLISES SOCIAIS E ECONÔMICASIBASE. Repercussões do Programa Bolsa Família na segurança alimentar e nutricional das famílias beneficiadas: relatório técnico (preliminar). Rio de Janeiro -. Junho, 2008.

INSTITUTO BRASILEIRO DE GEOGRAFIA E ESTATÍSTICA (IBGE). Pesquisa Nacional por Amostra de Domicílios. Um panorama da saúde no Brasil. Acesso e utilização de serviços, condições de saúde e fatores de risco e proteção à saúde 2008: Brasil/IBGE, Coordenação de Trabalho e Rendimento. Rio de Janeiro: IBGE; 2010.

IPCC - Intergovernmental Panel on Climate Change. Climate Change 2007 Synthesis Report. Disponível em: $<$ http://www.ipcc.ch/publications_and_data/publications_ipcc_fourth assess ment_report_synthesis_report.htm>. Acesso em: 1 fev. 2011.

IP S. et al. Breastfeeding and maternal and infant health outcomes in developed countries. Evid Rep Technol Assess (Full Rep);(153):1-186, 2007.

INSTITUTO BRASILEIRO DE GEOGRAFIA E ESTATÍSTICA. Indicadores sociais. http://www.ibge.gov.br/home/estatistica/populacao/condicaodevida/ Indicadoresminimos/sinteseindicsociais2004/ indic_sociais (acessado em 17/Abr/2011).

INSTITUTO BRASILEIRO DE GEOGRAFIA E ESTATÍSTICA - (IBGE). Pesquisa Nacional de Saneamento Básico: 2000. Rio de Janeiro: Departamento de População e Indicadores Sociais; 2002. 
JÓIA, I.C.O.S. Percursos ambíguos: percepções de lactantes usuárias de uma unidade básica de saúde do município do Rio de Janeiro acerca dos primeiros meses de amamentação [dissertação]. Rio de Janeiro: Instituto de Estudos em Saúde Coletiva, Universidade Federal do Rio de Janeiro; 2006.

JEON, S.Y.O; MAHONY, M; KIM, K.O. A comparison of category and line scales under various experimental protocols. J Sens Stud.;19(1):49-66, 2004.

JUNCÁ, D. et al. A mão que obra no lixo. Niterói : EDUFF, 2000.

KASSAR, B.S. et al. Fatores de risco para mortalidade neonatal, com especial atenção aos fatores assistenciais relacionados com os cuidados durante o período pré-natal, parto e história reprodutiva materna; Determinants of neonatal death with emphasis on health care during pregnancy, childbirth and reproductive history. J. pediatr.(Rio J.), v. 89, n. 3, p. 269-277, 2013.

KRAMER, M.S; KAKUMA, R. The optimal duration of exclusive breastfeeding: a systematic review. Adv Exp Med Biol; 554:63-77, 2004.

KRAMER, et al. Breastfeeding and child cognitive development: new evidence from a large randomized trial. Arch Gen Psychiatry; 65(5):578-84, 2008.

LABBOK, M.H. Transdisciplinary breastfeeding support: Creating program and policy synergy across the reproductive continuum. International Breastfeeding Journal.;3(16), 2008.

LEÓN-CAVA, N. Quantify- ing the benefits of breastfeeding: a summary of the evidence. Washington DC: Pan American Health Organization; 2002.

LEFÈVRE, F.; LEFÈVRE, M.C.A. O discurso do sujeito coletivo: um novo enfoque em pesquisa qualitativa (desdobramentos). 2. ed. Caxias do Sul: Educs, 2005.

LEFÈVRE, F.; LEFÈVRE, A.M.C. O sujeito coletivo que fala. Interface Comunic., Saude, Educ., v.10, n.20, p.517-24, 2006.

LINHARES, F.M.P. et al. Aleitamento e paulo freire. Rev. Nutr. , Campinas, março / abr, Revista de Nutrição 26 (2) :125-134, 2013. 
LONG - DUNLAP, et al. Long-Dunlap K, Rivera-Dommarco J, RiveraPasquel M, Hernandez-Avila M, Lezana MA. Feeding patterns of Mexican infants recorded in the 1988 National Nutrition Survey. Salud Publica de Mexico; 37:120-129, 1995.

MAGALHÃES, R.; BURLANDY, L.; SENNA, M.C.M. Desigualdades sociais, saúde e bem-estar: oportunidades e problemas no horizonte de políticas públicas transversais. Ciência \& Saúde Coletiva, Rio de Janeiro, v. 12, n. 6, p. 1415-1421, 2007.

MAGERA, M. Os empresários do Lixo: Um paradoxo da modernidade. São Paulo: Átomo, 2003.

MARTINEZ, F.J.M.; BOSI, M.L.M. Notas para um debate. In: Bosi MLM, Mercado FM, organizadores. Pesquisa qualitativa de serviços de saúde. Petrópoles: Vozes; p. 33-71, 2004.

MARCUSCHI, M.A.L; DIONI P.A. Fala e escrita - 1. ed., 1. reimp. - Belo Horizonte: Autêntica, 208 p, 2007.

MACHADO, J.C. et al. Perdas fetais espontâneas e voluntárias no Brasil em 1999-2000: um estudo de fatores associados. Revista Brasileira de Epidemiologia, v. 16, n. 1, p. 18-29, 2013.

MAGALHÃES, K.A. et al. A habitação como determinante social da saúde: percepções e condições de vida de famílias cadastradas no programa Bolsa família. Saúde Soc. São Paulo, v.22, n.1, p.57-72, 2013.

MANI, A. et al. Poverty impedes cognitive function. science, v. 341, n. 6149, p. 976-980, 2013.

MCDADE, T.W.; WORTHMAN, C.M. The weanling's dilemma reconsidered: a biocultural analysis of breast- feeding ecology. Developmental \& Behavioral Pediatrics 19, 286-299, (1998).

McGRANAHAN, G.; SATTERTHWAITE, D. The environmental dimensions of sustainable development for cities. Geography, v.87, n.3, p.213-26, 2002.

MEAD, G.H. Mind, self and society: from the standpoint of asocial behaviorist. $8^{\text {Th }}$ ed. Chicago:the university of Chicago Press; 1972. 
MEDEIROS, L.F.R.; MACEDO, K.B. "Catador de material reciclável: uma profissão para além da sobrevivência?” Psicologia \& Sociedade; 18 (2): 6271; mai./ago. 2006.

MICHAELSEN, K.F. et al. Breast-feeding and brain development. Scandanivian Journal of Nutrition: 47(3):147-151, 2003.

MINAYO, M.C.S. Condiciones de vida, desigualdad y salud a partir del caso brasileño. In: Briceño-León R, Minayo MCS, Coimbra Jr. CEA, editores. Salud y equidad: una mirada desde las ciencias sociales. Rio de Janeiro: Editora Fiocruz;. p. 55-72, 2000.

MINAYO, M.C.S. O desafio do conhecimento: Pesquisa qualitativa em saúde. 11. ed. São Paulo: Hucitec, 2010.

MINELLA, L.S. Aspectos positivos e negativos da esterilização tubária do ponto de vista de mulheres esterilizadas. Cadernos de Saúde Pública, 14 (Sup. 1):69-79, 1998.

MIURA, P.C.O. Tornar-se catador: uma análise psicossocial. Dissertação (Mestrado) Pontifícia Universidade Católica de São Paulo, São Paulo, 2004.

MINISTÉRIO DA SAÚDE (MS). Secretaria de Ciência, Tecnologia e Insumos Estratégicos. Pesquisa Nacional de Demografia e Saúde da Criança e da Mulher (Relatório). Brasília: MS; 2008.

MONTE, C.M.G.; GIULIANI, E.R.J. Recomendações para alimentação complementar da criança em aleita- mento materno. J Pediatr (Rio J); 80(Supl. 5): 131-S141, 2004.

MONTEIRO, C.A. et al. Can infant mortality be reduced by promoting breastfeeding? Evidence from São Paulo city. Health Policy Plan;5:23-9, 1990.

MORAN, V.H. et al. An evaluation of the breastfeeding support skills of midwives and voluntary breastfeeding supporters using the breastfeeding support skills tool (BeSST). Matern Child Nutr; 1:241-9, 2005.

MORGADO, C.M.C. et al. Rede e apoio social e práticas alimentares de crianças no quarto mês de vida. Ciênc. saúde coletiva [online], vol.18, n.2, pp. 367-376. ISSN 1413-8123. http://dx.doi.org/10.1590/S1413$\underline{81232013000200008,2013}$ 
MÜLLER, F.S.; SILVA, I.A. Social representations about support for breastfeeding in a group of breastfeeding women. Revista Latino-Americana de Enfermagem (USP. Ribeirão Preto. Impresso), v. 17, p. 651-657, 2009.

NAKANO, S.M.A. As vivências da amamentação para um grupo de mulheres: nos limites de ser "o corpo para o filho" e de ser "o corpo para si" Breastfeeding experiences in a group of women: the limits of "the body for the child". Cad. Saúde Pública, v. 19, n. Sup 2, p. S355-S363, 2003.

NATIONS, M.K.; REBHUN, L.A. Angels with wet wings won't fly: maternal sentiment in Brazil and the image of neglect. Cult Med Psychiatry 1988; 2: 141-2000.

NEGI, K.S.; KANDPAL, S.D. Breast Feeding Practices in a Rural Area of District Dehradun, Uttaranchal. Indian J Prev Soc Med.;35(3 \& 4), 2004.

ODDY, W.H. et al,.Breast feeding and respiratory morbidity in infancy: a birth cohort study. Arch Dis Child 2003; 88:224-8, 2004.

OLINGER, G. Êxodo Rural: Campo ou Cidade? Florianópolis, ACARESC, 1991.

OLIVEIRA, L.P.M. et al. Duração do aleitamento materno, regime alimentar e fatores associados segundo condições de vida em Salvador, Bahia, Brasil. Cad Saúde Pública. 1992 21: 1519-30, 1992.

OLIVEIRA, L.P.M.; ASSIS, A.M.O; GOMES, G.S.S.; PRADO, M.S.; BARRETO, M.L. Duração do aleitamento materno, regime alimentar e fatores associados segundo condições de vida em Salvador, Bahia, Brasil. Cad Saúde Pública.; 21: 1519-30, 2005.

OLIVEIRA, et al. Fatores associados ao estado nutricional em crianças de creches públicas do município de Recife, PE, Brasil. Rev Bras Epidemiol, v. 16, n. 2, p. 502-12, 2013.

ORGANIZAÇÃO MUNDIAL DE SAÚDE (OMS). Global strategy for infant and young child feeding. Genebra: OMS; 2003.

ORGANIZAÇÃO MUNDIAL DE SAÚDE (OMS). Indicators for assesssing infant and young child and feeding prac- tices, part II. Genebra: OMS; 2010. 
ORGANIZAÇÃO MUNDIAL DA SAÚDE. Aleitamento ma- terno: proteção, promoção e apoio. O papel espe- cial dos serviços maternoinfantis. Femina; 2:969-4, 1992.

ORGANIZAÇÃO MUNDIAL DA SAÚDE. Estratégia global para a alimentação de lactentes e crianças de primeira infância. $<$ http://www.ibfan.org.br/do cumentos/ibfan/doc-286.pdf $>$ (acessado em 20/ Fev/2012).

ORGANIZACIÓN PANAMERICANA DE LA SALUD, OPAS/OMS. Indicadores para elvaluar las praticas de lactancia materna. Informe de una reunión. Ginebra, 1991.

ORGANIZACIÓN PANAMERICANA DE LA SALUD. SALUD EN LAS AMÉRICAS. [acessado 2008 out 8]. Disponí- vel em: http://www.paho.org/hia/vollregional.html, 2007.

OSIS, D.J.M. et al. Conseqüências do uso de métodos anticoncepcionais na vida das mulheres: o caso da laqueadura tubária Impact of contraceptive methods on women's lives: the case of tubal ligation. Cad. Saúde Pública, v. 15, n. 3, p. 521-532, 1999.

OSÓRIO, C.M.; QUEIROZ, A.B.Z. Representações sociais de mulheres sobre a amamentação: teste de associação livre de ideias acerca da interrupção precoce do aleitamento materno exclusivo. Esc. Anna Nery Rev. Enferm, v. 11, n. 2, p. 261-267, 2007.

OZONOFF, D. et al. Health Problems reported by residents of a neighborhood contaminated by a hazardous waste facility. In: American Journal of Medicine, v. 11, pp.581 - 597, 1987.

PALLONI, A. Reproducing inequalities: luck, wallets, and the enduring effects of childhood health. Demography;43(4):587-615, 2006.

PAUliLO, M. A. S. A Pesquisa Qualitativa e a História de Vida. 2008. Disponivel em:http://www.ssrevista.uel.br/c_v2n1_pesquisa.htm. Acesso em: 14 de agosto de 2013.

PEDROSO, G.C. et al. Prevalência de aleitamento materno e introdução precoce de suplementos alimentares em área urbana do Sudeste do Brasil, Embu, SP. Rev Bras Saude Matern Infant.; 4: 45-58, 2004. 
PEREIRA, NETO. J.T. Gerenciamento do Lixo Urbano: as- pectos técnicos e operacionais. Viçosa: Ed. UFV; 2007.

PÉREZ-ESCAMILLA, R. Patrones de la lactancia natural en América Latina y el Caribe. Bol of Sanit Panam; 115:185-93, 1993.

PESSINI, L.A. Espiritualidade interpretada pelas ciências e pela saúde. Mundo da Saúde (1995).;31(2):187-95, 2007.

POLI, L.M.C. O processo de aleitamento materno na perspectiva do cuidado cultural de enfermagem. Curitiba, Dissertação (Mestrado em Assistência de Enfermagem). Universidade Federal de Santa Catarina/Universidade Federal do Paraná, 2000.

POPKIN, B.M. et al. Breast-feeding and diarrheal morbidity. Pediatrics,; 86:874-82. 3, 1990.

PONTES, C.A.A.; SCHRAMM, F.R. Bioética da proteção e papel do Estado: problemas morais no acesso desigual à água potável. Cadernos de Saúde Pública, Rio de Janeiro, v. 20, n. 5, p. 1319- 1327, 2004.

PORTO, M. F. S. et al. F. Lixo, trabalho e saúde: um estudo de caso com catadores em um aterro metropolitano no Rio de Janeiro, Brasil. Caderno Saúde Pública,20(6)1503-1514, 2004.

PREFEITURA DE ARAPIRACA. Relatório de Atividade de Educação Ambiental, 2007.

PRAÇA, N.S.; GUALDA, D.M.R. Cuidar da saúde da família: responsabilidade da mulher moradora em uma favela. Fam Saúde Desenv: 2(1)13-20, 2000.

QUEIROZ, L.L.C. et al.. Cobertura vacinal do esquema básico para o primeiro ano de vida nas capitais do Nordeste brasileiro in. Cad. Saúde Pública, v. 29, n. 2, p. 294-302, 2013.

QUINN, P.J. et al. The effect of breastfeeding on child development at 5 years: a cohort study. J Paediatr Child Health.;37(5):465-9, 2001.

RAMOS, C.V.; ALMEIDA, J.A.G. Alegações maternas para o desmame: estudo qualitativo. J Pediatr; 79(5):385-90, 2003.

REGO, R.C.F.; BARRETO, M.L.; KILLINGER, C.L. O que é lixo afinal? 
Como pensam as mulheres residentes na periferia de um grande centro urbano. Cad Saúde Pública novembro- dezembro; 18(6):1583-92, 2002.

RICHARDS, M.; HARDY, R.; WOODSWORTH, M.E. Long-term effects of breastfeeding in a national birth cohort educational attainment and middle cognitive functions. Public health Nutrition.;5(5):631-635, 2002.

ROSA, A.S.; CAVICCHIOLI, M.G.S.; BRÊTAS, A.C.P. O processo saúdedoença-cuidado e a população em situação de rua. Rev Latino-am Enfermagem julho-agosto; 13(4):576- 82, 2005.

RUEL, M.T.; MENON, P. Child feeding practices are associated with child nutritional status in Latin America: Innovative uses of the demographic and health surveys. J. Nutr., v.132, n.6,p.1180-7, . Disponível em: < http://bases.bireme.br/cgibin/wxislind.exe/iah/online/> Acesso em: 25 ago.2011. 2002 .

SACKER, A. et al. Breastfeeding and developmental delay: findings from the millennium cohort study. Pediatrics. 682-9, 2006:

SCHRAMM, F.R. Bioética da proteção: ferramenta válida para enfrentar problemas morais na era da globalização. Revista Bioética, Brasília, v. 16, p. 11-23, 2008.

SCHACK-NIELSEN, L.; MICHAELSEN, K.F. Breast feeding and future health. Curr Opin Clin Nutr Metab Care.;9(3):289-96, 2006.

SCHEPER-HUGHES, N. Death Without Weeping: The Violence of Everyday Life in Brazil. University of Cali- fornia Press: Berkeley, 1992.

SALVE, J.M.; SILVA, I.A. Representações sociais de mães sobre a introdução de alimentos complementares para lactentes. Acta Paul emf,22(1):43-8, 2009.

SANTOS, O.G; SILVA, F.F. Os significados do lixo para garis e catadores de Fortaleza (CE, Brasil). Ciênc. saúde coletiva [online]. 2011, vol.16, n.8, pp. 3413-3419. ISSN 1413-8123. http://dx.doi.org/10.1590/S1413$\underline{81232011000900008,2011 .}$

SANTOS, L.M.P. et al. The precarious livelihood in waste dumps: A report on food insecurity and hunger among recyclable waste collectors Rev. Nutr., Campinas, 26(3):323-334, maio/jun., 2013. 
SELLEN, D.W. Evolution of infant and young child feeding: implications for contemporary public health. Annual Review of Nutrition 27, 123-148, 2007.

SEPÚLVEDA, D. et al. Lactância materna: alguns fatores psicosociales y biológicos que la influenciam. Bol. Of. Sanit. Panam., v. 95, n. 1, p. 51-9, 1983.

SERRUYA, S. Mulheres Esterilizadas: Submissão e Desejo. Belém: Núcleo de Altos Estudos Amazônicos, Universidade Federal do Pará/Universidade do Estado do Pará, 1996.

SHIMODA, G.T.; SILVA, I.A. Necessidades de saúde de mulheres em processo de amamentação. Revista Brasileira de Enfermagem (Impresso), v. 63-1, p. 58-65, 2010.

SILVA, I. A. A vivência de amamentar para trabalhadoras e estudantes de uma universidade pública. Rev. bras. enferm, vol.58, n.6, pp. 641-646, 2005.

SILVA, I.A. Amamentação: fardo ou desejo? Estudo histórico-social dos saberes sobre aleitamento na sociedade brasileira. Ribeirão Preto,. 302 p. Dissertação (Mestrado) - Faculdade de Medicina de Ribeirão Preto, Universidade de São Paulo, 1990.

SILVA, I.A. Amamentar: uma questão de assumir riscos ou garantir benefícios [tese]. São Paulo(SP). Escola de Enfermagem USP;1994.

SILVA, I.A. Amamentar: uma questão de assumir riscos ou garantir benefícios. São Paulo: Robe Editorial; 1997.

SILVA, S.R.; GONÇALVES, M.A. O trabalho no lixo: o caso da associação dos trabalhadores catadores de resíduos sólidos recicláveis do município de Nova Andradina- MS. In: XII Encontro de Geógrafos da América Latina. Disponível em http://egal.easyplanners.info. Acesso em 11 de junho de 2011. Montevideo, 2009.

SILVA, S.M.C. et al. Prevalência de sorologia positiva para o HTLV-1 E HTLV-2 em Gestantes atendidas em três serviços públicos de pré-natal, São Luis, jul/08 a jul/09. Cadernos de Pesquisa, v. 16, n. 3, 2010.

SILVA, M.O.S. O Bolsa Família: problematizando questões centrais na política de transferência de renda no Brasil. Ciência \& Saúde Coletiva, Rio de Janeiro, v. 12, n. 6, p. 1429-1439, 2007. 
SILVEIRA, F.J.F.; LAMOUNIER, J.A. Prevalência do aleitamento materno e prática de alimentação complementar em crianças com até 24 meses de idade na região do Alto Jequitinhonha, Minas Gerais. Rev Nutr.;17:437-47, 2004.

SIMON, V.G.N, SOUZA, J.M.P, SOUZA, S.B. Introdução de alimentos complementares e sua relação com variáveis demográficas e socioeconômicas, em crianças nascidas no primeiro ano de vida, nascidas em Hospital Universitário no município de São Paulo. Rev bras epidemiol; 6(1):29-38, 2003.

SIQUEIRA-BATISTA, R.; SCHRAMM, F. R. A saúde entre a iniquidade e a justiça: contribuições da igualdade complexa de Amartya Sen. Ciência \& Saúde Coletiva, Rio de Janeiro, v. 10, n. 1, p.129-142, 2005.

SOARES, N.M.V.; SCHOR, N. Perfil de mulheres com alta fecundidade em um grande centro urbano no Brasil. Ciência \& Saúde Coletiva, v. 18, n. 4, p. 1041-1050, 2013.

SOUZA, M.H.N. A mulher que amamenta e suas relações sociais: uma perspectiva compreensiva de promoção e apoio [tese]. Rio de Janeiro: Escola de Enfermagem Anna Nery, UFRJ; 2006.

SOBRAL, A.; FREITAS, C. M. Modelo de organização de indicadores para operacionalização dos determinantes socioambientais da saúde. Saúde e Sociedade, São Paulo, v. 19, n. 1, p. 35-47, 2010.

STUEBE, A. The risks of not breastfeeding for mothers and infants. Rev Obstet Gynecol.;2(4):222-31, 2009.

SKAFIDA, V. Breastfeeding duration: The impact of maternal education and employment. SPA conference 2009; . working paper, 2009.

THAPA, et al. Breast feeding, birth spacing and their effects on child survival. Nature.;335(6192):679-82, 1988.

TOMA, T.S.; REA, M.F. Benefícios da amamentação para a saúde da mulher e da criança: um ensaio sobre as evidências. Cad Saúde Pública; 24 Suppl 2:S235-46, 2008.

TOMELERI, R.K; MARCON, S.S. Práticas populares de mães adolescentes no cuidado aos filhos. Acta Paul Enferm, v. 22, n. 3, p. 272-80, 2009. 
TRIVIÑOS, A.N.S. Introdução à pesquisa. em ciências sociais: a pesquisa qualitativa em educação. São Paulo, Atlas, 1992.

TUDISCO, E. S. et al. Avaliação do estado nutricional materno e duração do aleitamento natural. Revista de Saúde Pública, 18: 313-322, 1984.

UNITED NATIONS CHILDREN'S FUND (UNICEF). Situação Mundial da Infância 2008. Saúde Materna e Infantil. Brasília: UNICEF; 166p, 2008.

UNITED NATIONS CHILDREN'S FUND (UNICEF). Tracking progress on child and maternal nutrition: a survival and de- velopment priority. New York: United Nations Chil- dren's Fund; 2009.

UNITED NATIONS CHILDREN'S FUND (UNICEF). Avanços e Desafios: A Redução da Mortalidade Infantil em Alagoas/[coordenaçãogeral. Cristina Albuquerque e Jane Santos]. -Brasília, DF: UNICEF, 2012.

VASCONCELOS, M.G.L.; LIRA, P.I.C.; LIMA, M.C. Duração e fatores associados ao aleitamento materno em crianças menores de 24 meses de idade no estado de Pernambuco. Ver. Bras Saúde Mateno Infantil; 6:99-105, 2006.

VELLOSO, P.M. Os catadores de lixo eo processo de emancipação social; Waste material pickers and emancipation process. Ciênc. saúde coletiva, v. 10, n. supl, p. 49-61, 2005.

VELLOSO, M.P.; VALADARES, J.C.; SANTO, E.M. A coleta de lixo domiciliar na cidade do rio de janeiro: um estudo de caso baseado na percepção do trabalhador. Cien Saúde Coletiva 3(2):143-150, 1998;

VENÂNCIO, S.I.; MONTEIRO, C.A. A tendência da prática da amamentação no Brasil nas décadas de 70 e 80. Rev Bras Epidem; 1(1): 409, 1998.

VENANCIO, S.I.; ESCUDER, M.M.L.; SALDIVA, S.R.D.M.; GIUGLIANI, E.R.J. A prática do aleitamento materno nas capitais brasileiras e Distrito Federal: situação atual e avanços. J. Pediatr. (Rio J.) [online]. vol.86, n.4, pp. 317-324. http://dx.doi.org/10.1590/S0021$75572010000400012 ., 2010$.

VICTORIA, C.G. et al. Evidence for protection by breast-feeding against infant deaths from infec- tious diseases in Brazil. Lancet; 2:319-22, 1987. 
VITZTHUM, V.J. Evolutionary models of women's reproductive functioning. Annual Review of Anthropol- ogy 37, 53-73, 2008.

WAGSTAFF, A. Pobreza y desigualdades en el sector de la salud. Revista Panamericana de Salud Publica, Washington, DC, v. 11, n. 5/6, p. 316-326, 2002.

WARKENTIN, S. et al. Duração e determinantes do aleitamento materno exclusivo entre crianças brasileiras menores de dois anos. Rev. Nutr., Campinas, 26(3):259-269, maio/jun., 2013.

WILHELM, V. Occupational safety at landfills. In: International Landfill Symposium, 2, Proceedings, Sardinia. Itália, 1989.

WORLD HEALTH ORGANIZATION. BREAST-FEEDING. The technical basis and recommendations for action. Geneva; 1993.

WORTHMAN, C.M. KUZARA J. Life history and the early origins of health differentials. American Journal of Human Biology 17, 95-112, (2005).

WORLD BANK. World Development Report 2000/2001:Attacking Poverty. New York: Oxford University Press; 2000.

WONDAFRASH, M.; AMSALU, T.; WOLDIE, M. Feeding styles of caregivers of children 6-23 months of age in Derashe special district, Southern Ethiopia. BMC Public Health, v. 12, n. 1, p. 235, 2012.

WORLD HEALTH ORGANIZATION. 54th World Health Assembly. Geneva; 2001.

ZANETII, C.B.B. As Sobras da modernidade. O sistema de gestão de resíduos sólidos em porto alegre, Rs. Porto Alegre: CORAG; 2006.

ZOLLNER, C. C; FISBERG, R.M. Estado nutricional e sua relação com fatores biológicos, sociais e demográficos de crianças assistidas em creches da Prefeitura do Município de São Paulo; São Paulo. Rev. bras. saúde matern. infant, v. 6, n. 3, p. 319-328, 2006. 
APÊEDICE 


\section{APÊNDICE A}

\section{Formulário de coleta de dados de identificação}

Data:

l 1

$\mathrm{N}^{\mathrm{o}}$ :

Hora:

A - Identificação materna

Nome:

Endereço:

Ponto de referência:

Data de nascimento: / / Idade:

Telefone (contato):

Informações sobre Trabalho e local:

Número de gestações

Abortos

Paridade Número de filhos vivos:

Idade do último filho Tipo de parto

Tempo e tipo de amamentação do(s) filho (s) 


\section{APÊNDICE B}

Termo de Consentimento Livre e Esclarecido

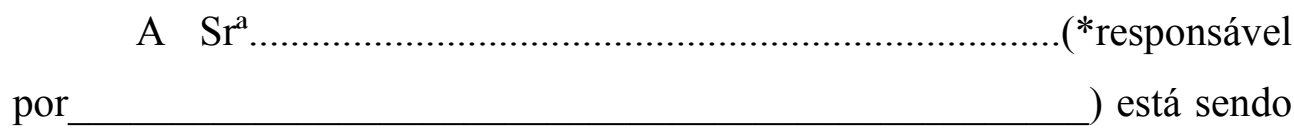

convidada a participar como voluntária do projeto de pesquisa "Significado de amamentar para mulheres residentes em uma comunidade de alta vulnerabilidade social no interior de Alagoas", de responsabilidade da pesquisadora Janaína Ferro Pereira, enfermeira e professora da Universidade Federal de Alagoas, responsável por sua execução e recebi delas as seguintes informações que me fizeram entender sem dificuldades e sem dúvidas os aspectos abaixo pontuados .

1) $\mathrm{O}$ estudo se destina mulheres que estão amamentando ou amamentaram e são moradoras da comunidade Mangabeiras;

2) A importância deste estudo está no fato de contribuir com informações que possam reconhecer a realidade vivenciada pelas mulheres ao amamentarem seus filhos;

3) O resultado que pretendemos alcançar é verificar o significado da amamentação para nós mulheres moradoras da comunidade da mangabeiras ;

4) O estudo será feito mediante entrevistas, realizadas na comunidade e nas residências

5) Eu participarei da entrevista;

6) A observação de minhas atitudes e comportamento será outro meio de se obter os resultados desta pesquisa;

7) Os incômodos que poderei sentir durante a minha participação são constrangimento com as perguntas;

8) Os riscos à minha saúde física e mental são mínimos;

9) $\mathrm{Eu}$ terei como benefício ser informada do resultado da minha contribuição e da pesquisa em geral;

10) Eu serei visitada em minha residência, onde será marcada a data e horário da entrevista;

11) Que, sempre que desejar serão fornecidos esclarecimentos sobre cada uma das etapas do estudo;

12) Que eu poderei, a qualquer momento, recusar a continuar participando do estudo e também a que eu poderei retirar este meu consentimento, sem que isso me traga nenhuma penalidade ou prejuízo;

13) Que as informações conseguidas através da minha participação no estudo não permitirão a identificação da minha pessoa, exceto pelos responsáveis, e que a divulgação das mencionadas informações só será feita entre os profissionais estudiosos do assunto;

14) Que eu deverei ser indenizado por qualquer despesa que venha a ter decorrente de minha participação neste estudo e, também, por quaisquer 
danos que venha a sofrer pela mesma razão, sendo que para essas despesas, foi-me garantida a existência de recursos.

Finalmente, tendo eu compreendido perfeitamente tudo o que me foi informado sobre a minha participação no mencionado estudo estando consciente dos meus direitos, das minhas responsabilidades, dos riscos e dos benefícios que a minha participação implicam, concordo em dele participar e para isso eu DOU O MEU CONSENTIMENTO SEM QUE PARA ISSO EU TENHA SIDO FORÇADO OU OBRIGADO.

Endereço do(a) participante-voluntário(a):

Domicílio: ( rua, praça, conjunto)

Bloco, $n^{\circ}$

\begin{tabular}{rr}
\hline Complemento: & Bairro: \\
CEP/cidade: & Telefone:
\end{tabular}

Ponto de Referência:

Endereço da responsável pela pesquisa:

Instituição: Universidade de São Paulo- EEUSP

Sr.(a): Janaína Ferro Pereira

Endereço: Rua Abdon Arroxelas, 680

Bairro: Ponta Verde Cidade:Maceió CEP: 57035380

FONE: (82)99203932

Endereço da orientadora responsável pela pesquisa:

Sr.(a): Isilia Aparecida da Silva

Endereço: Av. Dr. Enéas de Carvalho Aguiar, 419 Cidade: São

Paulo- SP CEP: 05403-000

FONE:

Endereço do Comitê de Ética:

Comitê de Ética em Pesquisa da EEUSP Instituição:

Endereço: edipesq@usp.br

Bairro: Av. Dr. Enéas de Carvalho Aguiar, 419 Cidade: São

Paulo- SP CEP: 05403-000

Fone: (11) 3061-7548

Observações importantes:

*Nos casos de participantes menores de 18 anos

1. Caso a participante tenha dificuldades para leitura e escrita, será

solicitada a presença de testemunha de sua escolha para acompanhar os

esclarecimentos e análise do termo a ser assinado.

2. Esse termo será elaborado em 2(duas) vias uma delas ficará com o entrevistado e a outra com o pesquisador.

Arapiraca, de de 2012.

Assinatura da voluntária

Assinatura da responsável pela entrevista 


\title{
Parecer consubstanciado do CEP
}

\author{
Plataforma Brasil - Ministerio da Saude
}

Escola de Enfermagem da Universidade de Sao Paulo - EEUSP

PROJETO DE PESQUISA

Titulo: Significado de amamentar para mulheres residentes em uma comunidade de alta Area Tematica: vulnerabilidade social no interior de Alagoas.

\author{
Pesquisador: Janalna F. Pereira \\ Versao: 2 \\ Instituiçao: Escola de Enfermagem da Universidade de Sao CAAE: $\quad$ 02002312.9.0000.5392 \\ Paulo - EEUSP
}

\section{PARECER CONSUBSTANCIADO DO CEP}

\section{Numero do Parecer: 39252 \\ Data da Relatoria: 19/06/2012}

\section{Apresentaçao do Projeto:}

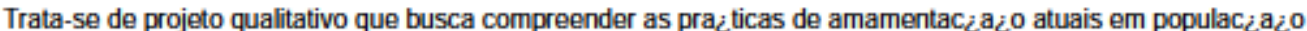
de alta vulnerabilidade. Pressupo ${ }_{\mathcal{L}}$ e-se que a adesa $a_{\mathcal{L}}$ de certos valores e comportamentos podem ou na $\mathrm{C}_{\mathcal{L}} \mathrm{O}$ contribuir para o sucesso no processo de aleitamento materno. Portanto, a possibilidade de uma crianc $\mathcal{L}_{\dot{L}}$ a ser amamentada passa tambe $\dot{ }$ m por pre $e_{\text {-requisitos que compo }}$ em o universo cultural de diferentes camadas sociais.

Crite rio de Inclusa 0 :

Mulheres moradoras da comunidade Mangabeira em tempo integral, ou seja, que morem na comunidade e que ao trabalharem fora da comunidade, retornem diariamente para casa; que estejam amamentando ou tenham amamentado seu filho por qualquer tempo desde que o desejem e aceitem sua participac ${ }_{\llcorner} a_{\llcorner} 0$ no estudo.

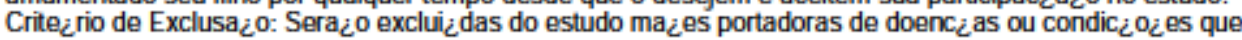
impossibilitem a amamentac $\mathrm{a}_{\dot{C}} \mathrm{O}$.

Sera $a_{\mathcal{C}}$ utilizado como referencial teo ¿rico o Interacionismo Simbo ¿lico, que sustenta-se na busca de significados para os sujeitos em meio a uma realidade de vida que pode estar carregada de simbolismos que permeiam as

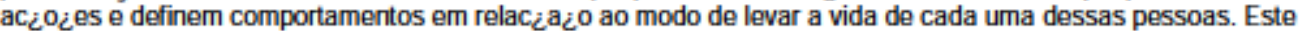
referencial desenvolve um esquema analiztico da sociedade e das condutas humanas, que ernvolve ideias ba $a_{\mathcal{C}}$ sicas relacionadas a grupos humanos ou sociedades, interac ${ }_{\mathcal{C}} \mathrm{a}_{\mathcal{L}} \mathrm{O}$ social, objetos, o ser humano como ator, a ac $_{\mathcal{L}} \mathrm{a}_{\mathcal{L}} \mathrm{o}$ humana $\mathrm{e}$ as interconexo ${ }_{\mathcal{L}}$ es das linhas de $\mathrm{ac}_{\mathcal{L}} \mathrm{a}_{\mathcal{L}} \mathrm{O}$.

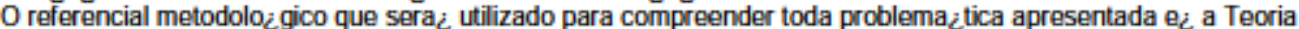
Fundamentada nos Dados, que se relaciona com o Interacionismo Simbo ¿lico, pois tem como foco o estudo do comportamento humano em seus aspectos experienciais e de ac $a_{\mathcal{L}} \mathrm{a}_{\mathcal{L}} \mathrm{o}$ em seu contexto, utilizando seus pressupostos como referencial.

Inicialmente sera ${ }_{\mathcal{L}}$ realizadas visitas na comunidade com a finalidade de identificar as mulheres que $\mathrm{sa}_{\mathcal{L}} \mathrm{O}$ potencialmente sujeitos do estudo. Sera ${ }_{\mathcal{L}}$ feita uma visita a nutriz, e na primeira visita domiciliar o objetivo sera $a_{\mathcal{L}}$

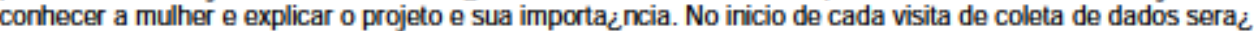

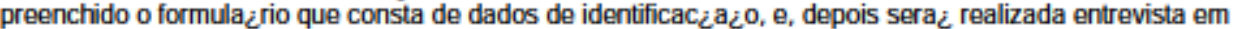
profundidade, para abordagem qualitativa. Esta $\_$o previstos 10 sujeitos para o estudo.

\section{Objetivo da Pesquisa:}

Objetivo Primajrio:

Compreender o significado de amamentar, como se deservolve o processo de decisa $a_{\mathcal{L}}$ sobre amamentac ${ }_{\dot{L}} \mathrm{a}_{\mathcal{L}} \mathrm{O}$ e desenvolver modelo teo ¿ rico representativo da experie ¿ncia de amamentar, entre mulheres moradoras de comunidade com alta vulnerabilidade social, no interior do estado de Alagoas.

Objetivo Secunda zrio:

Compreender o significado de amamentar para estas mulheres - Como se desenvolve o processo de decisa $a_{i}$

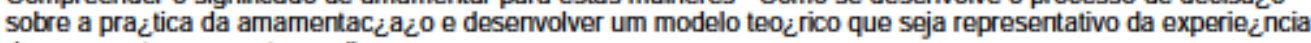
de amamentar para estas mulheres

Avaliaçao dos Riscos e Beneficios: os riscos e benefi $i_{\mathcal{L}}$ cios foram adequadamente ponderados e permitem a realizac ${ }_{\mathcal{L}} \mathrm{a}_{\mathcal{L}} \mathrm{O}$ da pesquisa.

Comentarios e Consideraçoes sobre a Pesquisa: 